'

2010 Groundwater Monitoring and Inspection Report Gnome-Coach Site, New Mexico

February 2011

Approved for public release; further dissemination unlimited

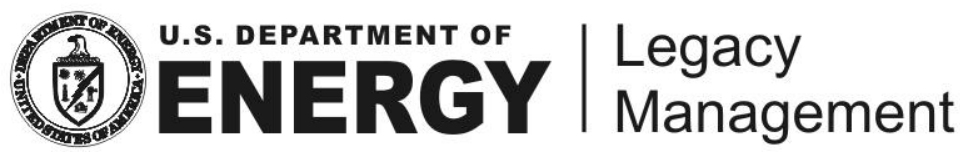


Available for sale to the public from:

U.S. Department of Commerce

National Technical Information Service

5301 Shawnee Road

Alexandria, VA 22312

Telephone: 800.553.6847

Fax: 703.605.6900

E-mail: orders@ntis.gov

Online Ordering: http://www.ntis.gov/help/ordermethods.aspx

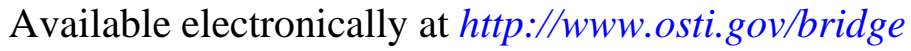

Available for a processing fee to U.S. Department of Energy and its contractors, in paper, from:

U.S. Department of Energy

Office of Scientific and Technical Information

P.O. Box 62

Oak Ridge, TN 37831-0062

Phone: 865.576 .8401

Fax: 865.576.5728

Email: reports@adonis.osti.gov

Reference herein to any specific commercial product, process, or service by trade name, trademark, manufacturer, or otherwise, does not necessarily constitute or imply its endorsement, recommendation, or favoring by the United States Government or any agency thereof or its contractors or subcontractors. 


\title{
2010 Groundwater Monitoring and Inspection Report Gnome-Coach Site, New Mexico
}

\author{
February 2011
}

Approved for public release; further dissemination unlimited 
This page intentionally left blank 


\section{Contents}

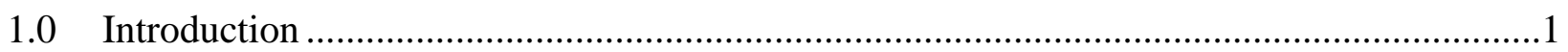

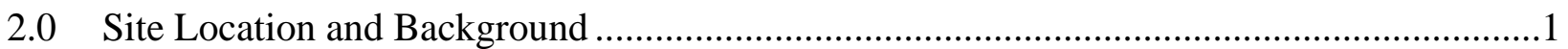

2.1 Summary of Reclamation and Remediation Activities ................................................

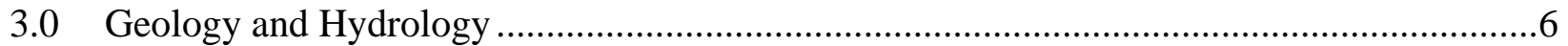

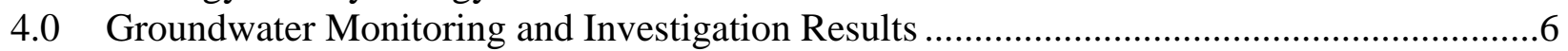

4.1 Geophysical Well Logging and Results ..................................................................

$4.2 \quad$ Hydraulic Head Monitoring and Results ....................................................................

4.3 Groundwater Sampling and Results .....................................................................

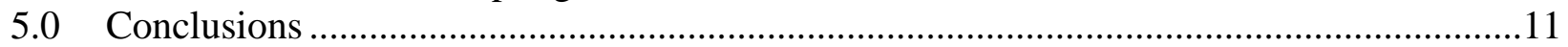

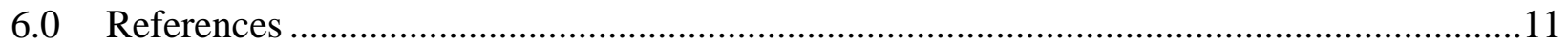

\section{Figures}

Figure 1. Gnome Site Location Map..................................................................................... 2

Figure 2. LTHMP Sampling Locations in 2009 ..................................................................... 3

Figure 3. Hydrograph Showing Water Elevations in Wells USGS-1, USGS-4, and USGS-8 ....... 9

Figure 4. Hydrograph Showing Water Elevations in Well LRL-7 ................................................. 9

\section{Tables}

Table 1. LTHMP Sample Locations: 1972 to 2009.................................................................... 5

Table 2. Geophysical Well Logs, Wells USGS-1, USGS-4, and USGS-8....................................... 7

Table 3. Gnome Site Water Levels .......................................................................................... 8

Table 4. Gnome Site Groundwater Sample Analytical Results ................................................... 10

\section{Appendixes}

Appendix A COLOG Well Logs and Eastman Deviation Data-USGS-8

Appendix B Well Concentration Plots 
This page intentionally left blank 


\subsection{Introduction}

This report presents the 2010 groundwater monitoring results collected by the U.S. Department of Energy (DOE) Office of Legacy Management (LM) at the Gnome-Coach (Gnome) Site in New Mexico (Figure 1). Groundwater monitoring consisted of collecting hydraulic head data and groundwater samples from the wells on site. Historically, the U.S. Environmental Protection Agency (EPA) had conducted these annual activities under the Long-Term Hydrologic Monitoring Program (LTHMP). LM took over the sampling and data collection activities in 2008 but continues to use the EPA Radiation and Indoor Environments National Laboratory in Las Vegas, Nevada, to analyze the water samples. This report summarizes groundwater monitoring and site investigation activities that were conducted at the site during calendar year 2010.

\subsection{Site Location and Background}

The Gnome Site consists of 640 acres of federally withdrawn lands approximately 25 miles east of Carlsbad in Eddy County, New Mexico (Figure 1). The site was the location of the first underground nuclear test performed under the Plowshare Program by the U.S. Atomic Energy Commission, predecessor to DOE. The Plowshare Program was a research and development initiative started in 1958 to determine the technical and economic feasibility of peaceful applications of nuclear energy. The underground nuclear test conducted at the Gnome Site was identified as Project Gnome and was performed on December 10, 1961. The test consisted of detonating a nuclear device with an estimated yield of 3 kilotons at a depth of 1,184 feet (ft) below ground surface (bgs) in a bedded salt deposit known as the Salado Formation. Immediately following the detonation, close-in stemming materials failed, and gasses from the cavity vented to the atmosphere through the access shaft and tunnel (Rawson et al. 1964). Post-test drilling operations and preparations for another underground nuclear test, identified as Coach, began shortly after the Project Gnome test. The Coach experiment was initially scheduled for 1963 but was canceled and never executed.

No additional underground nuclear detonations occurred at the Gnome Site; however, in 1963, the U.S. Geological Survey (USGS) conducted a groundwater tracer test using four dissolved radionuclides - tritium, iodine-131, strontium-90, and cesium-137-as tracers. The tracer test was conducted between wells USGS-4 and USGS-8 located west of the blast point, the surface projection of which is surface ground zero (SGZ) (Figure 2). Wells USGS-4 and USGS-8 are completed in the Culebra Dolomite Member of the Rustler Formation that lies above the Salado Formation. The Culebra Dolomite is a fractured carbonate aquifer of Permian age and is considered the most prolific aquifer near the Gnome Site. For this reason, the Culebra aquifer is considered a critical transport pathway, not only for radionuclides used in the tracer test, but also for any detonation-related radionuclides that might be released to groundwater. 


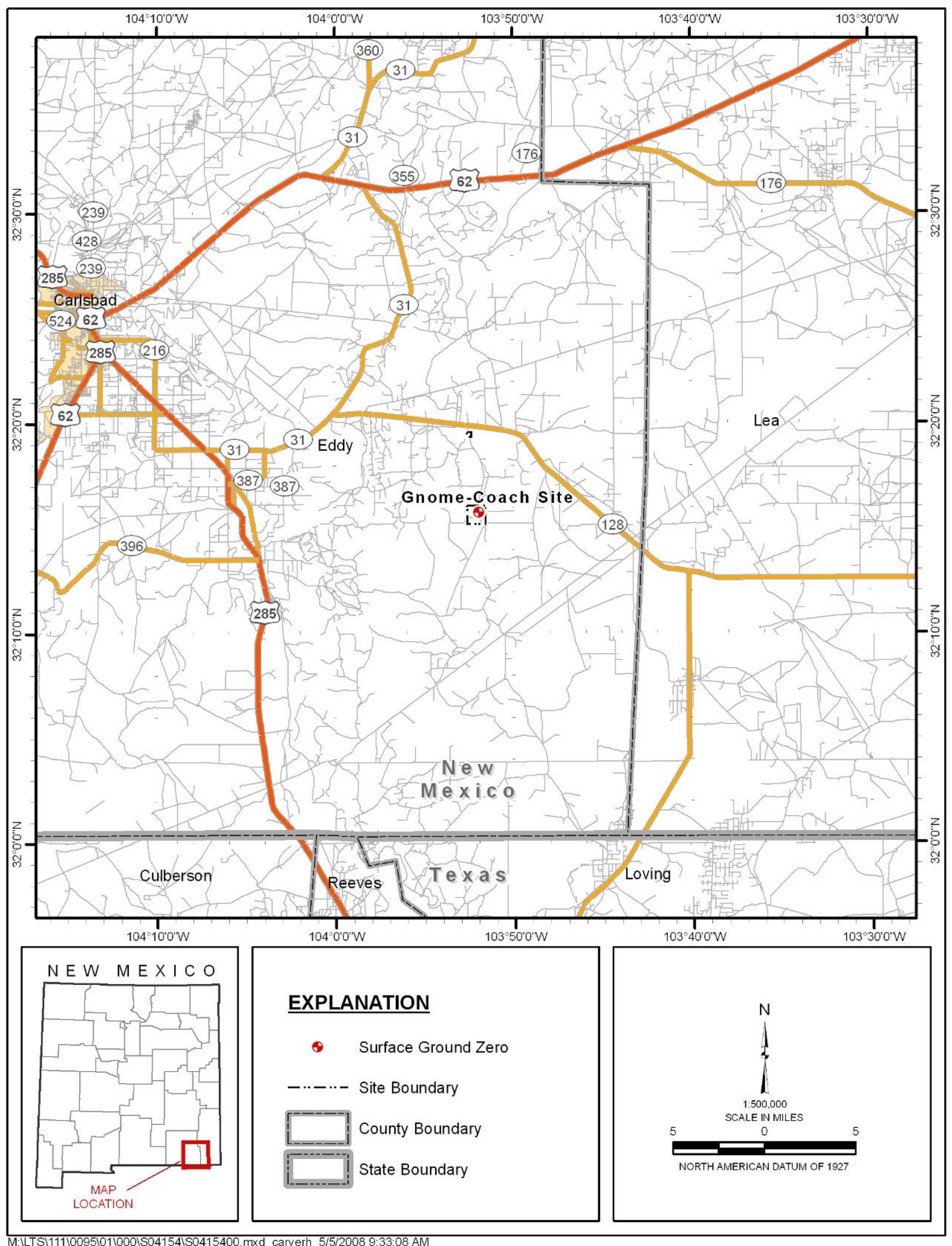

Figure 1. Gnome Site Location Map 


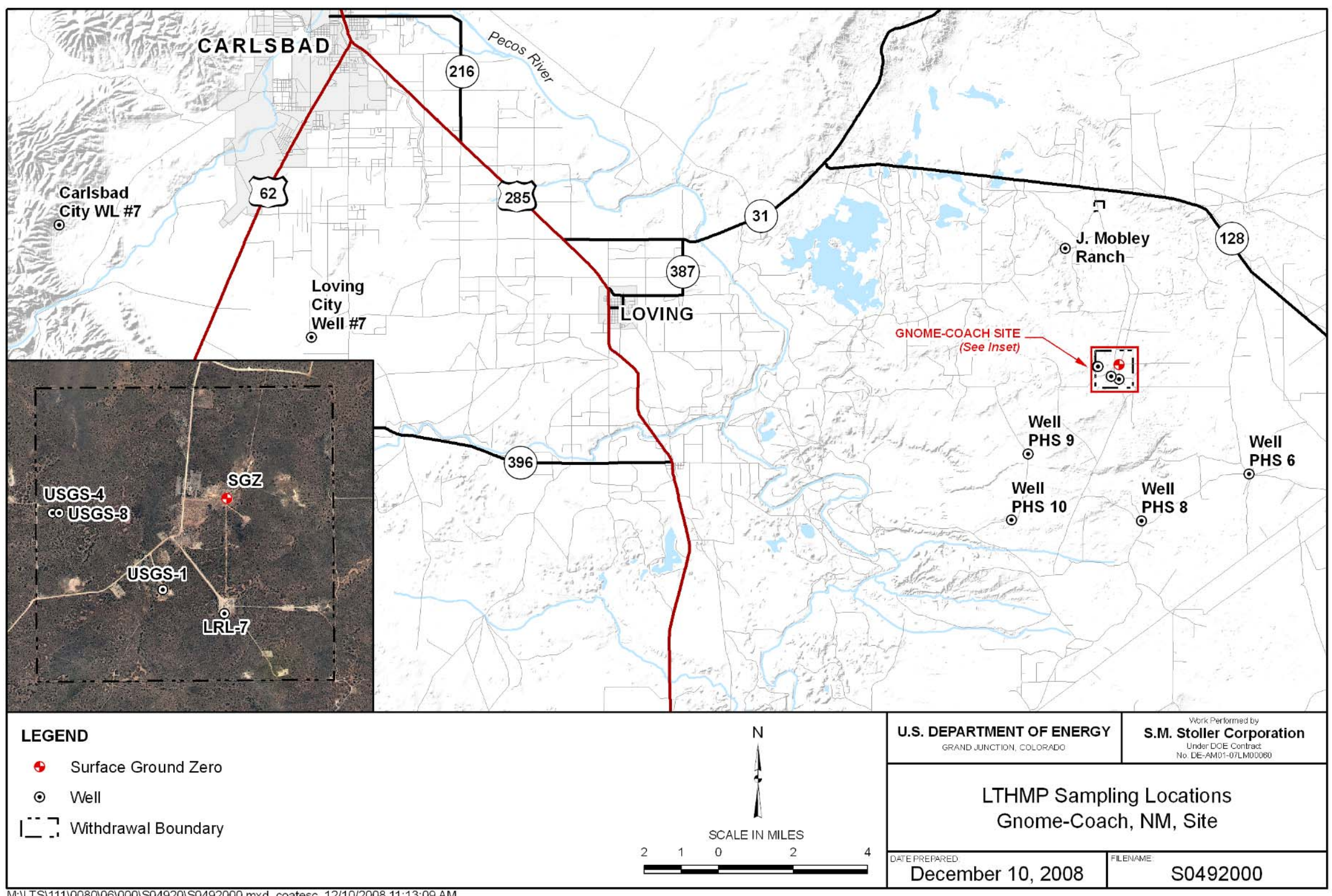

Figure 2. LTHMP Sampling Locations in 2009 


\subsection{Summary of Reclamation and Remediation Activities}

Surface and subsurface contamination resulted from the underground nuclear testing, post-test drilling, and groundwater tracer test performed at the Gnome Site. The original cleanup associated with the site was conducted between 1968 and 1969. During this phase of the cleanup, radioactive sludge from holding tanks and liquid from evaporation ponds were pumped into the test cavity, contaminated equipment and solid waste were disposed of in the emplacement shaft, uncontaminated buildings and equipment were moved off site, and drill holes were plugged except those retained for the LTHMP (REECO 1981). In 1972, an area reconnaissance revealed that cover material over a waste dump that remained from the post-test drilling operations was eroding and exposing contaminated material. The second major cleanup was conducted from 1977 to 1979 and included excavating contaminated soils from the waste dump and burying them in the emplacement shaft, removing concrete pads, performing general housekeeping activities, and conducting extensive post-cleanup sampling. During these operations, the test cavity and horizontal tunnel were filled to capacity, and remaining contaminated material was transported to the Nevada National Security Sites formerly the Nevada Test Site (REECO 1981).

In 1994, radiological contamination was identified on the surface and in the shallow subsurface (depth of $20 \mathrm{ft}$ bgs) during a survey and sampling event conducted by EPA. The DOE National Nuclear Security Administration (NNSA) Nevada Site Office conducted a corrective action investigation to assess the extent of contamination detected at the site. The field investigation was performed from February through June 2002 and in May 2003. Soil samples were collected and analyzed for radiological and chemical constituents. Analytical results indicated concentrations of total petroleum hydrocarbons diesel-range organics at concentrations that exceeded the State of New Mexico Clean-up Standards. The hydrocarbon contaminated soil was excavated and removed for disposal as part of the corrective action. The Corrective Action Investigation Report (DOE/NNSA 2004) for the Gnome Site summarizes the results of the investigation. After discussions with the State of New Mexico, it was decided that the site would be administered under the Voluntary Remediation Program. A Completion Report, prepared in accordance with the Voluntary Remediation Program, recommended no further corrective actions, no use restrictions for the surface at the Gnome Site, and the eventual goal of clean closure (DOE/NNSA 2005). The State of New Mexico is currently proceeding with a conditional certificate of completion for the surface at the Gnome Site.

Subsurface corrective action activities have been limited at the site and have generally consisted of annual sampling and monitoring of groundwater as part of the LTHMP. The LTHMP began in 1972 and was performed by EPA until 2008. The purpose of the LTHMP was to ensure public safety, inform the public and news media, and document compliance with state and federal requirements (EPA 1972). The initial planning document for the program included the collection of samples from 11 locations, three of which were on site. Since 1972, locations used for longterm sampling have changed; some locations were abandoned or replaced, and new locations have been added. Samples collected from these locations have generally been analyzed for gamma-emitting radionuclides (using high-resolution gamma spectrometry), strontium-90, and tritium (using conventional and electrolytic enrichment methods). Table 1 shows well sample location information, including the distance and direction from SGZ, the formation monitored, and the year sampling began. 
Table 1. LTHMP Sample Locations: 1972 to 2009

\begin{tabular}{|c|c|c|c|c|}
\hline $\begin{array}{l}\text { Sample } \\
\text { Location }\end{array}$ & $\begin{array}{c}\text { Distance and } \\
\text { Direction from SGZ }\end{array}$ & $\begin{array}{l}\text { Formation/Unit } \\
\text { Monitored }\end{array}$ & $\begin{array}{c}\text { First Year of } \\
\text { Sampling }\end{array}$ & Comments \\
\hline USGS-1 & $2,250 \mathrm{ft}$ southwest & Culebra Dolomite & 1972 & $\begin{array}{l}\text { Completed with pump and } \\
\text { used by ranchers for livestock. }\end{array}$ \\
\hline USGS-4 & $3,180 \mathrm{ft}$ west & Culebra Dolomite & 1972 & Used in the 1963 tracer test. \\
\hline USGS-8 & $3,060 \mathrm{ft}$ west & Culebra Dolomite & 1972 & Used in the 1963 tracer test. \\
\hline PHS-6 & 4.6 miles southeast & Gatuna Formation & 1972 & $\begin{array}{l}\text { Completed with pump and } \\
\text { used by ranchers for livestock. }\end{array}$ \\
\hline PHS-8 & 4.3 miles south & Rocks of Triassic age & 1972 & $\begin{array}{l}\text { Completed with pump and } \\
\text { used by ranchers for livestock. }\end{array}$ \\
\hline PHS-9 & 3.5 miles southwest & Gatuna Formation & 1972 & $\begin{array}{l}\text { Completed with pump and } \\
\text { used by ranchers for livestock. }\end{array}$ \\
\hline PHS-10 & 5.15 miles southwest & Culebra Dolomite & 1972 & $\begin{array}{l}\text { Completed with pump and } \\
\text { used by ranchers for livestock. }\end{array}$ \\
\hline DD-1 & $285 \mathrm{ft}$ south & Salado Formation & 1981 & $\begin{array}{l}\text { Reentry well drilled into the } \\
\text { detonation cavity. Last sampled } \\
\text { in } 2005 \text {. }\end{array}$ \\
\hline LRL-7 & $2,370 \mathrm{ft}$ south & Salado Formation & 1981 & $\begin{array}{l}\text { Drilled into a shaft } \\
\text { constructed for the Coach } \\
\text { underground test. }\end{array}$ \\
\hline J. Mobley Ranch & 3.4 miles north-northwest & Unknown & 1993 & $\begin{array}{l}\text { Well screen interval and } \\
\text { completion depth unknown. } \\
\text { May monitor Culebra Dolomite. }\end{array}$ \\
\hline $\begin{array}{l}\text { Carlsbad City } \\
\text { Well No. } 7\end{array}$ & 28.7 miles west & Capitan Limestone & 1972 & $\begin{array}{l}\text { Completed with pump. Used as } \\
\text { a City supply well. }\end{array}$ \\
\hline $\begin{array}{l}\text { Loving City } \\
\text { Well No. } 7\end{array}$ & 21.7 miles west & Capitan Limestone & 2006 & $\begin{array}{l}\text { Well screen interval and } \\
\text { completion depth unknown. } \\
\text { Used as a City supply well. }\end{array}$ \\
\hline $\begin{array}{l}\text { Loving City } \\
\text { Well No. } 2\end{array}$ & 13.2 miles west & Capitan Limestone & 1972 & Well plugged in 2005. \\
\hline $\begin{array}{l}\text { Malaga City Tap } \\
\text { Water }\end{array}$ & 12.2 miles west & Piped from Loving & 1972 & Last sampled in 1976. \\
\hline \begin{tabular}{|l|} 
Pecos River \\
Pumping Station \\
Well No. 1 \\
\end{tabular} & 15 miles south-southeast & $\begin{array}{l}\text { Undifferentiated rocks } \\
\text { of Tertiary and } \\
\text { Quaternary age }\end{array}$ & 1972 & Last sampled in 1992. \\
\hline
\end{tabular}

Responsibility for the Gnome Site was transferred from the DOE Office of Environmental Management to LM on October 1, 2006. After the transfer, LM evaluated the LTHMP and associated monitoring network. The purpose of the evaluation was to determine the effectiveness of the current monitoring network and determine future monitoring at the site. The evaluation considered feasible pathways for contaminant migration from the detonation zone and tracer test to surrounding receptors. Analytical results from more than 30 years of monitoring indicate that groundwater at sample locations outside the land-withdrawal boundary (Figure 1) were not impacted by nuclear-test-related contamination. For this reason, locations outside the landwithdrawal boundary have been excluded from future sampling, but wells within and near the boundary will continue to be monitored. LM installed pressure transducers in the on-site monitoring wells to obtain hydraulic head data for continued evaluation of the site. Results of the hydraulic head monitoring are provided in Section 4.2. 


\subsection{Geology and Hydrology}

The Gnome Site is in the northwestern part of the Delaware Basin, a deep oval sedimentary basin 75 miles wide and 135 miles long in southeastern New Mexico. The geology and hydrology of this basin are well studied because of oil and gas exploration, mining, and the extensive studies required to locate the Waste Isolation Pilot Plant approximately 8 miles north-northeast of the Gnome Site. The basin deposits dip gently to the east and southeast, though in places the bedding is almost flat. During the late Permian Period, a warm shallow sea in the region provided ideal environments for reef development, which blocked seawater circulation. As the seawater began to evaporate, brines were formed, and crystalline salts precipitated and accumulated on the basin floor. As a result, the Gnome Site area is underlain by several thousand feet of limestone, dolomite, gypsum, halite, anhydrite, and potassium salts (potash). The Salado Formation, in which the Gnome detonation took place, is a 2,500-ft-thick bed of halite that formed during the Permian Period. The Salado Formation is virtually impermeable due to the plastic nature of the salt under pressure.

Overlying the Salado Formation are five thin-bedded members of the Rustler Formation. This formation includes the Culebra Dolomite Member, which was the subject of extensive study during the location and siting phases of the Waste Isolation Pilot Plant. Above the Culebra Dolomite is the Tamarisk Anhydrite Member, which is overlain by the Magenta Dolomite. The uppermost member of the Rustler Formation is the Forty-Niner Member, a mixture of gypsum and anhydrite. The youngest Permian sequences in the Gnome Site area are the thin, red, sedimentary rocks of the Dewey Lake Redbeds. At the Gnome Site, about $200 \mathrm{ft}$ of Permian-age anhydrites, mudstones, and dolomites separate the Culebra Dolomite from younger overlying formations.

The Culebra Dolomite is a widespread, laterally continuous, fractured carbonate aquifer that is approximately $30 \mathrm{ft}$ thick and is encountered approximately $490 \mathrm{ft}$ bgs at the Gnome Site. The groundwater within the Culebra generally moves through fractures and is of poor quality because of high concentrations of dissolved solids (Mercer 1983). The Culebra is the most prolific aquifer near the Gnome Site, and despite the poor water quality it is a source of water for ranchers maintaining livestock throughout the area.

\subsection{Groundwater Monitoring and Investigation Results}

Groundwater monitoring and site investigation activities conducted in 2010 consisted of geophysical well logging, hydraulic head monitoring, and groundwater sampling. Results obtained from these activities are summarized in the following sections.

\subsection{Geophysical Well Logging and Results}

COLOG Well Services conducted geophysical well logging on April 7 and 21, 2010, at wells USGS-1, USGS-4, and USGS-8. The well logging included borehole deviation, downhole video, and gamma-ray logging. The data were acquired to assist in the evaluation of these wells for continued monitoring. Table 2 provides the borehole geophysical techniques and approximate footage for the wells. 
Table 2. Geophysical Well Logs, Wells USGS-1, USGS-4, and USGS-8

\begin{tabular}{||l|c|c|c||}
\hline \multicolumn{1}{|c|}{ Geophysical Logs } & $\begin{array}{c}\text { Well USGS-1 } \\
\text { (ft) }\end{array}$ & $\begin{array}{c}\text { Well USGS-4 } \\
\text { (ft) }\end{array}$ & $\begin{array}{c}\text { Well USGS-8 } \\
\text { (ft) }\end{array}$ \\
\hline Video Log & Not Logged & 0 to 512 & 0 to 495 \\
\hline Deviation Survey & 0 to 500 & 0 to 512 & Not Logged $^{\text {a }}$ \\
\hline Gamma Log & Not Logged & 0 to 512 & 0 to 495 \\
\hline
\end{tabular}

${ }^{\mathrm{a}} \mathrm{A}$ deviation log was not obtained because previous data are available and are provided in Appendix $\mathrm{A}$ to this report.

COLOG acquired borehole deviation data from wells USGS-1 and USGS-4. A deviation survey was not conducted at well USGS-8 because deviation data were available from when the well was installed in 1963 (Appendix A). Wells USGS-1 and USGS-4 were logged on April 7, 2010. Well USGS-4 was re-logged on April 21, 2010 because data acquired from the logging on April 7 needed to be verified for horizontal direction. The deviation survey of well USGS-1 reached a measured depth of $500 \mathrm{ft}$ bgs, just above the pump. The survey indicates that the well deviates approximately 2.5 degrees from vertical with an offset in plan view of approximately $9 \mathrm{ft}$ northwest of the surface collar and that the measured depth of $500 \mathrm{ft}$ bgs is at a true vertical depth of $499.88 \mathrm{ft}$ bgs. The deviation survey for well USGS-4 reached a measured depth of $502.9 \mathrm{ft}$ bgs. The survey indicates that the well deviates approximately 15 degrees from vertical with an offset in plan view of approximately $60 \mathrm{ft}$ west of the surface collar and that the measured depth of $502.9 \mathrm{ft}$ bgs is at a true vertical depth of $496.46 \mathrm{ft}$ bgs (a 6.36-ft difference at this depth).

Gamma ray logs were acquired from wells USGS-4 and USGS-8 on April 7, 2010. Data obtained from these wells provide geologic information that can be correlated with other wells in the area and new wells as data become available. Elevated gamma ray counts (as high as 30,000 API units) were observed from 460 to $480 \mathrm{ft}$ bgs in well USGS-8 and are attributed to residual cesium-137 from the tracer test conducted by the USGS in 1963. Downhole video logs of wells USGS-4 and USGS-8 indicated that the casing in well USGS-4 was more corroded than the casing in well USGS-8, though the casings in both wells are in generally good condition for their age. The video logs are maintained in the LM project files in Grand Junction.

\subsection{Hydraulic Head Monitoring and Results}

Hydraulic head is monitored in the on-site wells USGS-1, USGS-4, USGS-8, and LRL-7. Depth to water was measured in wells USGS-1, USGS-4, USGS-8, and LRL-7 in January and April 2010. Monitoring was enhanced in April 2010 with the installation of a flow meter to measure flow rates from water supply well USGS-1 and with the installation of a pressure transducer in well DD-1. Table 3 presents the water level data and groundwater elevations obtained in 2010 with the zone of completion and unit monitored for the wells. 
Table 3. Gnome Site Water Levels

\begin{tabular}{|c|c|c|c|c|c|c|c|}
\hline Well & Date & $\begin{array}{l}\text { DTW } \\
\text { (ft) }^{a}\end{array}$ & $\begin{array}{c}\text { TOC } \\
\text { Elevation } \\
(\mathrm{ft})^{\mathrm{b}}\end{array}$ & $\begin{array}{c}\text { TSZ } \\
\text { Elevation } \\
(\mathrm{ft})^{\mathbf{b}}\end{array}$ & $\begin{array}{c}\text { BSZ } \\
\text { Elevation } \\
(\mathrm{ft})^{\mathbf{b}}\end{array}$ & $\begin{array}{l}\text { Formation/Unit } \\
\text { Monitored }\end{array}$ & $\begin{array}{c}\text { Groundwater } \\
\text { Elevation } \\
(\mathrm{ft})^{\mathrm{b}}\end{array}$ \\
\hline USGS-1 ${ }^{\mathrm{C}}$ & $01 / 26 / 2010$ & 434.30 & $3,425.78$ & $2,907.78$ & $2,875.78$ & Culebra Dolomite & $2,991.48$ \\
\hline USGS-4 & $04 / 07 / 2010$ & 426.72 & $3,415.25$ & $2,943.22$ & $2,909.70$ & Culebra Dolomite & $2,993.36$ \\
\hline USGS-8 & $04 / 06 / 2010$ & 419.30 & $3,412.96$ & $2,949.96$ & $2,917.96$ & Culebra Dolomite & $2,993.66$ \\
\hline LRL-7 & $04 / 06 / 2010$ & 459.00 & $3,442.42$ & $2,654.42$ & $2,128.42$ & Salado Formation & $2,983.42$ \\
\hline DD-1 & 04/06/2010 & NM & $3,398.18$ & NM & NM & Salado Formation & NM \\
\hline \multicolumn{8}{|c|}{$\begin{array}{l}\text { DTW = Depth to water (all measurements obtained from north } \\
\text { TOC = Top of casing elevation in feet above mean sea level } \\
\text { TSZ = Top of screen zone, uncased/open interval, or perforat } \\
\text { BSZ = Bottom of screen zone, uncased/open interval, or perfo } \\
\text { NM = Not measured } \\
\text { a Depth to water has not been corrected for true vertical depth. } \\
\text { b } \text { Elevation has been corrected for true vertical depth. } \\
\text { c Well USGS-1 has a dedicated submersible pump. }\end{array}$} \\
\hline
\end{tabular}

Pressure transducer data from on-site wells USGS-1, USGS-4, USGS-8, and LRL-7 are downloaded in January as part of the annual LM sampling event and again in late summer/fall as part of a regional monitoring event conducted by Sandia National Laboratories. Sandia did not download the transducer data from well DD-1 because access to this well is restricted. Hydrographs of hydraulic head data are shown in Figure 3 and Figure 4. The hydrographs are grouped according to each well's open interval and formation/unit monitored. A shift in data from wells USGS-4 and USGS-8 observed in April 2010 (Figure 3) occurred because the transducers were removed from the wells during well logging and were not returned to their original depth. The hydraulic head in well USGS-1 is affected by the on/off cycling of the dedicated pump that supplies water for ranchers. Hydraulic head data from wells USGS-1, USGS-4, and USGS-8 have been corrected for true vertical depth. Data obtained from well LRL-7 (Figure 4) indicate that water levels did not fully recover from the sampling conducted annually in January. Hydraulic head data from the transducer recently installed in well DD-1 will provide additional information associated with the Salado Formation.

\subsection{Groundwater Sampling and Results}

Groundwater samples were collected from wells USGS-1, USGS-4, USGS-8, and LRL-7 on January 26 and 27, 2010. Samples were not collected from the off-site locations. Monitoring wells USGS-4, USGS-8, and LRL-7 were sampled using dedicated low-flow submersible bladder pumps. The tubing inlets of the bladder pumps are located in the screened or open interval to allow water to be collected directly from the adjacent geologic formation. This limits the volume of purge water to the volume of water in the pump tubing, and the low flow rates minimize mixing with stagnant water in the well bore. The sample collected from well USGS-1 was collected as a grab sample because the pump was operating at the time of the sampling. Samples were analyzed for gamma-emitting radionuclides (using high-resolution gamma spectrometry), strontium-90, and tritium (using conventional and electrolytic enrichment methods). 


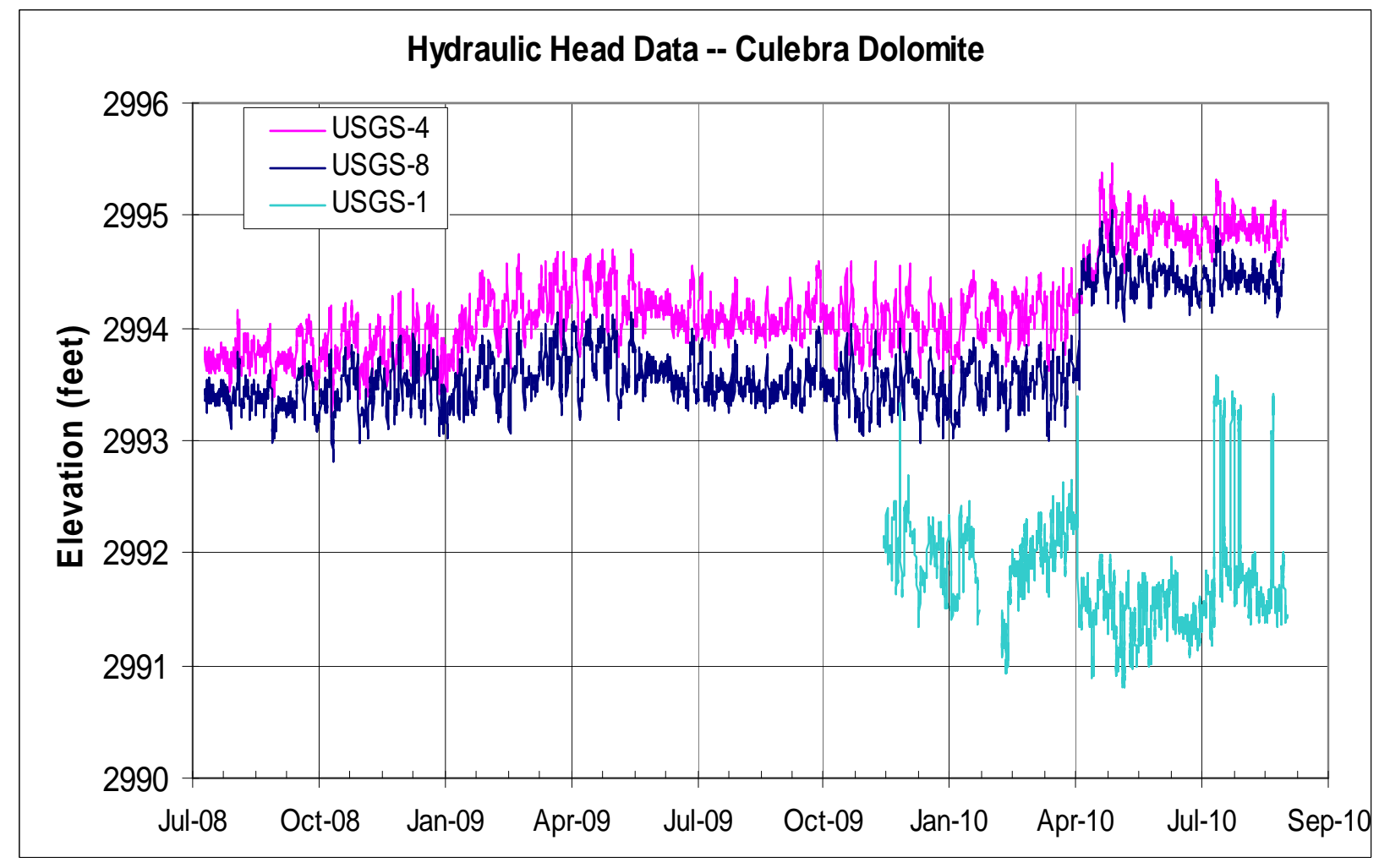

Figure 3. Hydrograph Showing Water Elevations in Wells USGS-1, USGS-4, and USGS-8

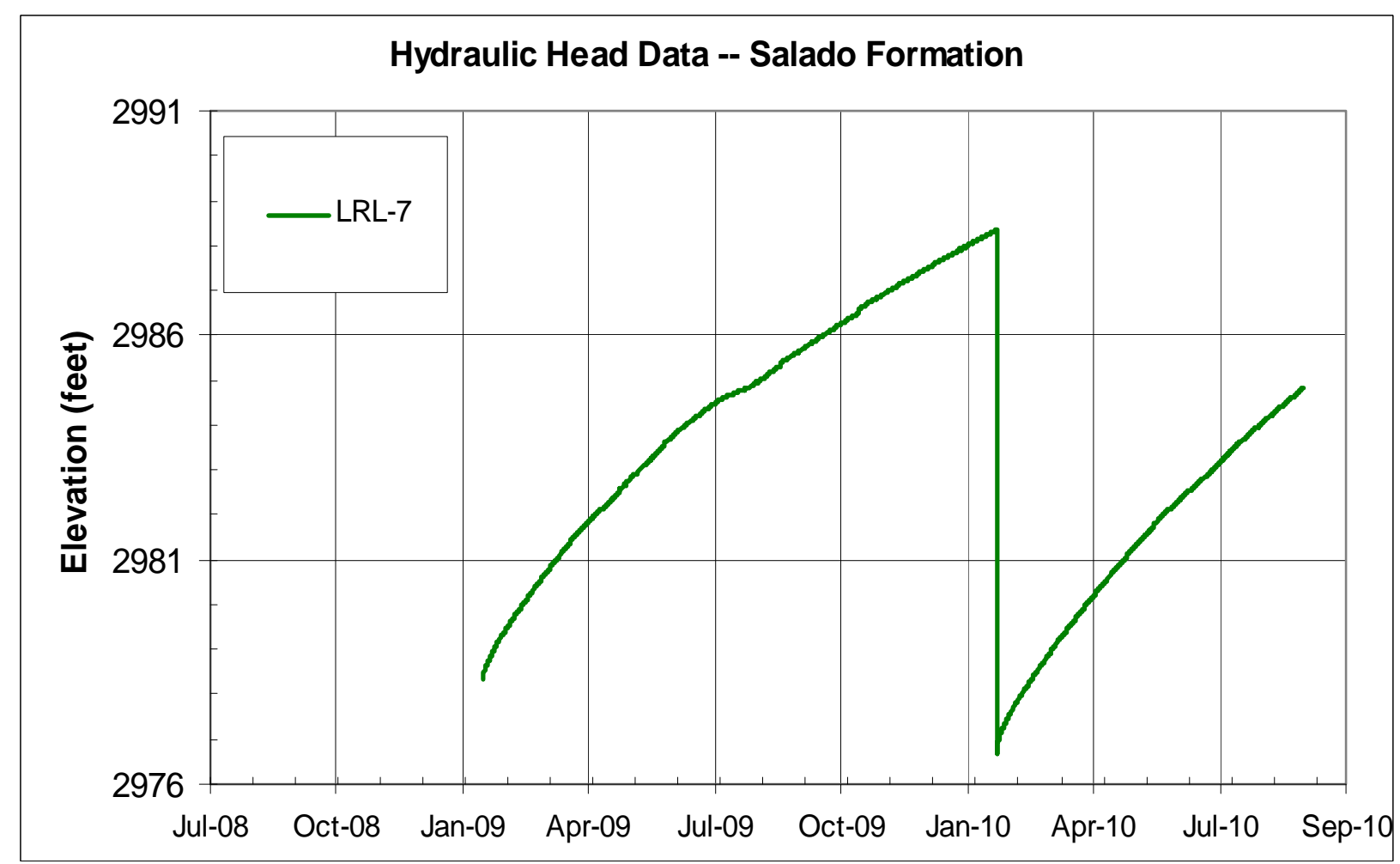

Figure 4. Hydrograph Showing Water Elevations in Well LRL-7 
Analytical results obtained from the 2010 monitoring event indicate that contaminant concentrations in on-site wells USGS-4, USGS-8, and LRL-7 were consistent with previous analytical results. Concentrations in well LRL-7 are the result of contamination from waste disposal during the site cleanup, and concentrations in wells USGS-4 and USGS-8 are the result of radionuclides injected during the tracer test in 1963. Cesium-137 concentrations in samples collected from wells USGS-8 and LRL-7 and tritium concentrations in samples collected from well LRL-7 during the 2008, 2009, and 2010 sampling events were higher than concentrations measured in 2007. The increased concentrations are due to changes in the sampling method that was implemented after the 2007 monitoring event, in which dedicated low-flow bladder pumps were installed. Table 4 lists the analytical results from the wells that were sampled during the January 2010 sampling event.

Table 4. Gnome Site Groundwater Sample Analytical Results

\begin{tabular}{||l|c|c|c|c|c|c||}
\hline $\begin{array}{c}\text { Sample } \\
\text { Location }\end{array}$ & $\begin{array}{c}\text { Collection } \\
\text { Date }\end{array}$ & $\begin{array}{c}\text { Tritium } \\
\text { (pCi/L) }\end{array}$ & $\begin{array}{c}\text { Enriched } \\
\text { Tritium } \\
\text { (pCi/L) }\end{array}$ & $\begin{array}{c}\text { Cesium-137 } \\
\text { (pCi/L) }\end{array}$ & $\begin{array}{c}\text { Strontium-90 } \\
\text { (pCi/L) }\end{array}$ & $\begin{array}{c}\text { Formation/Unit } \\
\text { Monitored }\end{array}$ \\
\hline USGS-1 & $01 / 26 / 2010$ & $<146$ & 7.6 & $<2.1$ & $<0.89$ & Culebra Dolomite \\
\hline USGS-1 (duplicate) & $01 / 26 / 2010$ & $<146$ & $<3.4$ & $<1.4$ & $<1.9$ & Culebra Dolomite \\
\hline USGS-4 & $01 / 26 / 2010$ & 13,200 & NA & $<1.4$ & 2,540 & Culebra Dolomite \\
\hline USGS-8 & $01 / 27 / 2010$ & 25,500 & NA & 181 & 3,320 & Culebra Dolomite \\
\hline LRL-7 & $01 / 26 / 2010$ & 4,350 & NA & 129 & $<33$ & Salado Formation \\
\hline
\end{tabular}

NA = not analyzed

$\mathrm{pCi} / \mathrm{L}=$ picocuries per liter

Estimated tritium concentration in a sample collected from well USGS-1 and analyzed by the electrolytic enriched method was 7.6 picocuries per liter (pCi/L). This concentration is below the worldwide tritium distribution in precipitation that resulted from aboveground nuclear tests during the 1950s and early 1960s (Brown 1995). For comparison, the EPA drinking water standard for tritium is $20,000 \mathrm{pCi} / \mathrm{L}$. The remaining analytical results obtained from well USGS-1 indicated no detections above laboratory method detection limits (Table 4).

Charts 1 through 7 in Appendix B show temporal plots of radionuclide concentrations (1972 through 2010) in samples collected at wells LRL-7, USGS-4, and USGS-8.

Concentration results are plotted on a semilogarithmic scale. All sample results, including nondetects, are plotted. As indicated in the figures, many results from sampling events before the late 1980s had no reported detection limit. For interpretation purposes, relatively high concentrations (i.e., concentrations significantly higher than detection limits associated with subsequent sampling) should be considered detections. 


\subsection{Conclusions}

The geophysical well logging was successful in obtaining borehole deviation data from wells USGS-1 and USGS-4, gamma ray logs from wells USGS-4 and USGS-8, and downhole video logs from wells USGS-4 and USGS-8. The borehole deviation data allow groundwater elevations to be calculated from true vertical depth corrected depth-to-water measurements. Groundwater elevations can be used to calculate hydraulic gradients and groundwater flow directions at the site. The gamma ray logs will be used for geologic information and to correlate with other wells in the area. Data obtained from the video logs suggest that the casings are in generally good condition for their age. The well-logging data support the use of wells USGS-1, USGS-4, and USGS-8 for long-term monitoring at the site.

Hydraulic head data obtained from well LRL-7 (Figure 4) indicate that water levels did not fully recover from the annual sampling conducted in January. Data from the transducer in well DD-1 will be downloaded as part of the annual sampling event in 2011 and will provide additional information on the Salado Formation. The concentrations of tritium, strontium-90, and cesium-137 in groundwater samples collected in January 2010 from on-site wells are consistent with concentrations from historical monitoring results.

\subsection{References}

Brown, R.M., 1995. Monthly Tritium in Precipitation at Ottawa, Canada, 1953-1995, Atomic Energy of Canada Limited, http://mysite.science.uottawa.ca/idclark/courses/Tritium\%20and\%20groundwater\%20age.doc, accessed February 2010.

DOE/NNSA (U.S. Department of Energy National Nuclear Security Administration), 2004. Surface Corrective Action Investigation Report for the Gnome-Coach Site, New Mexico, DOE/NV-926, May.

DOE/NNSA (U.S. Department of Energy National Nuclear Security Administration), 2005. Voluntary Remediation Program Completion Report Gnome-Coach Site, New Mexico, Rev. 1, DOE/NV-1077, December.

EPA (U.S. Environmental Protection Agency), 1972. Environmental Monitoring Report for the Nevada Test Site and Other Test Areas used for Underground Nuclear Detonations, NERC-LV-539-23, May.

Mercer, J.W., 1983. Geohydrology of the Proposed Waste Isolation Pilot Plant Site, Los Medaños Area, Southeastern New Mexico, U.S. Geological Survey Water-Resources Investigations Report 83-4016.

Rawson, D, C. Boudman, and N. Jaffe-Chazan, 1964. The Environment Created by a Nuclear Explosion in Salt, Lawrence Radiation Laboratory, University of California, Livermore, California, September.

REECO (Reynolds Electrical \& Engineering Company, Inc.), 1981. Gnome Site Decontamination and Decommissioning Project-Radiation Contamination Clearance Report, DOE/NV/004410-59, Las Vegas, Nevada, August. 
This page intentionally left blank 


\section{Appendix A}

\section{COLOG Well Logs and}

Eastman Deviation Data-USGS-8 
This page intentionally left blank 


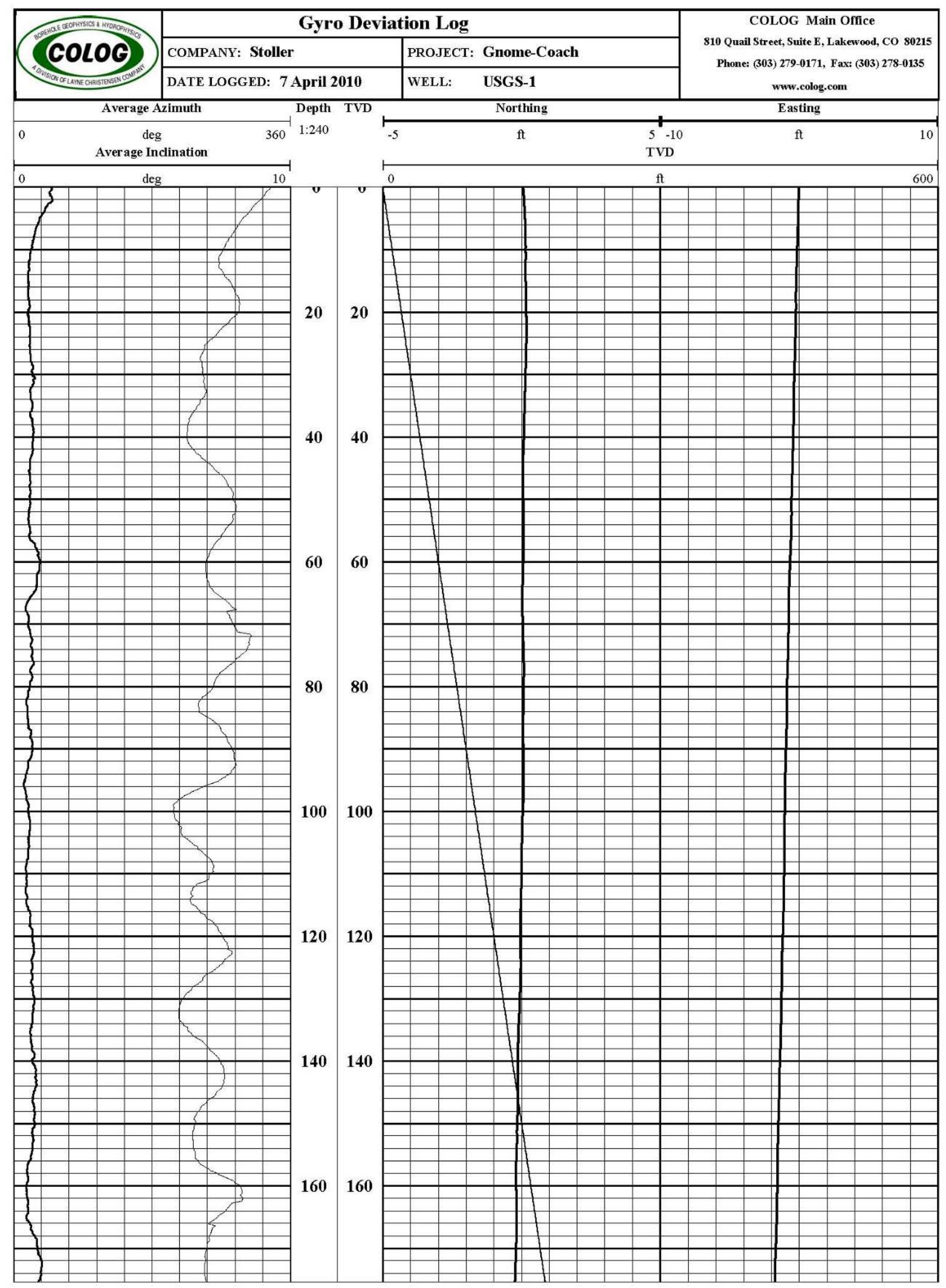




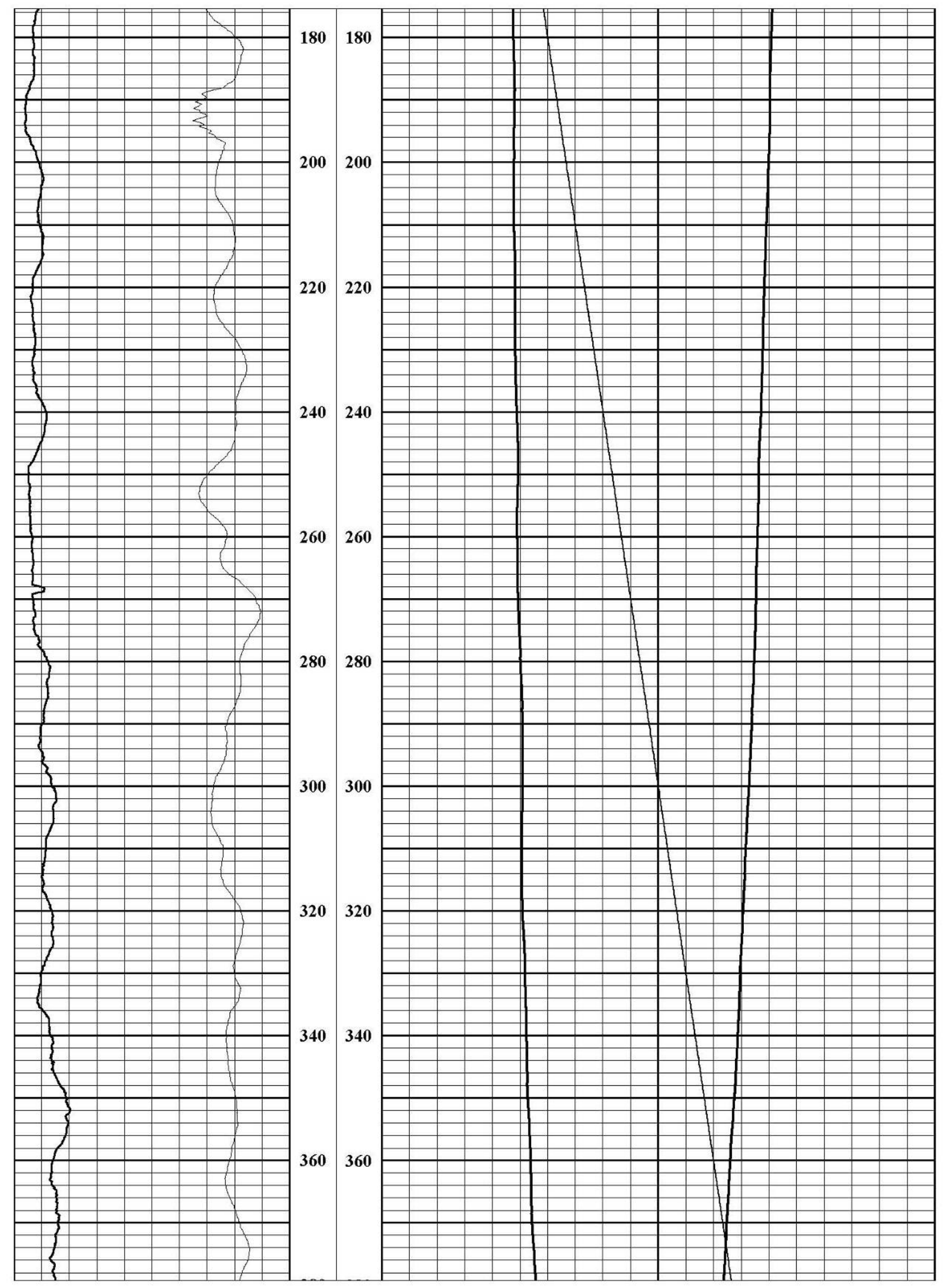




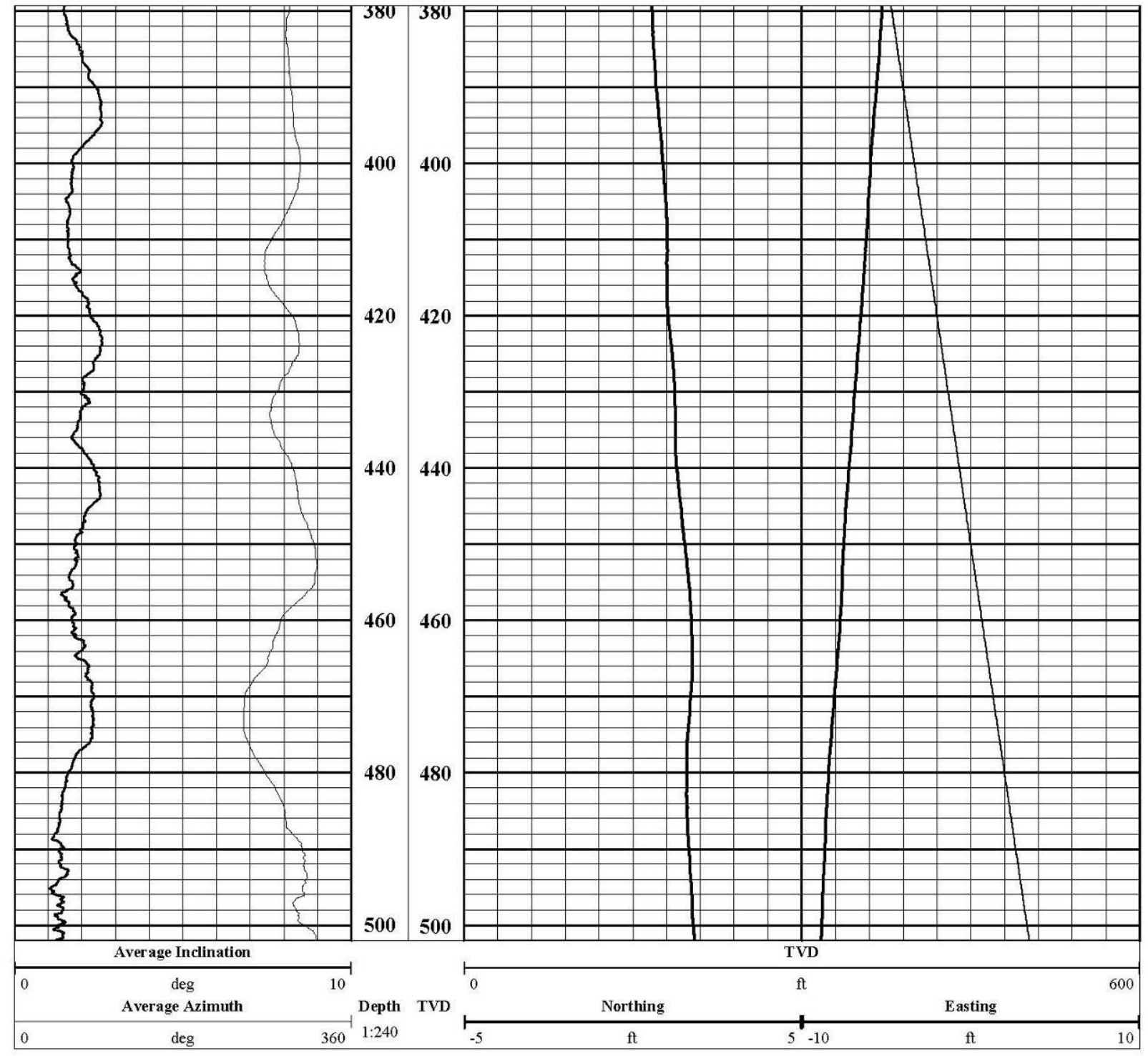


Sheet6

Deviation Survey for: $\quad$ S. M. Stoller Corporation

Well: USGS-1

Date: $\quad 4 / 7 / 2010$

$\begin{array}{llll}\text { Depth Ref.: GS } & \text { Total Depth: } 501.90 \mathrm{ft} & \text { Probe Type, S/N: }\end{array}$

Gyro

\begin{tabular}{|c|c|c|c|c|c|c|c|c|c|c|c|}
\hline $\begin{array}{l}\text { Depth } \\
\text { (feet) }\end{array}$ & \begin{tabular}{|c|} 
Inclination \\
(degrees)
\end{tabular} & $\begin{array}{c}\text { Bearing } \\
\text { (degrees) }\end{array}$ & $\begin{array}{l}\text { ClosureLength } \\
\text { (line ft.) }\end{array}$ & \begin{tabular}{|c} 
ClosureDist. \\
(horiz. ft.)
\end{tabular} & $\begin{array}{l}\text { ClosureDepth } \\
\text { (vertical ft.) }\end{array}$ & $\begin{array}{l}\text { Northing } \\
\text { (feet) }\end{array}$ & $\begin{array}{l}\text { Easting } \\
\text { (feet) }\end{array}$ & $\begin{array}{c}\begin{array}{c}\text { TrueDepth } \\
\text { (feet) }\end{array} \\
\end{array}$ & $\begin{array}{l}\begin{array}{l}\text { Dist.Sum } \\
\text { (feet) }\end{array}\end{array}$ & $\begin{array}{l}\text { NorthSum } \\
\text { (feet) }\end{array}$ & $\begin{array}{l}\begin{array}{l}\text { EastSum } \\
\text { (feet) }\end{array} \\
\text { feet }\end{array}$ \\
\hline 0.0 & 1.494 & 337.113 & 0.0 & 0.00 & 0.00 & 0.00 & 0.00 & 0.00 & 0.00 & 0.00 & 0.00 \\
\hline 3.0 & 1.159 & 319.852 & 0.3 & 0.01 & 0.30 & 0.00 & 0.00 & 2.73 & 0.06 & 0.05 & -0.04 \\
\hline 6.0 & 0.876 & 293.140 & 0.3 & 0.00 & 0.30 & 0.00 & 0.00 & 5.76 & 0.12 & 0.08 & -0.08 \\
\hline 9.0 & 0.553 & 274.508 & 0.3 & 0.00 & 0.30 & 0.00 & 0.00 & 8.78 & 0.15 & 0.09 & -0.12 \\
\hline 12.0 & 0.534 & 263.528 & 0.3 & 0.00 & 0.30 & 0.00 & 0.00 & 11.81 & 0.18 & 0.09 & -0.15 \\
\hline 15.0 & 0.524 & 288.762 & 0.3 & 0.00 & 0.30 & 0.00 & 0.00 & 14.84 & 0.20 & 0.09 & -0.18 \\
\hline 18.0 & 0.552 & 293.358 & 0.3 & 0.00 & 0.30 & 0.00 & 0.00 & 17.87 & 0.23 & 0.10 & -0.21 \\
\hline 21.0 & 0.634 & 289.181 & 0.3 & 0.00 & 0.30 & 0.00 & 0.00 & 20.90 & 0.26 & 0.11 & -0.23 \\
\hline 24.0 & 0.651 & 254.306 & 0.3 & 0.00 & 0.30 & 0.00 & 0.00 & 23.93 & 0.29 & 0.11 & -0.26 \\
\hline 27.0 & 0.603 & 241.392 & 0.3 & 0.00 & 0.30 & 0.00 & 0.00 & 26.96 & 0.31 & 0.10 & -0.29 \\
\hline 30.0 & 0.589 & 241.506 & 0.3 & 0.00 & 0.30 & 0.00 & 0.00 & 29.99 & 0.33 & 0.09 & -0.32 \\
\hline 33.0 & 0.587 & 247.920 & 0.3 & 0.00 & 0.30 & 0.00 & 0.00 & 32.72 & 0.36 & 0.08 & -0.35 \\
\hline 36.0 & 0.671 & 234.050 & 0.3 & 0.00 & 0.30 & 0.00 & 0.00 & 35.75 & 0.39 & 0.06 & -0.38 \\
\hline 39.0 & 0.781 & 225.462 & 0.3 & 0.00 & 0.30 & 0.00 & 0.00 & 38.78 & 0,41 & 0.04 & -0.41 \\
\hline 42.0 & 0.706 & 231.219 & 0.3 & 0.00 & 0.30 & 0.00 & 0.00 & 41.81 & 0.44 & 0.01 & -0.43 \\
\hline 45.0 & 0.476 & 258.092 & 0.3 & 0.00 & 0.30 & 0.00 & 0.00 & 44.84 & 0.46 & 0.00 & -0.46 \\
\hline 48.0 & 0.487 & 285.899 & 0.3 & 0.00 & 0.30 & 0.00 & 0.00 & 47.87 & 0.50 & 0.00 & -0.50 \\
\hline 51.0 & 0.608 & 282.986 & 0.3 & 0.00 & 0.30 & 0.00 & 0.00 & 50.90 & 0.53 & 0.01 & -0.53 \\
\hline 54.0 & 0.509 & 272.076 & 0.3 & 0.00 & 0.30 & 0.00 & 0.00 & 53.93 & 0.55 & 0.02 & -0.55 \\
\hline 57.0 & 0.708 & 262.431 & 0.3 & 0.00 & 0.30 & 0.00 & 0.00 & 56.96 & 0.59 & 0.02 & -0.59 \\
\hline 60.0 & 0.960 & 252.891 & $\overline{0.3}$ & 0.01 & 0.30 & 0.00 & 0.00 & 59.99 & 0.63 & 0.01 & -0.63 \\
\hline 63.0 & 0.837 & 250.791 & 0.3 & 0.00 & 0.30 & 0.00 & 0.00 & 62.71 & 0.67 & -0.01 & -0.67 \\
\hline 66.0 & 0.589 & 278.947 & 0.3 & 0.00 & 0.30 & 0.00 & 0.00 & 65.74 & 0.71 & -0.02 & -0.71 \\
\hline 69.0 & 0.565 & 290.230 & 0.3 & 0.00 & 0.30 & 0.00 & 0.00 & 68.77 & 0.73 & -0.01 & -0.73 \\
\hline 72.0 & 0.565 & 300.649 & 0.3 & 0.00 & 0.30 & 0.00 & 0.00 & 71.80 & 0.75 & 0.00 & -0.75 \\
\hline 75.0 & 0.720 & 299.787 & 0.3 & 0.00 & 0.30 & 0.00 & 0.00 & 74.83 & 0.78 & 0.02 & -0.78 \\
\hline 78.0 & 0.654 & 261.845 & $\overline{0.3}$ & 0.00 & 0.30 & 0.00 & 0.00 & 77.86 & 0.81 & 0.03 & -0.81 \\
\hline 81.0 & 0.526 & 258.926 & 0.3 & 0.00 & 0.30 & 0.00 & 0.00 & 80.89 & 0.85 & 0.03 & -0.84 \\
\hline 84.0 & 0.518 & 221.477 & 0.3 & 0.00 & 0.30 & 0.00 & 0.00 & 83.92 & 0.87 & 0.01 & -0.87 \\
\hline 87.0 & 0.482 & 264.214 & 0.3 & 0.00 & 0.30 & 0.00 & 0.00 & 86.95 & 0.89 & 0.01 & -0.89 \\
\hline 90.0 & 0.673 & 283.053 & 0.3 & 0.00 & 0.30 & 0.00 & 0.00 & 89.98 & 0.92 & 0.01 & -0.92 \\
\hline 93.0 & 0.506 & 286.276 & 0.3 & 0.00 & 0.30 & 0.00 & 0.00 & 92.70 & 0.95 & 0.02 & -0.95 \\
\hline 96.0 & 0.404 & 240.243 & 0.3 & 0.00 & 0.30 & 0.00 & 0.00 & 95.73 & 0.97 & 0.03 & -0.97 \\
\hline 99.0 & 0.564 & 211.830 & 0.3 & 0.00 & 0.30 & 0.00 & 0.00 & 98.76 & 0.99 & 0.01 & -0.99 \\
\hline 102.0 & 0.630 & 221.575 & 0.3 & 0.00 & 0.30 & 0.00 & 0.00 & 101.79 & 1.00 & -0.02 & -1.00 \\
\hline 105.0 & 0.586 & 214.123 & 0.3 & 0.00 & 0.30 & 0.00 & 0.00 & 104.82 & 1.02 & -0.04 & -1.02 \\
\hline 108.0 & 0.498 & 258.475 & 0.3 & 0.00 & 0.30 & 0.00 & 0.00 & 107.85 & 1.05 & -0.05 & -1.05 \\
\hline 111.0 & 0.462 & 240.148 & 0.3 & 0.00 & 0.30 & 0.00 & 0.00 & 110.88 & 1.07 & -0.05 & -1.07 \\
\hline 114.0 & 0.403 & 232.040 & 0.3 & 0.00 & 0.30 & 0.00 & 0.00 & 113.91 & 1.09 & -0.07 & -1.09 \\
\hline 117.0 & 0.583 & 253.838 & 0.3 & 0.00 & 0.30 & 0.00 & 0.00 & 116.94 & 1.11 & -0.08 & -1.11 \\
\hline 120.0 & 0.665 & 279.397 & 0.3 & 0.00 & 0.30 & 0.00 & 0.00 & 119.97 & 1.14 & -0.09 & -1.14 \\
\hline 123.0 & 0.708 & 269.537 & $\overline{0.3}$ & 0.00 & 0.30 & 0.00 & 0.00 & 122.70 & 1.18 & -0.08 & -1.17 \\
\hline 126.0 & 0.589 & 274.202 & 0.3 & 0.00 & 0.30 & 0.00 & 0.00 & 125.73 & 1.21 & -0.08 & -1.21 \\
\hline 129.0 & 0.703 & 219.377 & 0.3 & 0.00 & 0.30 & 0.00 & 0.00 & 128.76 & 1.24 & -0.10 & -1.24 \\
\hline 132.0 & 0.715 & 210.606 & 0.3 & 0.00 & 0.30 & 0.00 & 0.00 & 131.79 & 1.27 & -0.13 & -1.26 \\
\hline 135.0 & 0.622 & 225.495 & $\overline{0.3}$ & 0.00 & 0.30 & 0.00 & 0.00 & 134.82 & 1.29 & -0.16 & -1.28 \\
\hline 138.0 & 0.638 & 260.442 & 0.3 & 0.00 & 0.30 & 0.00 & 0.00 & 137.85 & 1.32 & -0.17 & -1.31 \\
\hline 141.0 & 0.885 & 277.793 & 0.3 & 0.00 & 0.30 & 0.00 & 0.00 & 140.88 & 1.36 & -0.17 & -1.35 \\
\hline 144.0 & 0.831 & 268.879 & 0.3 & 0.00 & 0.30 & 0.00 & 0.00 & 143.91 & 1.40 & -0.17 & -1.39 \\
\hline 147.0 & 0.694 & 249.545 & 0.3 & 0.00 & 0.30 & 0.00 & 0.00 & 146.93 & 1.44 & -0.17 & -1.43 \\
\hline 150.0 & 0.737 & 230.095 & 0.3 & 0.00 & 0.30 & 0.00 & 0.00 & 149.96 & 1.47 & -0.19 & -1.46 \\
\hline 153.0 & 0.721 & 232.603 & $\overline{0.0}$ & 0.00 & 0.00 & 0.00 & 0.00 & 152.99 & 1.50 & -0.22 & -1.49 \\
\hline 156.0 & 0.634 & 239.733 & 0.3 & 0.00 & 0.30 & 0.00 & 0.00 & 155.72 & 1.53 & -0.24 & -1.51 \\
\hline 159.0 & 0.643 & 290.353 & 0.3 & 0.00 & 0.30 & 0.00 & 0.00 & 158.75 & 1.56 & -0.24 & -1.54 \\
\hline 162.0 & 0.549 & 290.530 & 0.3 & 0.00 & 0.30 & 0.00 & 0.00 & 161.78 & 1.58 & -0.23 & -1.56 \\
\hline 165.0 & 0.446 & 274.805 & 0.3 & 0.00 & 0.30 & 0.00 & 0.00 & 164.81 & 1.60 & -0.23 & -1.58 \\
\hline 168.0 & 0.734 & 249.315 & 0.3 & 0.00 & 0.30 & 0.00 & 0.00 & 167.84 & 1.63 & -0.23 & -1.61 \\
\hline
\end{tabular}

Page 1 
Sheet6

\begin{tabular}{|c|c|c|c|c|c|c|c|c|c|c|c|}
\hline \multicolumn{3}{|c|}{ Deviation Survey for: } & \multicolumn{3}{|c|}{ S. M. Stoller Corporation } & Field: & \multicolumn{2}{|c|}{ Gnome-Coach } & \multirow{2}{*}{\multicolumn{2}{|c|}{$\begin{array}{l}\text { Date: } \quad 4 / 7 / 2010 \\
\text { Probe Type, S/N: }\end{array}$}} & \multirow[b]{2}{*}{ Gyro } \\
\hline Well: & USGS-1 & & Depth Ref.: & GS & Total Depth: & 501.90 & & & & & \\
\hline $\begin{array}{l}\text { Depth } \\
\text { (feet) }\end{array}$ & $\begin{array}{c}\begin{array}{c}\text { Inclination } \\
\text { (degrees) }\end{array} \\
\end{array}$ & $\begin{array}{c}\text { Bearing } \\
\text { (degrees) }\end{array}$ & \begin{tabular}{|c}
$\begin{array}{c}\text { ClosureLength } \\
\text { (line ft.) }\end{array}$ \\
\end{tabular} & $\begin{array}{l}\text { ClosureDist. } \\
\text { (horiz. ft.) }\end{array}$ & $\begin{array}{c}\text { ClosureDepth } \\
\text { (vertical ft.) }\end{array}$ & $\begin{array}{c}\begin{array}{c}\text { Northing } \\
\text { (feet) }\end{array} \\
\end{array}$ & $\begin{array}{l}\text { Easting } \\
\text { (feet) }\end{array}$ & $\begin{array}{c}\text { TrueDepth } \\
\text { (feet) }\end{array}$ & \begin{tabular}{|c|}
$\begin{array}{c}\text { Dist.Sum } \\
\text { (feet) }\end{array}$ \\
\end{tabular} & $\begin{array}{l}\text { NorthSum } \\
\text { (feet) }\end{array}$ & $\begin{array}{c}\begin{array}{c}\text { EastSum } \\
\text { (feet) }\end{array} \\
\end{array}$ \\
\hline 171.0 & \begin{tabular}{|l|}
0.960 \\
\end{tabular} & 240.736 & $\begin{array}{r}0.3 \\
\end{array}$ & 0.01 & 0.30 & 0.00 & 0.00 & 170.87 & 1.67 & -0.24 & -1.65 \\
\hline 174.0 & 1.054 & 245.486 & 0.3 & 0.01 & 0.30 & 0.00 & -0.01 & 173.90 & 1.72 & -0.26 & -1.70 \\
\hline 177.0 & 0.681 & 261.002 & 0.3 & 0.00 & 0.30 & 0.00 & 0.00 & 176.93 & 1.77 & -0.28 & -1.75 \\
\hline 180.0 & 0.718 & 294.819 & 0.3 & 0.00 & 0.30 & 0.00 & 0.00 & 179.96 & 1.80 & -0.28 & -1.78 \\
\hline 183.0 & 0.720 & 303.264 & 0.3 & 0.00 & 0.30 & 0.00 & 0.00 & 182.99 & 1.83 & -0.26 & -1.82 \\
\hline 186.0 & 0.719 & 286.312 & 0.3 & 0.00 & 0.30 & 0.00 & 0.00 & 185.71 & 1.86 & -0.25 & -1.85 \\
\hline 189.0 & 0.422 & 234.582 & 0.3 & 0.00 & 0.30 & 0.00 & 0.00 & 188.74 & 1.89 & -0.24 & -1.88 \\
\hline 192.0 & 0.388 & 218.290 & 0.3 & 0.00 & 0.30 & 0.00 & 0.00 & 191.77 & 1.91 & -0.25 & -1.89 \\
\hline 195.0 & 0.335 & 227.845 & 0.3 & 0.00 & 0.30 & 0.00 & 0.00 & 194.80 & 1.92 & -0.26 & -1.91 \\
\hline 198.0 & 0.820 & 277.907 & 0.3 & 0.00 & 0.30 & 0.00 & 0.00 & 197.83 & 1.95 & -0.26 & -1.93 \\
\hline 201.0 & 0.989 & 265.455 & 0.3 & 0.01 & 0.30 & 0.00 & \begin{tabular}{|c|}
-0.01 \\
\end{tabular} & 200.86 & 2.00 & -0.26 & -1.98 \\
\hline 204.0 & 1.003 & 260.044 & 0.3 & 0.01 & 0.30 & 0.00 & -0.01 & 203.89 & 2.05 & -0.26 & -2.03 \\
\hline 207.0 & 0.919 & 271.036 & 0.3 & 0.00 & 0.30 & 0.00 & 0.00 & 206.92 & 2.10 & -0.27 & -2.08 \\
\hline 210.0 & 0.867 & 284.867 & 0.3 & 0.00 & 0.30 & 0.00 & 0.00 & 209.95 & 2.14 & -0.26 & -2.13 \\
\hline 213.0 & 1.045 & 294.180 & 0.3 & 0.01 & 0.30 & 0.00 & 0.00 & 212.98 & 2.19 & -0.24 & -2.18 \\
\hline 216.0 & 1.000 & 277.429 & 0.3 & 0.01 & 0.30 & 0.00 & -0.01 & 215.71 & 2.24 & -0.23 & -2.22 \\
\hline 219.0 & 0.615 & 261.220 & 0.3 & 0.00 & 0.30 & 0.00 & 0.00 & 218.73 & 2.28 & -0.23 & -2.27 \\
\hline 222.0 & 0.623 & 261.089 & 0.3 & 0.00 & 0.30 & 0.00 & 0.00 & 221.76 & 2.31 & -0.23 & -2.30 \\
\hline 225.0 & \begin{tabular}{|c|}
0.673 \\
\end{tabular} & 266.404 & 0.3 & 0.00 & 0.30 & 0.00 & 0.00 & 224.79 & 2.35 & -0.24 & -2.34 \\
\hline 228.0 & \begin{tabular}{|l|}
0.793 \\
\end{tabular} & 287.194 & 0.3 & 0.00 & 0.30 & 0.00 & 0.00 & 227.82 & 2.38 & -0.23 & -2.37 \\
\hline 231.0 & 0.709 & 302.369 & 0.3 & 0.00 & 0.30 & 0.00 & 0.00 & 230.85 & 2.42 & -0.22 & -2.41 \\
\hline 234.0 & 0.720 & 301.949 & 0.3 & 0.00 & 0.30 & 0.00 & 0.00 & 233.88 & 2.45 & -0.20 & -2.44 \\
\hline 237.0 & 0.806 & 289.827 & 0.3 & 0.00 & 0.30 & 0.00 & 0.00 & 236.91 & 2.48 & -0.18 & -2.48 \\
\hline 240.0 & 1.118 & 286.723 & 0.3 & 0.01 & 0.30 & 0.00 & -0.01 & 239.94 & 2.53 & -0.16 & -2.52 \\
\hline 243.0 & 1.077 & 293.581 & 0.3 & 0.01 & 0.30 & 0.00 & -0.01 & 242.97 & 2.59 & -0.14 & -2.58 \\
\hline 246.0 & \begin{tabular}{|c|}
0.913 \\
\end{tabular} & 285.449 & 0.3 & 0.00 & 0.30 & 0.00 & 0.00 & 245.70 & 2.63 & -0.13 & -2.63 \\
\hline 249.0 & 0.540 & 259.159 & 0.3 & 0.00 & 0.30 & 0.00 & 0.00 & 248.73 & 2.67 & -0.12 & -2.66 \\
\hline 252.0 & \begin{tabular}{|c|}
0.593 \\
\end{tabular} & 243.700 & 0.3 & 0.00 & 0.30 & 0.00 & 0.00 & 251.76 & 2.69 & -0.13 & -2.69 \\
\hline 255.0 & 0.583 & 248.396 & 0.3 & 0.00 & 0.30 & 0.00 & 0.00 & 254.79 & 2.72 & -0.15 & -2.72 \\
\hline 258.0 & 0.568 & 279.427 & 0.3 & 0.00 & 0.30 & 0.00 & 0.00 & 257.82 & 2.75 & -0.15 & -2.75 \\
\hline 261.0 & 0.590 & 270.294 & 0.3 & 0.00 & 0.30 & 0.00 & 0.00 & 260.84 & 2.78 & -0.15 & -2.78 \\
\hline 264.0 & $\mid 0.664$ & 264.518 & 0.3 & 0.00 & 0.30 & 0.00 & 0.00 & 263.87 & 2.82 & -0.15 & -2.81 \\
\hline 267.0 & 0.641 & 288.254 & 0.3 & 0.00 & 0.30 & 0.00 & 0.00 & 266.90 & 2.85 & -0.14 & -2.85 \\
\hline 270.0 & 0.712 & 316.378 & 0.3 & 0.00 & 0.30 & 0.00 & 0.00 & 269.93 & 2.88 & -0.12 & -2.88 \\
\hline 273.0 & 0.712 & 313.986 & 0.3 & 0.00 & 0.30 & 0.00 & 0.00 & 272.96 & 2.91 & -0.09 & -2.90 \\
\hline 276.0 & 0.786 & 306.743 & 0.3 & 0.00 & 0.30 & 0.00 & 0.00 & 275.69 & 2.93 & -0.07 & -2.93 \\
\hline 279.0 & 1.091 & 296.237 & 0.3 & 0.01 & 0.30 & 0.00 & -0.01 & 278.72 & 2.97 & -0.04 & -2.97 \\
\hline 282.0 & 1.304 & 293.085 & 0.3 & 0.01 & 0.30 & 0.00 & -0.01 & 281.75 & \begin{tabular}{l|}
3.03 \\
\end{tabular} & -0.02 & -3.03 \\
\hline 285.0 & 1.276 & 292.557 & 0.3 & 0.01 & 0.30 & 0.00 & -0.01 & 284.78 & 3.09 & 0.01 & -3.09 \\
\hline 288.0 & 1.042 & 285.255 & 0.3 & 0.01 & 0.30 & 0.00 & -0.01 & 287.81 & 3.15 & 0.04 & -3.15 \\
\hline 291.0 & 0.990 & 276.959 & 0.3 & 0.01 & 0.30 & 0.00 & -0.01 & 290.84 & 3.20 & 0.04 & -3.20 \\
\hline 294.0 & 0.931 & 271.279 & 0.3 & 0.00 & 0.30 & 0.00 & 0.00 & 293.86 & 3.25 & 0.05 & -3.25 \\
\hline 297.0 & 1.381 & 269.195 & 0.3 & 0.01 & 0.30 & 0.00 & -0.01 & 296.89 & 3.30 & 0.06 & -3.30 \\
\hline 300.0 & 1.491 & 260.985 & 0.3 & 0.01 & 0.30 & 0.00 & -0.01 & 299.92 & \begin{tabular}{|l|}
3.37 \\
\end{tabular} & 0.05 & \begin{tabular}{|c|}
-3.37 \\
\end{tabular} \\
\hline 303.0 & 1.440 & 256.358 & 0.3 & 0.01 & 0.30 & 0.00 & $\mid-0.01$ & 302.95 & 3.45 & 0.03 & -3.45 \\
\hline 306.0 & 1.410 & 256.214 & 0.0 & 0.00 & 0.00 & 0.00 & 0.00 & 305.98 & 3.52 & 0.02 & -3.52 \\
\hline 309.0 & 1.159 & 270.196 & 0.3 & 0.01 & 0.30 & 0.00 & -0.01 & 308.71 & 3.58 & 0.01 & -3.58 \\
\hline 312.0 & 0.932 & 271.800 & 0.3 & 0.00 & 0.30 & 0.00 & 0.00 & 311.74 & 3.64 & 0.01 & -3.64 \\
\hline 315.0 & 1.050 & 268.919 & 0.3 & 0.01 & 0.30 & 0.00 & -0.01 & 314.77 & 3.69 & 0.02 & -3.69 \\
\hline 318.0 & 1.202 & 288.449 & 0.3 & 0.01 & 0.30 & 0.00 & \begin{tabular}{|c|}
-0.01 \\
\end{tabular} & 317.79 & 3.75 & 0.02 & -3.75 \\
\hline 321.0 & 1.382 & 300.981 & 0.3 & 0.01 & 0.30 & 0.00 & -0.01 & 320.82 & 3.81 & 0.05 & -3.81 \\
\hline 324.0 & 1.391 & 298.643 & 0.3 & 0.01 & 0.30 & 0.00 & -0.01 & 323.85 & 3.88 & 0.08 & -3.87 \\
\hline 327.0 & 1.240 & 288.955 & 0.3 & 0.01 & 0.30 & 0.00 & $\mid-0.01$ & 326.88 & 3.94 & 0.11 & -3.94 \\
\hline 330.0 & 0.990 & 284.166 & 0.3 & 0.01 & 0.30 & 0.00 & \begin{tabular}{|c|}
-0.01 \\
\end{tabular} & 329.91 & 4.00 & 0.13 & -4.00 \\
\hline 333.0 & 0.836 & 301.648 & 0.3 & 0.00 & 0.30 & 0.00 & 0.00 & 332.94 & 4.05 & 0.15 & -4.04 \\
\hline 336.0 & 1.137 & 279.359 & 0.3 & 0.01 & 0.30 & 0.00 & -0.01 & 335.97 & 4.09 & 0.17 & -4.08 \\
\hline 339.0 & 1.279 & 278.419 & 0.3 & 0.01 & 0.30 & 0.00 & \begin{tabular}{|c|}
-0.01 \\
\end{tabular} & 338.70 & 4.15 & 0.18 & -4.14 \\
\hline
\end{tabular}

Page 2 


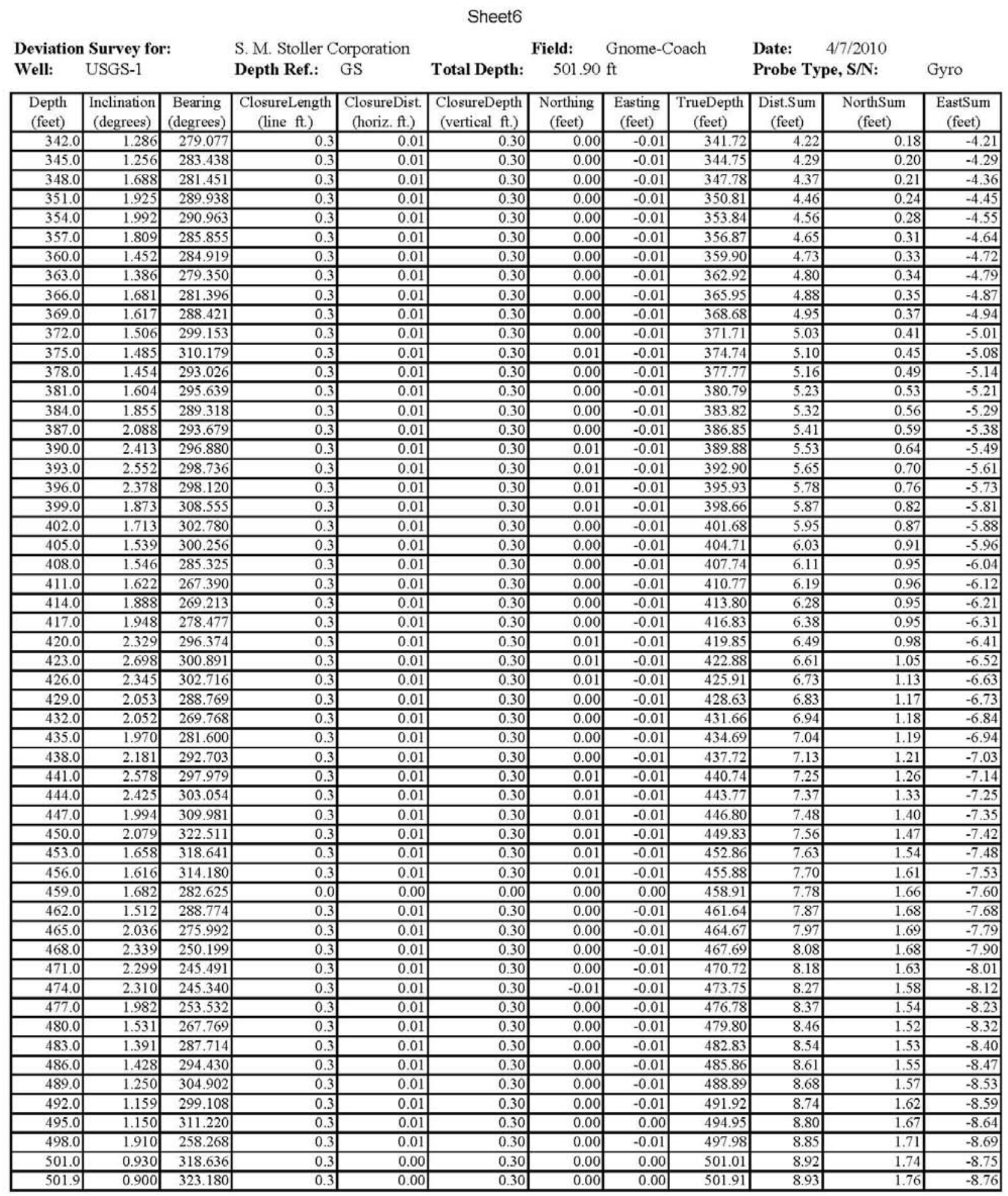

Page 3

2010 Groundwater Monitoring and Inspection Report Gnome-Coach, New Mexico Doc. No. S07114

Page A-6
U.S. Department of Energy

February 2011 
Sheet6

\begin{tabular}{|c|c|c|c|c|c|c|c|c|c|c|c|}
\hline \multirow{2}{*}{\multicolumn{3}{|c|}{$\begin{array}{l}\text { Deviation Survey for: } \\
\text { Well: USGS-1 }\end{array}$}} & \multicolumn{3}{|c|}{ S. M. Stoller Corporation } & Field: & \multicolumn{2}{|c|}{ Gnome-Coach } & \multirow{2}{*}{\multicolumn{2}{|c|}{$\begin{array}{l}\text { Date: } \quad 4 / 7 / 2010 \\
\text { Probe Type, } \mathbf{S} / \mathbf{N} \text { : }\end{array}$}} & \multirow[b]{2}{*}{ Gyro } \\
\hline & & & Depth Ref.: & GS & Total Depth: & 501.9 & $\mathrm{ft}$ & & & & \\
\hline \multirow[t]{4}{*}{$\begin{array}{l}\text { Depth } \\
\text { (feet) }\end{array}$} & \multirow[t]{4}{*}{\begin{tabular}{|c|}
$\begin{array}{c}\text { Inclination } \\
\text { (degrees) }\end{array}$ \\
\end{tabular}} & \multirow[t]{4}{*}{$\begin{array}{c}\text { Bearing } \\
\text { (degrees) }\end{array}$} & \multirow[t]{4}{*}{ 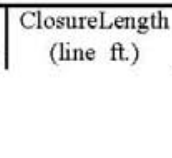 } & \multirow[t]{4}{*}{$\begin{array}{c}\text { ClosureDist. } \\
\text { (horiz. ft.) }\end{array}$} & \multirow[t]{4}{*}{\begin{tabular}{|c|}
$\begin{array}{c}\text { ClosureDepth } \\
\text { (vertical ft.) }\end{array}$ \\
\end{tabular}} & \multirow[t]{4}{*}{$\begin{array}{c}\text { Northing } \\
\text { (feet) }\end{array}$} & \multirow[t]{4}{*}{$\begin{array}{c}\text { Easting } \\
\text { (feet) }\end{array}$} & $\begin{array}{c}\text { TrueDepth } \\
\text { (feet) }\end{array}$ & $\begin{array}{c}\text { Dist.Sum } \\
\text { (feet) }\end{array}$ & $\begin{array}{c}\begin{array}{c}\text { NorthSum } \\
\text { (feet) }\end{array} \\
\end{array}$ & $\begin{array}{l}\text { EastSum } \\
\text { (feet) }\end{array}$ \\
\hline & & & & & & & & \multicolumn{4}{|l|}{ Totals: } \\
\hline & & & & & & & & $\begin{array}{l}\text { True Depth } \\
\end{array}$ & DistSum & NorthSum & EastSum \\
\hline & & & & & & & & 501.91 & 8.93 & 1.76 & -8.76 \\
\hline
\end{tabular}

\begin{tabular}{|c|}
\hline Definitions \\
\hline Bearing = Azimuth Degrees from Magnetic North (Raw Data) \\
\hline ClosureDistance $=$ Horizontal Feet Between Each Station \\
\hline ClosureDepth $=$ Vertical Feet Between Each Interval \\
\hline $\begin{aligned} \text { Northing } & =\text { North/South Component of Horizontal Distance Between Each Station }(\text { Negative }=\text { South }) \\
& \text { (Closure Dist.) } x \cos (\text { Bearing })\end{aligned}$ \\
\hline $\begin{aligned} \text { Easting = } & \text { East/West Component of Horizontal Distance Between Each Station (Negative }=\text { West) } \\
& \text { (Closure Dist.) } x \sin (\text { Bearing })\end{aligned}$ \\
\hline TrueDepth $=$ Vertical Depth from the Surface to This Station \\
\hline DistanceSum = Horizontal Distance from Wellhead to this Station \\
\hline $\begin{aligned} \text { NorthSum } & =\text { North/South Component of Horizontal Distance from the Wellhead to This Station (Negative }=\text { South) } \\
& \text { Running Sum of Northing }\end{aligned}$ \\
\hline $\begin{aligned} \text { EastSum } & =\text { East/West Component of Horizontal Distance from the Wellhead to This Station (Negative }=\text { West) } \\
& \text { Running Sum of Easting }\end{aligned}$ \\
\hline
\end{tabular}

Page 4 
Deviation Survey for:

Well: USGS-1
S. M. Stoller Corporation Depth Ref.: GS
Field: Gnome-Couch Total Dept] $\quad 501.90 \mathrm{ft}$
Date: $\quad 4 / 7 / 2010$ Probe Type, S/N: Gyro
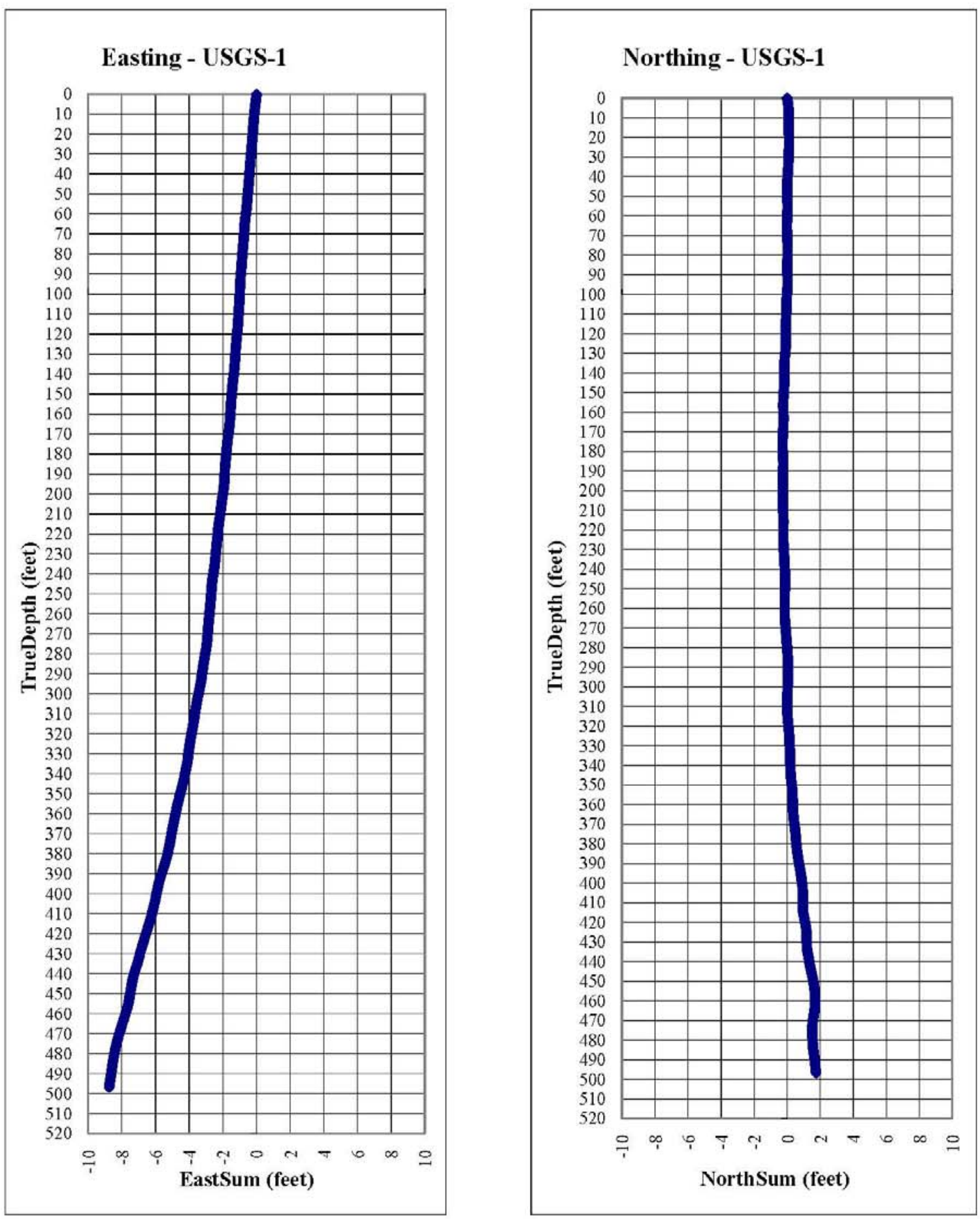

Orientations are with respect to Magnetic North

2010 Groundwater Monitoring and Inspection Report Gnome-Coach, New Mexico 
COLOG division of Layne Christensen Company

Page 1 of 1

Deviation Survey for:

S. M. Stoller Corporation

Field: $\quad$ Gnome-Coach

Depth Ref.: GS

Total Deptl $\quad 501.90 \mathrm{ft}$

Date: $\quad 4 / 7 / 2010$

Probe Type, S/N: Gyro

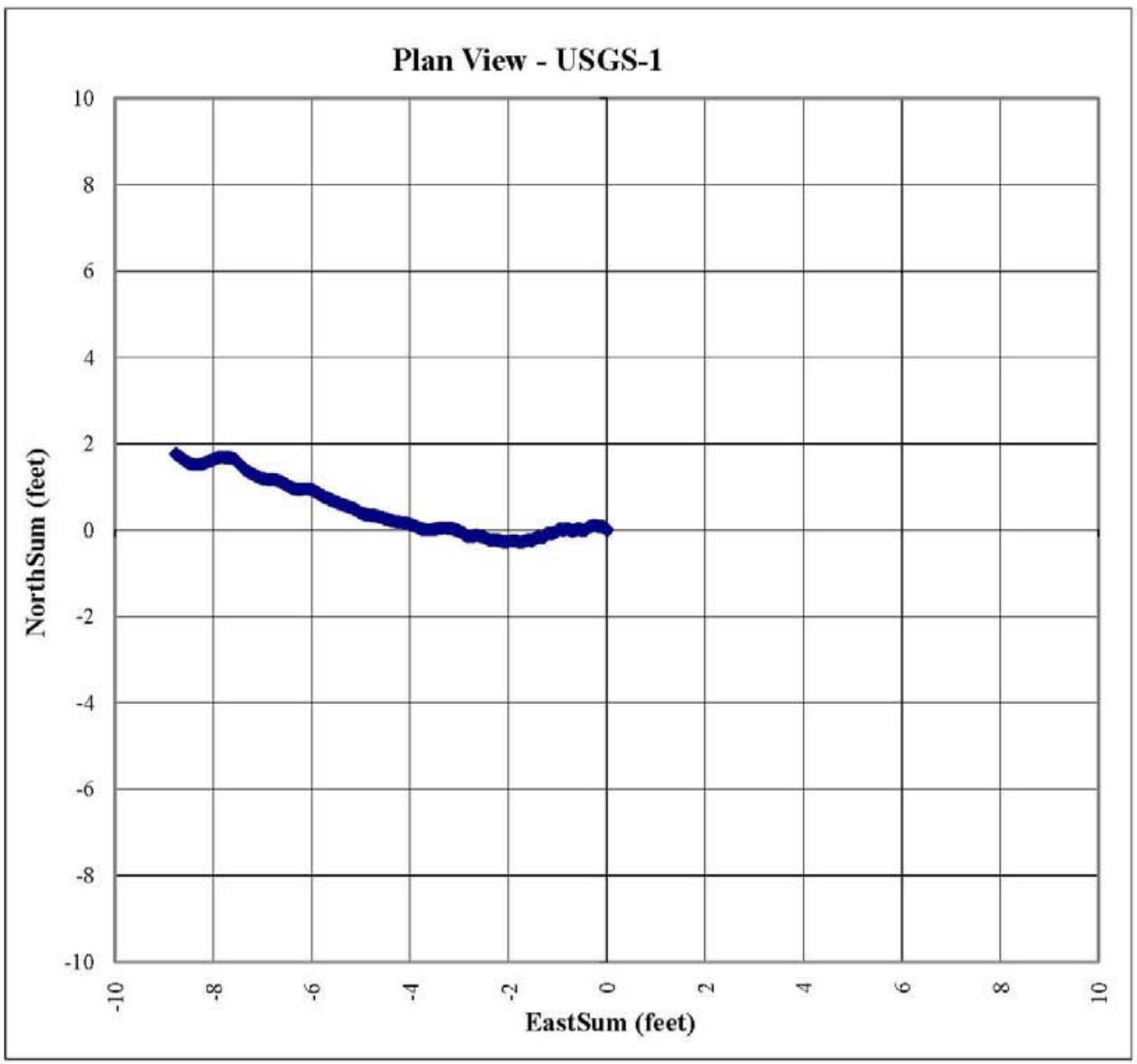

Orientations are with respect to Magnetic North 


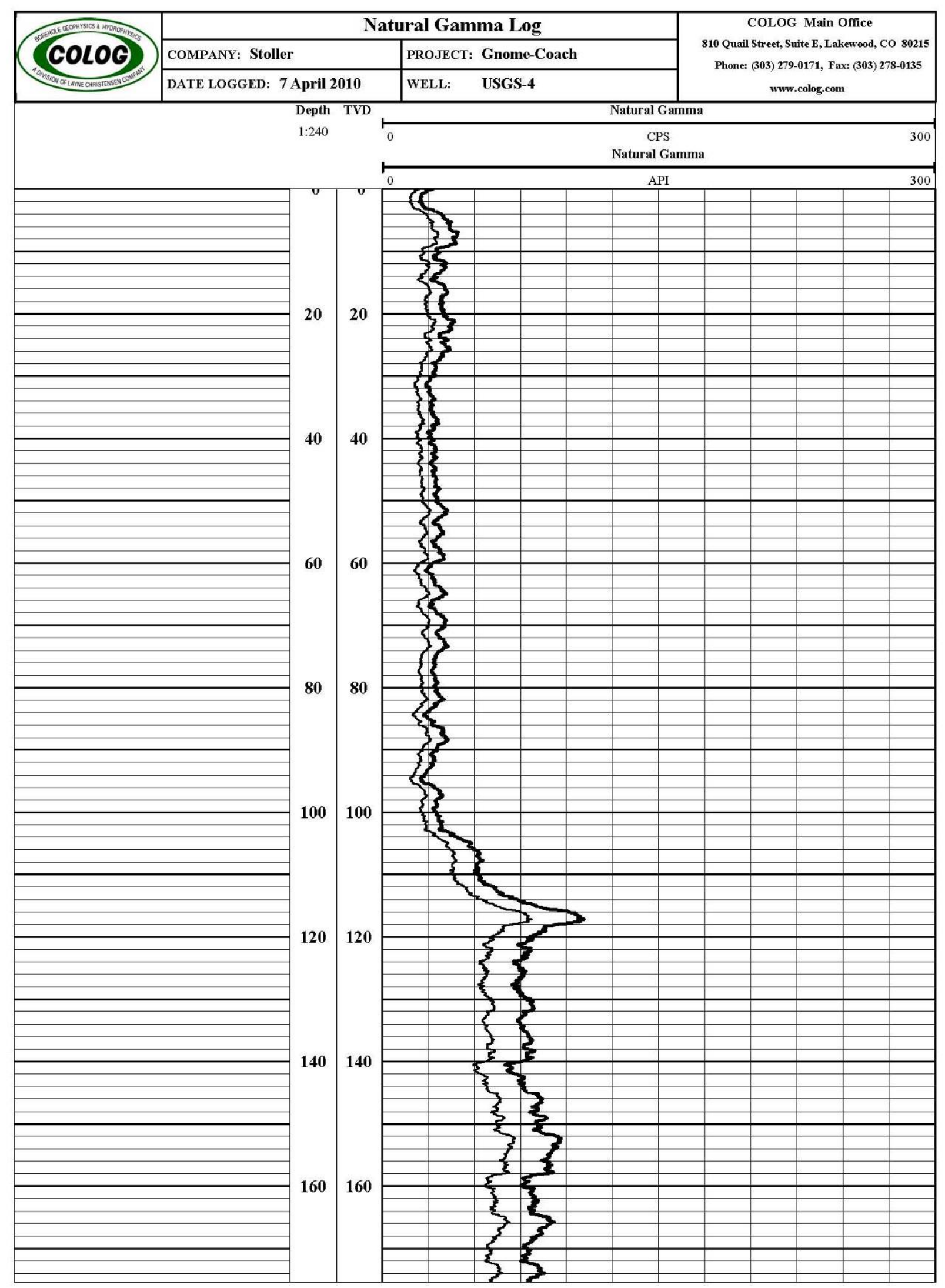

2010 Groundwater Monitoring and Inspection Report Gnome-Coach, New Mexico 


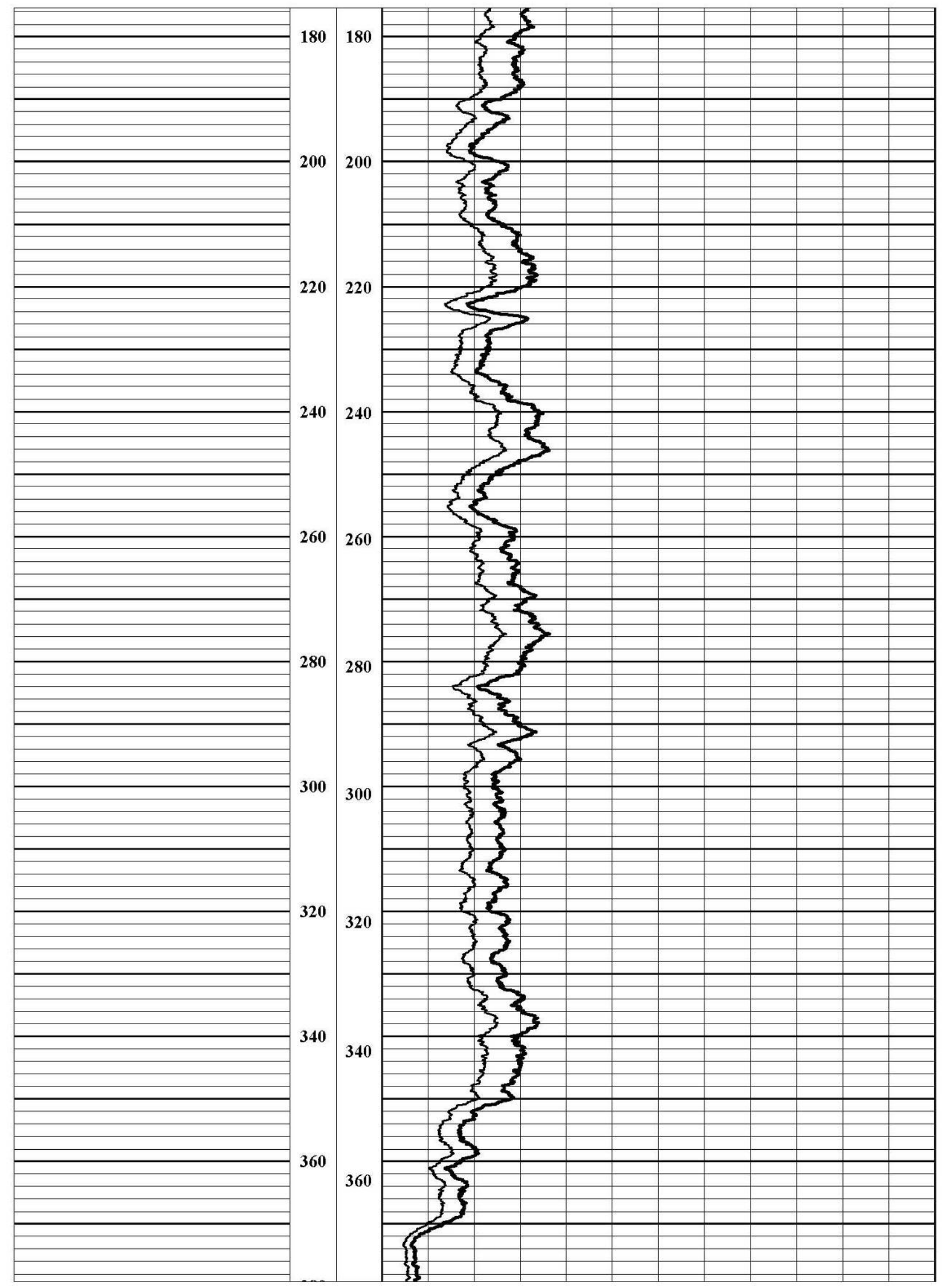




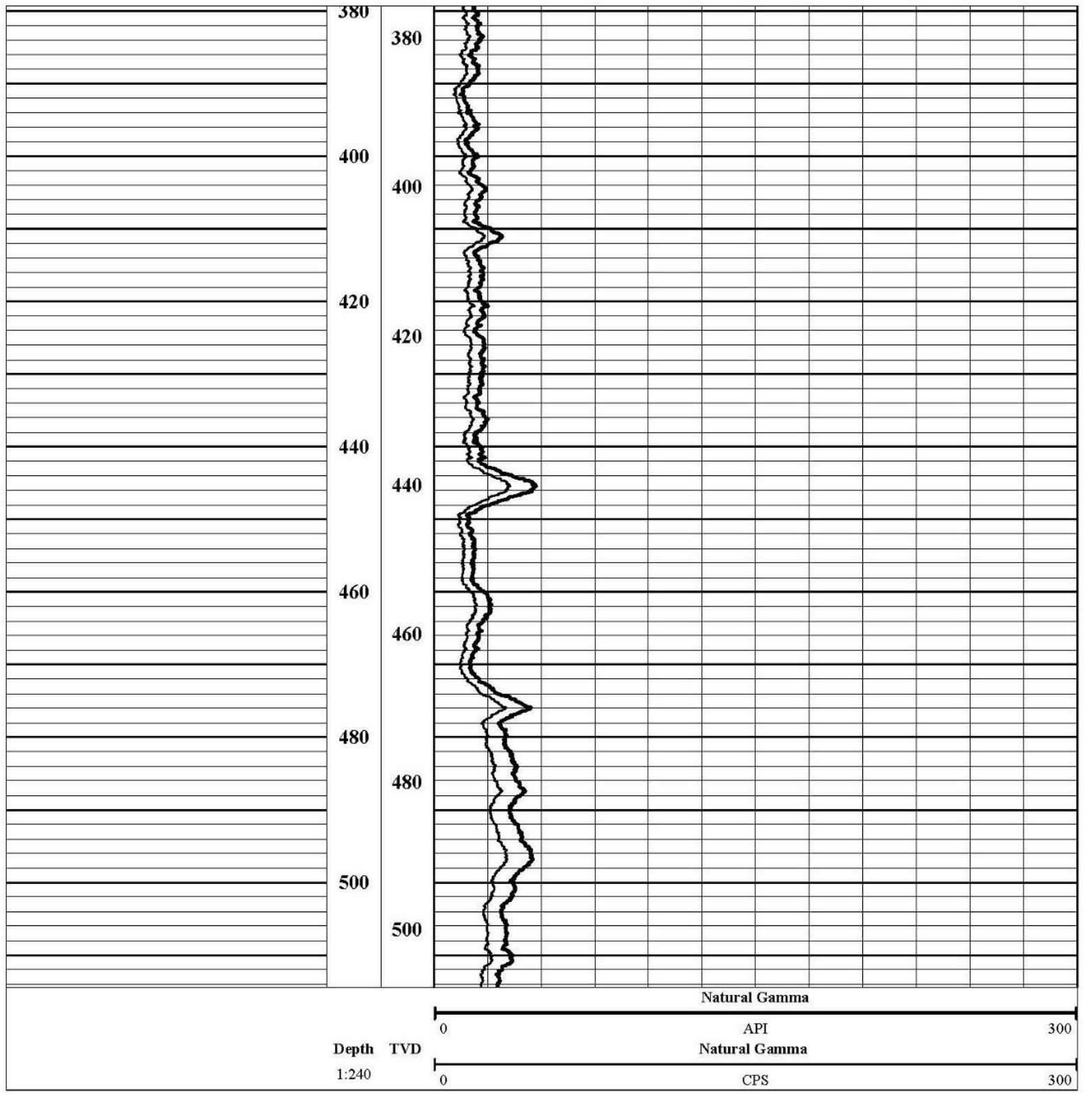




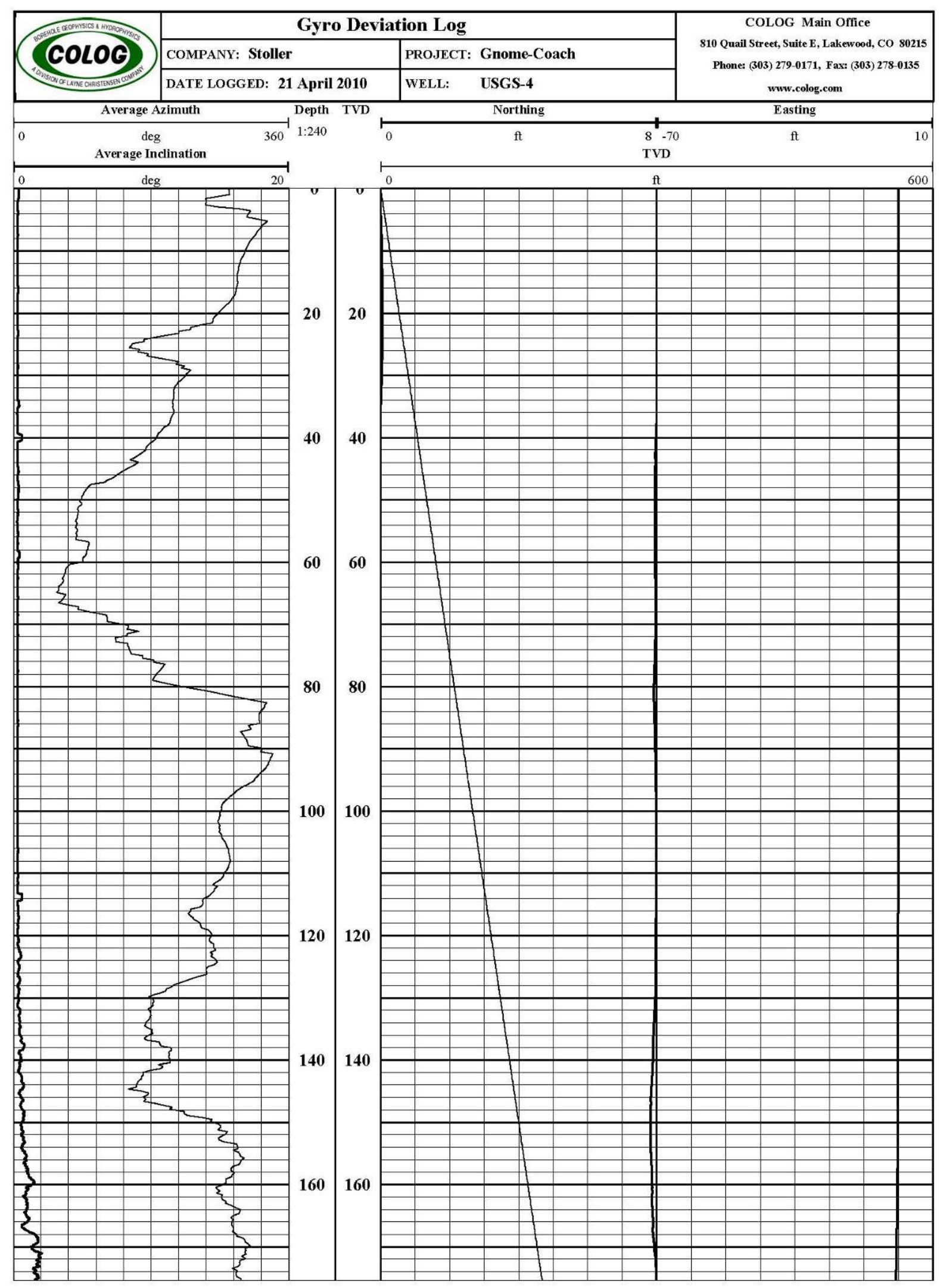




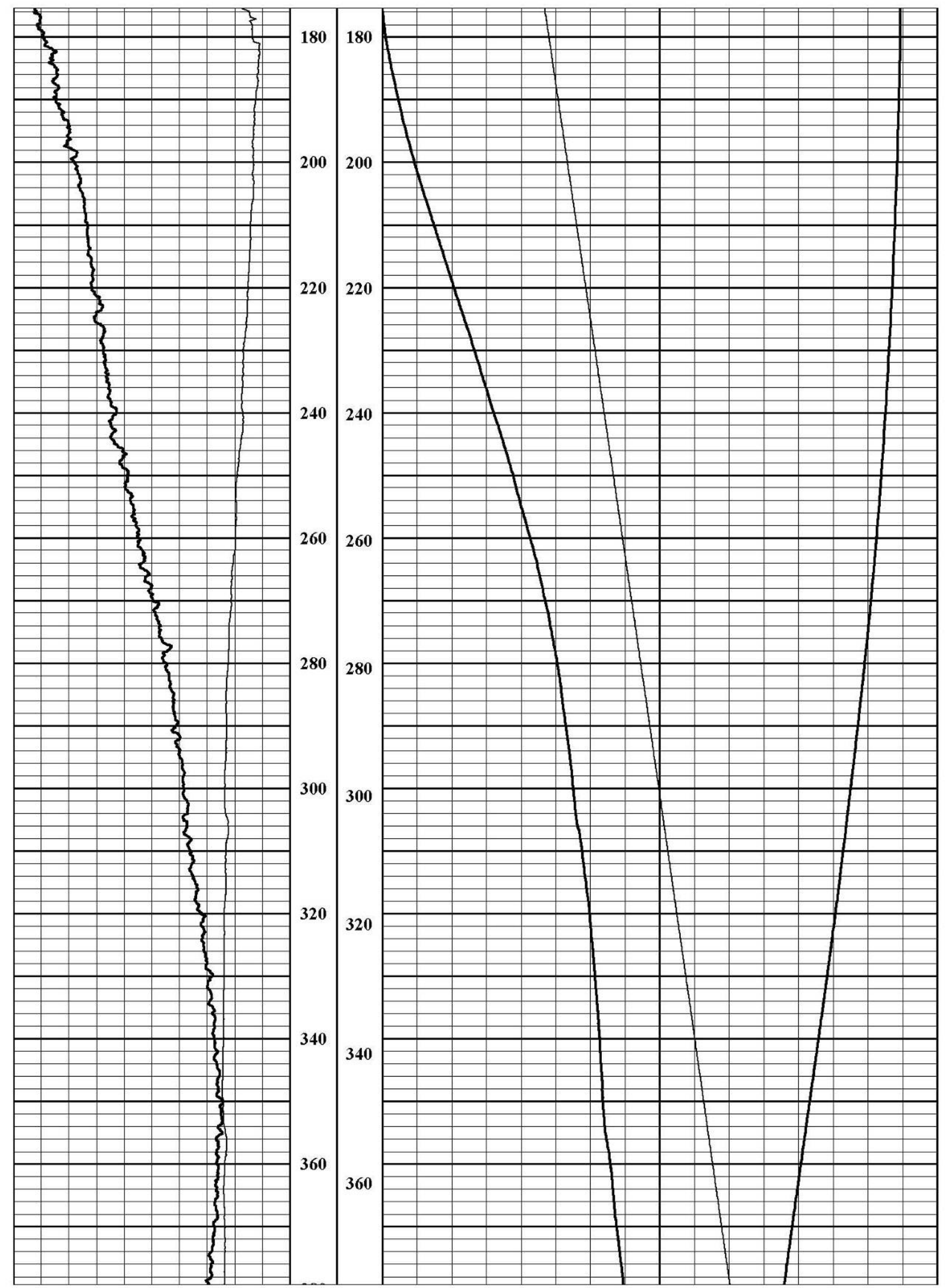




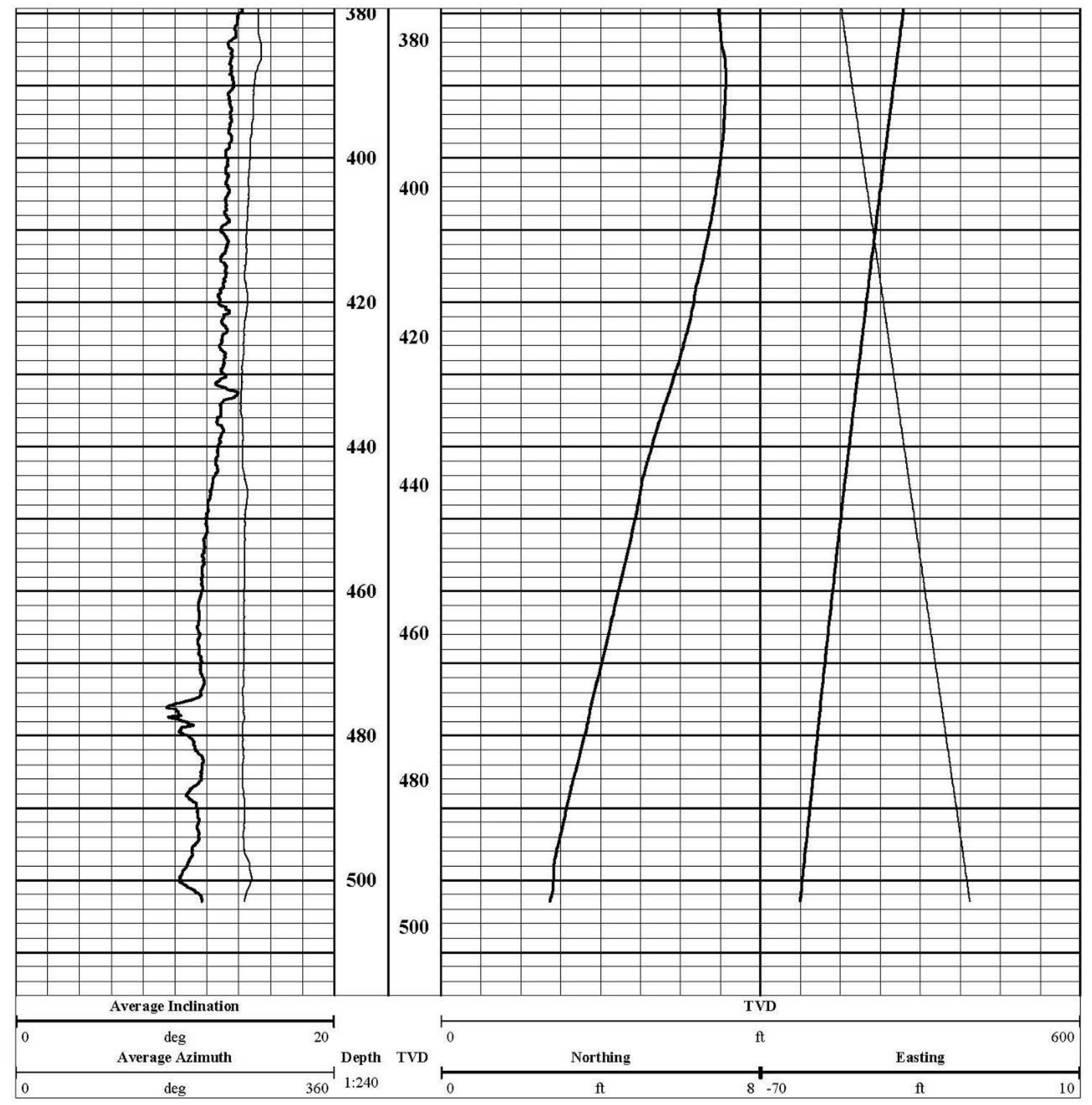




\begin{tabular}{|c|c|c|c|c|c|c|c|c|c|c|c|}
\hline \multicolumn{3}{|c|}{ Deviation Survey for: } & \multicolumn{3}{|c|}{ S. M. Stoller Corporation } & Field: & \multirow{2}{*}{\multicolumn{2}{|c|}{ Gnome-Coach }} & \multicolumn{3}{|c|}{ Date: $\quad 4 / 21 / 2010$} \\
\hline Well: & USGS-4 & & Depth Ref.: & GS & Total Depth: & 503.10 & & & Probe Tyг & $\mathrm{S} / \mathrm{N}:$ & Gyro \\
\hline $\begin{array}{l}\text { Depth } \\
\text { (feet) }\end{array}$ & \begin{tabular}{|c|} 
Inclination \\
(degrees)
\end{tabular} & \begin{tabular}{|c|} 
Bearing \\
(degrees)
\end{tabular} & \begin{tabular}{|c|} 
ClosureL ength \\
(line $\mathrm{ft}$.)
\end{tabular} & $\begin{array}{c}\text { ClosureDist. } \\
\text { (horiz. ft.) }\end{array}$ & $\begin{array}{c}\text { ClosureDepth } \\
\text { (vertical ft.) }\end{array}$ & $\begin{array}{c}\text { Northing } \\
\text { (feet) }\end{array}$ & $\begin{array}{c}\text { Easting } \\
\text { (feet) }\end{array}$ & $\begin{array}{l}\text { TrueDepth } \\
\text { (feet) }\end{array}$ & \begin{tabular}{|c|} 
Dist.Sum \\
(feet)
\end{tabular} & $\begin{array}{l}\text { NorthSum } \\
\text { (feet) }\end{array}$ & $\begin{array}{l}\text { EastSum } \\
\text { (feet) }\end{array}$ \\
\hline 0.0 & -999.250 & 344.069 & 0 & 0.00 & 0.00 & 0.00 & 0.00 & 0.00 & 0.00 & 0.00 & 0.00 \\
\hline 3.0 & 0.277 & 172.769 & 0 & 0.00 & 0.30 & 0.00 & 0.00 & 3.03 & 0.01 & 0.01 & 0.00 \\
\hline 6.0 & 0.313 & 330.944 & 0 & 0.00 & 0.30 & 0.00 & 0.00 & 6.06 & 0.02 & 0.02 & -0.01 \\
\hline 9.0 & 0.293 & 307.358 & 0 & 0.00 & 0.30 & 0.00 & 0.00 & 9.08 & 0.03 & 0.03 & -0.02 \\
\hline 12.0 & 0.275 & 296.482 & 0 & 0.00 & 0.30 & 0.00 & 0.00 & 12.11 & 0.05 & 0.04 & -0.03 \\
\hline 15.0 & 0.262 & 288.529 & 0 & 0.00 & 0.30 & 0.00 & 0.00 & 15.14 & 0.06 & 0.04 & -0.05 \\
\hline 18.0 & 0.324 & 283.267 & 0 & 0.00 & 0.30 & 0.00 & 0.00 & 18.17 & 0.08 & 0.05 & -0.07 \\
\hline 21.0 & 0.339 & 262.194 & 0 & 0.00 & 0.30 & 0.00 & 0.00 & 21.19 & 0.09 & 0.05 & -0.08 \\
\hline 24.0 & 0.321 & 161.768 & 0 & 0.00 & 0.30 & 0.00 & 0.00 & 24.22 & 0.10 & 0.04 & -0.09 \\
\hline 27.0 & 0.322 & 170.103 & 0 & 0.00 & 0.30 & 0.00 & 0.00 & 27.25 & 0.09 & 0.03 & -0.09 \\
\hline 30.0 & 0.295 & 218.338 & 0 & 0.00 & 0.30 & 0.00 & 0.00 & 30.28 & 0.10 & 0.03 & -0.10 \\
\hline 33.0 & 0.303 & 219.358 & 0 & 0.00 & 0.30 & 0.00 & 0.00 & 33.00 & 0.11 & 0.01 & -0.11 \\
\hline 36.0 & 0.311 & 208.928 & 0 & 0.00 & 0.30 & 0.00 & 0.00 & 36.03 & 0.11 & 0.00 & -0.11 \\
\hline 39.0 & 0.266 & 198.089 & 0 & 0.00 & 0.30 & 0.00 & 0.00 & 39.06 & 0.12 & -0.02 & -0.12 \\
\hline 42.0 & 0.285 & 173.151 & 0 & 0.00 & 0.30 & 0.00 & 0.00 & 42.08 & 0.13 & -0.04 & -0.12 \\
\hline 45.0 & 0.428 & 132.015 & 0 & 0.00 & 0.30 & 0.00 & 0.00 & 45.11 & 0.13 & -0.05 & -0.11 \\
\hline 48.0 & 0.418 & 98.950 & 0 & 0.00 & 0.30 & 0.00 & 0.00 & 48.14 & 0.12 & -0.06 & -0.10 \\
\hline 51.0 & 0.240 & 93.031 & 0 & 0.00 & 0.30 & 0.00 & 0.00 & 51.17 & 0.10 & -0.06 & -0.08 \\
\hline 54.0 & 0.253 & 88.396 & 0 & 0.00 & 0.30 & 0.00 & 0.00 & 54.20 & 0.09 & -0.06 & -0.07 \\
\hline 57.0 & 0.386 & 85.966 & 0 & 0.00 & 0.30 & 0.00 & 0.00 & 57.22 & 0.08 & -0.06 & -0.05 \\
\hline 60.0 & 0.329 & 70.542 & 0 & 0.00 & 0.30 & 0.00 & 0.00 & 60.25 & 0.07 & -0.06 & -0.03 \\
\hline 63.0 & 0.354 & 68.212 & 0 & 0.00 & 0.30 & 0.00 & 0.00 & 62.98 & 0.06 & -0.05 & -0.02 \\
\hline 66.0 & 0.415 & 60.338 & 0 & 0.00 & 0.30 & 0.00 & 0.00 & 66.00 & 0.05 & -0.04 & 0.00 \\
\hline 69.0 & 0.351 & 119.527 & 0 & 0.00 & 0.30 & 0.00 & 0.00 & 69.03 & 0.04 & -0.04 & 0.00 \\
\hline 72.0 & 0.280 & 192.690 & 0 & 0.00 & 0.30 & 0.00 & 0.00 & 72.06 & 0.05 & -0.05 & 0.01 \\
\hline 75.0 & 0.299 & 198.404 & 0 & 0.00 & 0.30 & 0.00 & 0.00 & 75.09 & 0.06 & -0.06 & 0.01 \\
\hline 78.0 & 0.351 & 195.798 & 0 & 0.00 & 0.30 & 0.00 & 0.00 & 78.11 & 0.07 & -0.07 & 0.01 \\
\hline 81.0 & 0.375 & 345.487 & 0 & 0.00 & 0.30 & 0.00 & 0.00 & 81.14 & 0.09 & -0.09 & 0.01 \\
\hline 84.0 & 0.302 & 324.353 & 0 & 0.00 & 0.30 & 0.00 & 0.00 & 84.17 & 0.07 & -0.07 & 0.00 \\
\hline 87.0 & 0.232 & 326.457 & 0 & 0.00 & 0.30 & 0.00 & 0.00 & 87.20 & 0.06 & -0.06 & -0.01 \\
\hline 90.0 & 0.276 & 340.680 & 0 & 0.00 & 0.30 & 0.00 & 0.00 & 90.23 & 0.06 & -0.05 & -0.02 \\
\hline 93.0 & 0.246 & 321.613 & 0 & 0.00 & 0.30 & 0.00 & 0.00 & 92.95 & 0.05 & -0.04 & -0.02 \\
\hline 96.0 & 0.286 & 307.194 & 0 & 0.00 & 0.30 & 0.00 & 0.00 & 95.98 & 0.04 & -0.03 & -0.03 \\
\hline 99.0 & 0.274 & 274.181 & 0 & 0.00 & 0.30 & 0.00 & 0.00 & 99.01 & 0.05 & -0.02 & -0.05 \\
\hline 102.0 & 0.280 & 262.660 & 0 & 0.00 & 0.30 & 0.00 & 0.00 & 102.03 & 0.07 & -0.02 & -0.06 \\
\hline 105.0 & 0.282 & 270.494 & 0 & 0.00 & 0.30 & 0.00 & 0.00 & 105.06 & 0.08 & -0.02 & -0.08 \\
\hline 108.0 & 0.306 & 282.500 & 0 & 0.00 & 0.30 & 0.00 & 0.00 & 108.09 & 0.10 & -0.02 & -0.10 \\
\hline 111.0 & 0.358 & 272.444 & 0 & 0.00 & 0.30 & 0.00 & 0.00 & 111.12 & 0.12 & -0.02 & -0.11 \\
\hline 114.0 & 0.342 & 273.551 & 0 & 0.00 & 0.30 & 0.00 & 0.00 & 114.14 & 0.14 & -0.02 & -0.13 \\
\hline 117.0 & 0.398 & 214.262 & 0 & 0.00 & 0.30 & 0.00 & 0.00 & 117.17 & 0.15 & -0.02 & -0.15 \\
\hline 120.0 & 0.240 & 263.156 & 0 & 0.00 & 0.30 & 0.00 & 0.00 & 120.20 & 0.17 & -0.03 & -0.17 \\
\hline 123.0 & \begin{tabular}{l|l|}
0.374 \\
\end{tabular} & 307.983 & 0 & 0.00 & 0.30 & 0.00 & 0.00 & 122.92 & 0.19 & -0.04 & -0.18 \\
\hline 126.0 & 0.481 & 260.847 & 0 & 0.00 & 0.30 & 0.00 & 0.00 & 125.95 & 0.21 & -0.04 & -0.20 \\
\hline 129.0 & 0.530 & 192.505 & 0 & 0.00 & 0.30 & 0.00 & 0.00 & 128.98 & 0.22 & -0.05 & -0.22 \\
\hline 132.0 & 0.429 & 185.622 & 0 & 0.00 & 0.30 & 0.00 & 0.00 & 132.01 & 0.23 & -0.07 & -0.22 \\
\hline 135.0 & 0.633 & 152.478 & 0 & 0.00 & 0.30 & 0.00 & 0.00 & 135.04 & 0.24 & -0.09 & -0.22 \\
\hline 138.0 & 0.674 & 146.115 & 0 & 0.00 & 0.30 & 0.00 & 0.00 & 138.06 & 0.25 & -0.11 & -0.22 \\
\hline 141.0 & 0.574 & 181.103 & 0 & 0.00 & 0.30 & 0.00 & 0.00 & 141.09 & 0.26 & -0.13 & -0.23 \\
\hline 144.0 & 0.635 & 172.891 & 0 & 0.00 & 0.30 & 0.00 & 0.00 & 144.12 & 0.27 & -0.15 & -0.22 \\
\hline 147.0 & 0.629 & 233.297 & 0 & 0.00 & 0.30 & 0.00 & 0.00 & 147.15 & 0.28 & -0.17 & -0.22 \\
\hline 150.0 & 0.842 & 328.096 & 0 & 0.00 & 0.30 & 0.00 & 0.00 & 150.17 & 0.30 & -0.19 & -0.23 \\
\hline 153.0 & 1.038 & 261.636 & 0 & 0.00 & 0.00 & 0.00 & 0.00 & 152.90 & 0.32 & -0.19 & -0.26 \\
\hline 156.0 & 0.844 & 239.013 & 0 & 0.00 & 0.30 & 0.00 & 0.00 & 155.93 & 0.33 & -0.16 & -0.28 \\
\hline 159.0 & 0.575 & 248.084 & 0 & 0.00 & 0.30 & 0.00 & 0.00 & 158.95 & 0.36 & -0.15 & -0.33 \\
\hline 162.0 & 1.154 & 228.271 & 0 & 0.01 & 0.30 & 0.00 & 0.00 & 161.98 & 0.40 & -0.14 & -0.38 \\
\hline 165.0 & 1.473 & 296.170 & 0 & 0.01 & 0.30 & 0.00 & -0.01 & 165.01 & 0.44 & -0.13 & -0.42 \\
\hline 168.0 & 1.645 & 299.158 & 0 & 0.01 & 0.30 & 0.00 & -0.01 & 168.03 & 0.49 & -0.11 & -0.47 \\
\hline 171.0 & 1.211 & 317.069 & 0 & 0.01 & 0.30 & 0.00 & 0.00 & 171.06 & 0.55 & -0.06 & -0.54 \\
\hline
\end{tabular}

Page 1

2010 Groundwater Monitoring and Inspection Report Gnome-Coach, New Mexico 


\begin{tabular}{|c|c|c|c|c|c|c|c|c|c|c|c|}
\hline \multicolumn{3}{|c|}{ Deviation Survey for: } & \multicolumn{3}{|c|}{ S. M. Stoller Corporation } & \multirow{2}{*}{ Field: } & \multirow{2}{*}{\multicolumn{2}{|c|}{ Gnome-Coach }} & \multicolumn{3}{|c|}{ Date: $\quad 4 / 21 / 2010$} \\
\hline Well: & USGS-4 & & Depth Ref.: & GS & Total Depth: & & & & Probe Typ & $\mathrm{S} / \mathrm{N}:$ & Gyro \\
\hline $\begin{array}{l}\text { Depth } \\
\text { (feet) }\end{array}$ & \begin{tabular}{|c|} 
Inclination \\
(degrees)
\end{tabular} & $\begin{array}{c}\text { Bearing } \\
\text { (degrees) }\end{array}$ & $\begin{array}{l}\text { ClosureL ength } \\
\text { (line ff.) }\end{array}$ & $\begin{array}{c}\text { ClosureDist. } \\
\text { (horiz. ft.) }\end{array}$ & $\begin{array}{l}\text { ClosureDepth } \\
\text { (vertical ft.) }\end{array}$ & $\begin{array}{l}\text { Northing } \\
\text { (feet) }\end{array}$ & $\begin{array}{c}\text { Easting } \\
\text { (feet) }\end{array}$ & $\begin{array}{c}\text { TrueDepth } \\
\text { (feet) }\end{array}$ & \begin{tabular}{|c|}
$\begin{array}{c}\text { Dist.Sum } \\
\text { (feet) }\end{array}$
\end{tabular} & $\begin{array}{l}\text { NorthSum } \\
\text { (feet) }\end{array}$ & $\begin{array}{c}\text { EastSum } \\
\text { (feet) }\end{array}$ \\
\hline 174.0 & 1.873 & 269.984 & 0 & \begin{tabular}{r|}
0.01 \\
\end{tabular} & 0.30 & 0.00 & -0.01 & \begin{tabular}{|r|}
174.09 \\
\end{tabular} & 0.61 & -0.02 & -0.61 \\
\hline 177.0 & 2.380 & 316.617 & 0 & 0.01 & 0.30 & 0.01 & -0.01 & 177.11 & 0.68 & 0.03 & -0.68 \\
\hline 180.0 & 2.087 & 324.066 & 0 & 0.01 & 0.30 & 0.01 & -0.01 & 180.14 & 0.77 & 0.09 & -0.76 \\
\hline 183.0 & 1.826 & 322.842 & 0 & 0.01 & 0.30 & 0.01 & -0.01 & 183.16 & 0.87 & 0.20 & -0.85 \\
\hline 186.0 & 3.281 & 319.308 & 0 & 0.02 & 0.30 & 0.01 & -0.01 & 185.88 & 0.99 & 0.30 & -0.94 \\
\hline 189.0 & 2.870 & 317.808 & 0 & 0.02 & 0.30 & 0.01 & -0.01 & 188.91 & 1.12 & 0.41 & -1.05 \\
\hline 192.0 & 3.986 & 310.686 & 0 & 0.02 & 0.30 & 0.01 & -0.02 & 191.93 & 1.28 & 0.53 & -1.17 \\
\hline 195.0 & 3.853 & 314.742 & 0 & 0.02 & 0.30 & 0.01 & -0.01 & 194.95 & 1.48 & 0.67 & -1.31 \\
\hline 198.0 & 4.399 & 311.066 & 0 & 0.02 & 0.30 & 0.02 & -0.02 & 197.97 & 1.68 & 0.81 & -1.47 \\
\hline 201.0 & 4.689 & 309.340 & 0 & 0.02 & 0.30 & 0.02 & -0.02 & 200.99 & 1.91 & 0.96 & -1.65 \\
\hline 204.0 & 4.315 & 317.428 & 0 & 0.02 & 0.30 & 0.02 & -0.02 & 204.01 & 2.15 & 1.13 & -1.84 \\
\hline 207.0 & 5.194 & 309.199 & 0 & 0.03 & 0.30 & 0.02 & -0.02 & 207.02 & 2.41 & 1.30 & -2.03 \\
\hline 210.0 & 5.490 & 309.138 & 0 & 0.03 & 0.30 & 0.02 & -0.02 & 210.04 & 2.68 & 1.47 & -2.24 \\
\hline 213.0 & 5.502 & 309.435 & 0 & 0.03 & 0.30 & 0.02 & -0.02 & 213.05 & 2.96 & 1.65 & -2.46 \\
\hline 216.0 & 5.604 & 306.286 & 0 & 0.03 & 0.30 & 0.02 & -0.02 & 215.76 & 3.22 & 1.80 & -2.67 \\
\hline 219.0 & 5.479 & 307.767 & 0 & 0.03 & 0.30 & 0.02 & -0.02 & 218.78 & 3.52 & 1.98 & -2.91 \\
\hline 222.0 & 6.877 & 303.265 & 0 & 0.04 & 0.30 & 0.02 & -0.03 & 221.79 & 3.82 & 2.15 & -3.15 \\
\hline 225.0 & 5.918 & 304.631 & 0 & 0.03 & 0.30 & 0.02 & -0.03 & 224.80 & 4.15 & 2.34 & -3.43 \\
\hline 228.0 & 6.265 & 301.476 & 0 & 0.03 & 0.30 & 0.02 & -0.03 & 227.81 & 4.48 & 2.52 & -3.71 \\
\hline 231.0 & 6.451 & 300.069 & 0 & 0.03 & 0.30 & 0.02 & -0.03 & 230.82 & 4.81 & 2.68 & -4.00 \\
\hline 234.0 & 6.381 & 302.359 & 0 & 0.03 & 0.30 & 0.02 & -0.03 & 233.82 & 5.16 & 2.84 & -4.30 \\
\hline 237.0 & 6.841 & 298.092 & 0 & 0.04 & 0.30 & 0.02 & -0.03 & 236.83 & 5.51 & 3.01 & -4.62 \\
\hline 240.0 & 7.150 & 297.455 & 0 & 0.04 & 0.30 & 0.02 & -0.03 & 239.83 & 5.88 & 3.18 & -4.95 \\
\hline 243.0 & 7.022 & 303.442 & 0 & 0.04 & 0.30 & 0.02 & -0.03 & 242.84 & 6.25 & 3.36 & -5.28 \\
\hline 246.0 & 7.917 & 296.361 & 0 & 0.04 & 0.30 & 0.02 & -0.04 & 245.54 & 6.59 & 3.51 & -5.58 \\
\hline 249.0 & 7.793 & 293.577 & 0 & 0.04 & 0.30 & 0.02 & -0.04 & 248.54 & 6.99 & 3.67 & -5.95 \\
\hline 252.0 & 8.556 & 287.271 & 0 & 0.04 & 0.30 & 0.01 & -0.04 & 251.54 & 7.41 & 3.82 & -6.35 \\
\hline 255.0 & 8.961 & 287.565 & 0 & 0.05 & 0.30 & 0.01 & -0.04 & 254.53 & 7.84 & 3.96 & -6.76 \\
\hline 258.0 & 8.482 & 289.168 & 0 & 0.04 & 0.30 & 0.01 & -0.04 & 257.52 & 8.29 & 4.12 & -7.19 \\
\hline 261.0 & 8.651 & 287.972 & 0 & 0.05 & 0.30 & 0.01 & -0.04 & 260.52 & 8.74 & 4.27 & -7.63 \\
\hline 264.0 & 9.803 & 286.986 & 0 & 0.05 & 0.30 & 0.01 & -0.05 & 263.50 & 9.22 & 4.41 & -8.09 \\
\hline 267.0 & 9.616 & 284.462 & 0 & 0.05 & 0.30 & 0.01 & -0.05 & 266.49 & 9.69 & 4.53 & -8.56 \\
\hline 270.0 & 10.347 & 283.765 & 0 & 0.05 & 0.30 & 0.01 & -0.05 & 269.47 & 10.19 & 4.65 & -9.06 \\
\hline 273.0 & 10.368 & 279.927 & 0 & 0.05 & 0.30 & 0.01 & -0.05 & 272.45 & 10.71 & 4.77 & -9.59 \\
\hline 276.0 & 10.374 & 280.519 & 0 & 0.05 & 0.30 & 0.01 & -0.05 & 275.13 & 11.19 & 4.86 & -10.07 \\
\hline 279.0 & 10.923 & 279.610 & 0 & 0.06 & 0.30 & 0.01 & -0.06 & 278.10 & 11.73 & 4.96 & -10.63 \\
\hline 282.0 & 11.489 & 277.207 & 0 & 0.06 & 0.30 & 0.01 & -0.06 & 281.07 & 12.28 & 5.05 & -11.20 \\
\hline 285.0 & 11.530 & 276.522 & 0 & 0.06 & 0.30 & 0.01 & -0.06 & 284.04 & 12.85 & 5.12 & -11.78 \\
\hline 288.0 & 11.786 & 276.615 & 0 & 0.06 & 0.30 & 0.01 & -0.06 & 287.01 & 13.42 & 5.19 & -12.38 \\
\hline 291.0 & 11.338 & 274.219 & 0 & 0.06 & 0.30 & 0.00 & -0.06 & 289.97 & 14.01 & 5.26 & -12.99 \\
\hline 294.0 & 11.868 & 275.685 & 0 & 0.06 & 0.30 & 0.01 & -0.06 & 292.94 & 14.61 & 5.33 & -13.60 \\
\hline 297.0 & 12.401 & 276.287 & 0 & 0.06 & 0.30 & 0.01 & -0.06 & 295.90 & 15.21 & 5.40 & -14.22 \\
\hline 300.0 & 12.223 & 275.154 & 0 & 0.06 & 0.30 & 0.01 & -0.06 & 298.85 & 15.83 & 5.45 & -14.86 \\
\hline 303.0 & 12.675 & 275.606 & 0 & 0.07 & 0.30 & 0.01 & -0.07 & 301.81 & 16.45 & 5.50 & -15.50 \\
\hline 306.0 & 12.350 & 282.495 & 0 & 0.00 & 0.00 & 0.00 & 0.00 & 304.47 & 17.09 & 5.58 & -16.15 \\
\hline 309.0 & 12.742 & 276.553 & 0 & 0.07 & 0.30 & 0.01 & -0.07 & 307.43 & 17.66 & 5.67 & -16.73 \\
\hline 312.0 & 12.989 & 275.211 & 0 & 0.07 & 0.30 & 0.01 & -0.07 & 310.38 & 18.31 & 5.74 & -17.39 \\
\hline 315.0 & 13.460 & 276.463 & 0 & 0.07 & 0.29 & 0.01 & -0.07 & 313.33 & 18.96 & 5.80 & -18.05 \\
\hline 318.0 & 13.048 & 275.159 & 0 & 0.07 & 0.29 & 0.01 & -0.07 & 316.28 & 19.63 & 5.87 & -18.74 \\
\hline 321.0 & 13.649 & 273.225 & 0 & 0.07 & 0.29 & 0.00 & -0.07 & 319.22 & 20.31 & 5.92 & -19.43 \\
\hline 324.0 & 13.365 & 275.386 & 0 & 0.07 & 0.29 & 0.01 & -0.07 & 322.16 & 21.01 & 5.97 & -20.14 \\
\hline 327.0 & 13.773 & 275.585 & 0 & 0.07 & 0.29 & 0.01 & -0.07 & 325.10 & 21.70 & 6.02 & -20.85 \\
\hline 330.0 & 14.447 & 272.139 & 0 & 0.07 & 0.29 & 0.00 & -0.07 & 328.04 & 22.42 & 6.07 & -21.58 \\
\hline 333.0 & 14.314 & 273.689 & 0 & 0.07 & 0.29 & 0.00 & -0.07 & 330.98 & 23.13 & 6.11 & -22.31 \\
\hline 336.0 & 14.446 & 274.643 & 0 & 0.07 & 0.29 & 0.01 & -0.07 & 333.91 & 23.86 & 6.15 & -23.05 \\
\hline 339.0 & 14.469 & 272.347 & 0 & 0.07 & 0.29 & 0.00 & -0.07 & 336.55 & 24.52 & 6.18 & -23.72 \\
\hline 342.0 & 14.703 & 271.547 & 0 & 0.08 & 0.29 & 0.00 & -0.08 & 339.48 & 25.25 & 6.22 & -24.47 \\
\hline 345.0 & 14.670 & 272.401 & 0 & 0.08 & 0.29 & 0.00 & -0.08 & 342.41 & 25.99 & 6.25 & -25.23 \\
\hline
\end{tabular}

Page 2 


\begin{tabular}{|c|c|c|c|c|c|c|c|c|c|c|c|}
\hline Deviation & A Survey fo & & S. M. Stoller C & Corporation & & Field: & Gnome-C & Coach & Date: & $21 / 2010$ & \\
\hline Well: & USGS-4 & & Depth Ref.: & GS & Total Depth: & 503.10 & $\mathrm{ft}$ & & Probe Ty & S/N: & Gyro \\
\hline $\begin{array}{l}\text { Depth } \\
\text { (feet) }\end{array}$ & \begin{tabular}{|c|} 
Inclination \\
(degrees)
\end{tabular} & $\begin{array}{c}\text { Bearing } \\
\text { (degrees) }\end{array}$ & $\begin{array}{l}\text { ClosureLength } \\
\text { (line ft.) }\end{array}$ & $\begin{array}{c}\text { ClosureDist. } \\
\text { (horiz. ft.) }\end{array}$ & $\begin{array}{l}\text { ClosureDepth } \\
\text { (vertical ft.) }\end{array}$ & $\begin{array}{c}\text { Northing } \\
\text { (feet) }\end{array}$ & $\begin{array}{c}\text { Easting } \\
\text { (feet) }\end{array}$ & $\begin{array}{l}\text { TrueDepth } \\
\text { (feet) }\end{array}$ & $\begin{array}{c}\text { Dist.Sum } \\
\text { (feet) }\end{array}$ & $\begin{array}{l}\text { NorthSum } \\
\text { (feet) }\end{array}$ & $\begin{array}{c}\text { EastSum } \\
\text { (feet) }\end{array}$ \\
\hline 348.0 & 14.832 & 270.608 & 0 & \begin{tabular}{|c|}
0.08 \\
\end{tabular} & 0.29 & 0.00 & \begin{tabular}{|l|}
-0.08 \\
\end{tabular} & 345.34 & 26.74 & 6.28 & -26.00 \\
\hline 351.0 & 15.050 & 272.328 & 0 & 0.08 & 0.29 & 0.00 & -0.08 & 348.26 & 27.50 & 6.30 & -26.77 \\
\hline 354.0 & 15.053 & 275.376 & 0 & 0.08 & 0.29 & 0.01 & -0.08 & 351.19 & 28.26 & 6.34 & -27.54 \\
\hline 357.0 & 14.794 & 279.498 & 0 & 0.08 & 0.29 & 0.01 & -0.08 & 354.11 & 29.02 & 6.42 & -28.30 \\
\hline 360.0 & 14.799 & 276.347 & 0 & 0.08 & 0.29 & 0.01 & -0.08 & 357.04 & 29.78 & 6.51 & -29.06 \\
\hline 363.0 & 14.149 & 272.701 & 0 & 0.07 & 0.29 & 0.00 & -0.07 & 359.97 & 30.54 & 6.57 & -29.82 \\
\hline 366.0 & 14.406 & 273.285 & 0 & 0.07 & 0.29 & 0.00 & -0.07 & 362.90 & 31.28 & 6.61 & -30.58 \\
\hline 369.0 & 14.633 & 275.442 & 0 & 0.08 & 0.29 & 0.01 & -0.08 & 365.54 & 31.96 & 6.66 & -31.26 \\
\hline 372.0 & 14.409 & 273.344 & 0 & 0.07 & 0.29 & 0.00 & -0.07 & 368.47 & 32.70 & 6.73 & -32.00 \\
\hline 375.0 & 14.040 & 277.447 & 0 & 0.07 & 0.29 & 0.01 & -0.07 & 371.40 & 33.44 & 6.79 & -32.74 \\
\hline 378.0 & 14.568 & 275.631 & 0 & 0.08 & 0.29 & 0.01 & -0.08 & 374.34 & 34.17 & 6.85 & -33.48 \\
\hline 381.0 & 14.164 & 273.614 & 0 & 0.07 & 0.29 & 0.00 & \begin{tabular}{l|}
-0.07 \\
\end{tabular} & 377.27 & 34.90 & 6.91 & -34.21 \\
\hline 384.0 & 13.389 & 271.283 & 0 & 0.07 & 0.29 & 0.00 & -0.07 & 380.21 & 35.61 & 6.96 & -34.92 \\
\hline 387.0 & 13.657 & 269.545 & 0 & 0.07 & 0.29 & 0.00 & -0.07 & 383.16 & 36.31 & 7.05 & -35.62 \\
\hline 390.0 & 13.689 & 267.063 & 0 & 0.07 & 0.29 & 0.00 & -0.07 & 386.10 & 37.00 & 7.06 & -36.32 \\
\hline 393.0 & 13.766 & 270.166 & 0 & 0.07 & 0.29 & 0.00 & -0.07 & 389.05 & 37.68 & 7.04 & -37.02 \\
\hline 396.0 & 13.474 & 265.178 & 0 & 0.07 & 0.29 & -0.01 & -0.07 & 391.99 & 38.36 & 7.02 & -37.72 \\
\hline 399.0 & 13.094 & 264.317 & 0 & 0.07 & 0.29 & -0.01 & -0.07 & 394.64 & 38.97 & 6.97 & -38.35 \\
\hline 402.0 & 13.216 & 261.137 & 0 & 0.07 & 0.29 & -0.01 & -0.07 & 397.59 & 39.63 & 6.90 & -39.03 \\
\hline 405.0 & 13.340 & 265.072 & 0 & 0.07 & 0.29 & -0.01 & -0.07 & 400.53 & 40.29 & 6.82 & -39.71 \\
\hline 408.0 & 12.882 & 262.226 & 0 & 0.07 & 0.30 & -0.01 & -0.07 & 403.48 & 40.95 & 6.73 & -40.39 \\
\hline 411.0 & 13.249 & 259.016 & 0 & 0.07 & 0.29 & -0.01 & -0.07 & 406.43 & 41.59 & 6.62 & -41.06 \\
\hline 414.0 & 12.883 & 261.366 & 0 & 0.07 & 0.30 & -0.01 & -0.07 & 409.38 & 42.24 & 6.51 & -41.73 \\
\hline 417.0 & 12.813 & 259.741 & 0 & 0.07 & 0.30 & -0.01 & -0.07 & 412.33 & 42.88 & 6.37 & -42.40 \\
\hline 420.0 & 12.830 & 262.486 & 0 & 0.07 & 0.30 & -0.01 & \begin{tabular}{|c|}
-0.07 \\
\end{tabular} & 415.28 & 43.51 & 6.27 & -43.06 \\
\hline 423.0 & 12.924 & 258.589 & 0 & 0.07 & 0.30 & -0.01 & -0.07 & 418.23 & 44.15 & 6.16 & -43.72 \\
\hline 426.0 & 12.617 & 260.270 & 0 & 0.07 & 0.30 & -0.01 & -0.06 & 421.18 & 44.79 & 6.01 & -44.38 \\
\hline 429.0 & 12.790 & 251.839 & 0 & 0.07 & 0.30 & -0.02 & -0.06 & 423.84 & 45.36 & 5.87 & -44.97 \\
\hline 432.0 & 13.237 & 258.436 & 0 & 0.07 & 0.29 & -0.01 & -0.07 & 426.79 & 45.97 & 5.70 & -45.62 \\
\hline 435.0 & 12.897 & 253.778 & 0 & 0.07 & 0.30 & -0.02 & -0.06 & 429.73 & 46.62 & 5.51 & -46.29 \\
\hline 438.0 & 12.910 & 257.927 & 0 & 0.07 & 0.30 & -0.01 & -0.07 & 432.68 & 47.23 & 5.34 & -46.93 \\
\hline 441.0 & 12.712 & 254.563 & 0 & 0.07 & 0.30 & -0.02 & -0.06 & 435.64 & 47.86 & 5.19 & -47.57 \\
\hline 444.0 & 12.464 & 256.499 & 0 & 0.06 & 0.30 & -0.02 & -0.06 & 438.59 & 48.47 & 5.03 & -48.21 \\
\hline 447.0 & 12.238 & 262.295 & 0 & 0.06 & 0.30 & -0.01 & -0.06 & 441.55 & 49.09 & 4.93 & -48.84 \\
\hline 450.0 & 12.105 & 259.105 & 0 & 0.06 & 0.30 & -0.01 & -0.06 & 444.51 & 49.69 & 4.82 & -49.46 \\
\hline 453.0 & 11.764 & 257.425 & 0 & 0.06 & 0.30 & -0.01 & -0.06 & 447.47 & 50.29 & 4.70 & -50.07 \\
\hline 456.0 & 11.946 & 258.022 & 0 & 0.06 & 0.30 & -0.01 & -0.06 & 450.44 & 50.87 & 4.57 & -50.67 \\
\hline 459.0 & 11.797 & 257.931 & 0 & 0.00 & 0.00 & 0.00 & 0.00 & 453.11 & 51.45 & 4.45 & -51.26 \\
\hline 462.0 & 11.407 & 258.089 & 0 & 0.06 & 0.30 & -0.01 & -0.06 & 456.07 & 51.98 & 4.33 & -51.80 \\
\hline 465.0 & 11.536 & 259.220 & 0 & 0.06 & 0.30 & -0.01 & -0.06 & 459.04 & 52.55 & 4.20 & -52.38 \\
\hline 468.0 & 11.609 & 257.269 & 0 & 0.06 & 0.30 & -0.01 & -0.06 & 462.01 & 53.12 & 4.07 & -52.96 \\
\hline 471.0 & 11.717 & 256.936 & 0 & 0.06 & 0.30 & -0.01 & -0.06 & 464.97 & 53.70 & 3.94 & -53.55 \\
\hline \begin{tabular}{l|}
474.0 \\
\end{tabular} & 11.618 & 256.892 & 0 & 0.06 & 0.30 & -0.01 & -0.06 & 467.94 & 54.28 & 3.81 & -54.15 \\
\hline 477.0 & 9.756 & 260.667 & 0 & 0.05 & 0.30 & -0.01 & -0.05 & 470.91 & 54.82 & 3.68 & -54.69 \\
\hline 480.0 & 11.127 & 247.684 & 0 & 0.06 & 0.30 & -0.02 & -0.05 & 473.89 & 55.33 & 3.56 & -55.22 \\
\hline 483.0 & 11.718 & 255.083 & 0 & 0.06 & 0.30 & -0.02 & -0.06 & 476.86 & 55.89 & 3.42 & -55.78 \\
\hline 486.0 & 11.503 & 256.181 & 0 & 0.06 & 0.30 & -0.01 & -0.06 & 479.82 & 56.47 & 3.27 & -56.38 \\
\hline 489.0 & 11.391 & 255.701 & 0 & 0.06 & 0.30 & -0.01 & -0.06 & 482.79 & 57.02 & 3.14 & -56.93 \\
\hline 492.0 & 11.654 & 259.803 & 0 & 0.06 & 0.30 & -0.01 & -0.06 & 485.76 & 57.60 & 3.03 & -57.52 \\
\hline 495.0 & 11.255 & 255.699 & 0 & 0.06 & 0.30 & -0.01 & -0.06 & 488.73 & 58.17 & 2.90 & -58.10 \\
\hline 498.0 & 10.731 & 267.519 & 0 & 0.06 & 0.30 & 0.00 & -0.06 & 491.70 & 58.73 & 2.79 & -58.66 \\
\hline 501.0 & 11.166 & 267.771 & 0 & 0.06 & 0.30 & 0.00 & -0.06 & 494.68 & 59.27 & 2.75 & -59.20 \\
\hline 503.1 & -999.250 & -999.250 & 0 & 0.30 & 0.05 & 0.05 & 0.29 & 496.51 & 59.67 & 2.68 & -59.61 \\
\hline
\end{tabular}

Page 3

2010 Groundwater Monitoring and Inspection Report Gnome-Coach, New Mexico 


\begin{tabular}{|c|c|c|c|c|c|c|c|c|c|c|c|}
\hline \multicolumn{3}{|c|}{ Deviation Survey for: } & \multicolumn{3}{|c|}{ S. M. Stoller Corporation } & Field: & \multicolumn{2}{|c|}{ Gnome-Coach } & \multicolumn{3}{|c|}{ Date: $\quad 4 / 21 / 2010$} \\
\hline Well: & USGS-4 & & Depth Ref.: & GS & Total Depth: & 503.10 & & & Probe Ty & $\mathrm{e}, \mathrm{S} / \mathrm{N}:$ & Gyro \\
\hline $\begin{array}{l}\text { Depth } \\
\text { (feet) }\end{array}$ & \begin{tabular}{|c|} 
Inclination \\
(degrees)
\end{tabular} & $\begin{array}{c}\text { Bearing } \\
\text { (degrees) }\end{array}$ & $\begin{array}{l}\text { ClosureLength } \\
\text { (line ff.) }\end{array}$ & $\begin{array}{c}\text { ClosureDist. } \\
\text { (horiz. ft.) }\end{array}$ & \begin{tabular}{|c|}
$\begin{array}{c}\text { ClosureDepth } \\
\text { (vertical ft.) }\end{array}$ \\
\end{tabular} & $\begin{array}{l}\text { Northing } \\
\text { (feet) }\end{array}$ & $\begin{array}{c}\begin{array}{c}\text { Easting } \\
\text { (feet) }\end{array} \\
\end{array}$ & $\begin{array}{l}\text { TrueDepth } \\
\text { (feet) }\end{array}$ & $\begin{array}{c}\begin{array}{c}\text { Dist.Sum } \\
\text { (feet) }\end{array} \\
\end{array}$ & $\begin{array}{c}\text { NorthSum } \\
\text { (feet) }\end{array}$ & 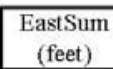 \\
\hline \multicolumn{12}{|c|}{ Definitions } \\
\hline \multicolumn{12}{|c|}{ Bearing = Azimuth Degrees from Magnetic North (Raw Data) } \\
\hline \multicolumn{12}{|c|}{ ClosureDistance $=$ Horizontal Feet Between Each Station } \\
\hline \multicolumn{12}{|c|}{ ClosureDepth $=$ Vertical Feet Between Each Interval } \\
\hline \multicolumn{12}{|c|}{$\begin{aligned} \text { Northing } & =\text { North/South Component of Horizontal Distance Between Each Station }(\text { Negative }=\text { South) } \\
& (\text { Closure Dist. }) \times \cos (\text { Bearing })\end{aligned}$} \\
\hline \multicolumn{12}{|c|}{$\begin{aligned} \text { Easting }= & \text { East/West Component of Horizontal Distance Between Each Station (Negative }=\text { West }) \\
& \text { (Closure Dist.) } x \sin (\text { Bearing) }\end{aligned}$} \\
\hline \multicolumn{12}{|c|}{ TrueDepth $=$ Vertical Depth from the Surface to This Station } \\
\hline \multicolumn{12}{|c|}{ DistanceSum = Horizontal Distance from Wellhead to this Station } \\
\hline \multicolumn{12}{|c|}{$\begin{array}{l}\text { NorthSum }=\text { North/South Component of Horizontal Distance from the Wellhead to This Station (Negative }=\text { South) } \\
\text { Running Sum of Northing }\end{array}$} \\
\hline \multicolumn{12}{|c|}{$\begin{array}{l}\text { EastSum }=\text { East/West Component of Horizontal Distance from the Wellhead to This Station (Negative = West) } \\
\text { Running Sum of Easting }\end{array}$} \\
\hline
\end{tabular}

Page 4 
Deviation Survey for:

Well: USGS-4
S. M. Stoller Corporation Depth Ref.: GS
Field: Gnome-Coach Total Deptl $\quad 503.10 \mathrm{ft}$
Date: $\quad 4 / 21 / 2010$

Probe Type, S/N: Gyro
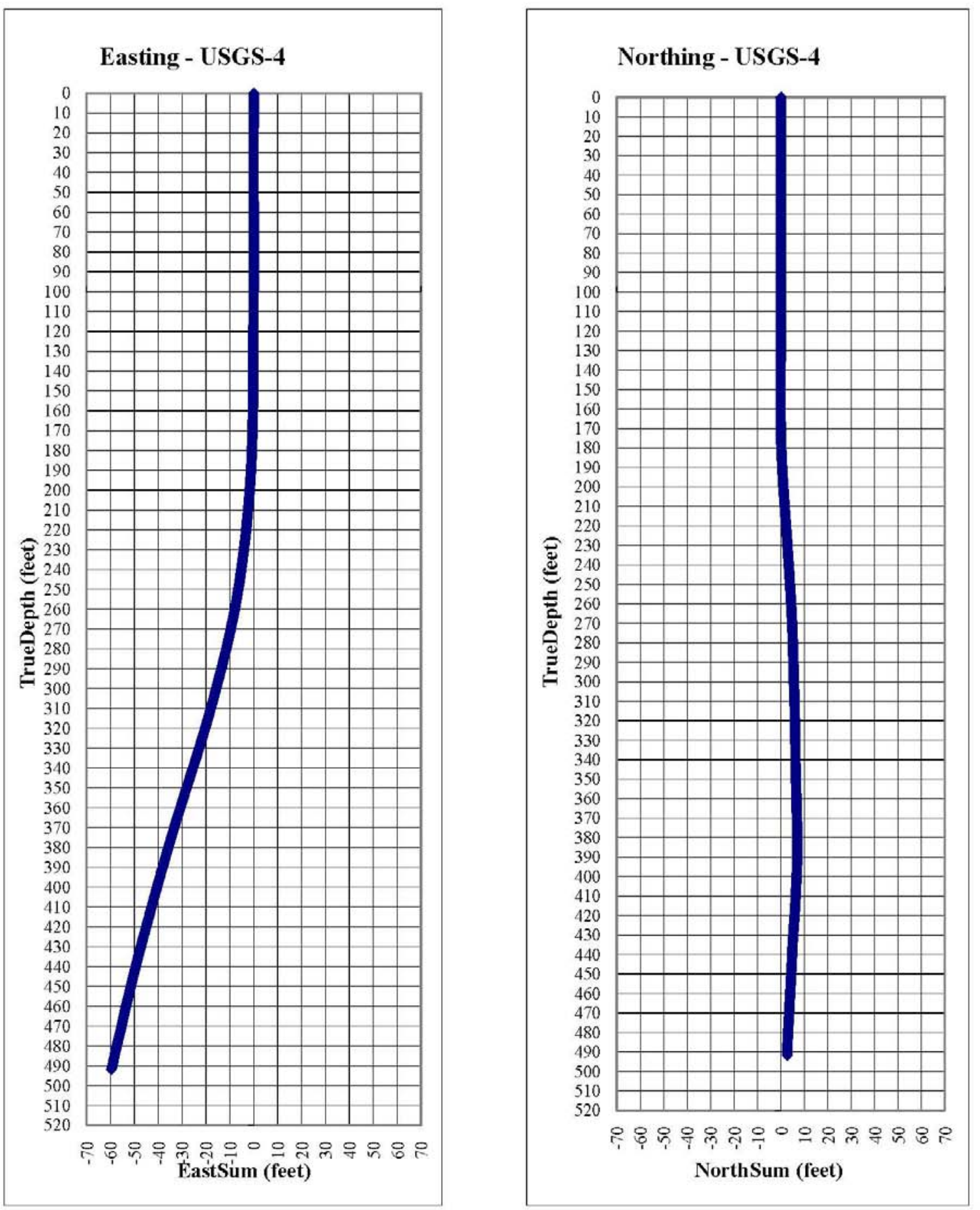

Orientations are with respect to Magnetic North 
Deviation Survey for:

Well: USGS-4
S. M. Stoller Corporation Depth Ref.: GS
Field: Total Deptl $503.10 \mathrm{ft}$
Date: $\quad 4 / 21 / 2010$

Probe Type, S/N: Gyro

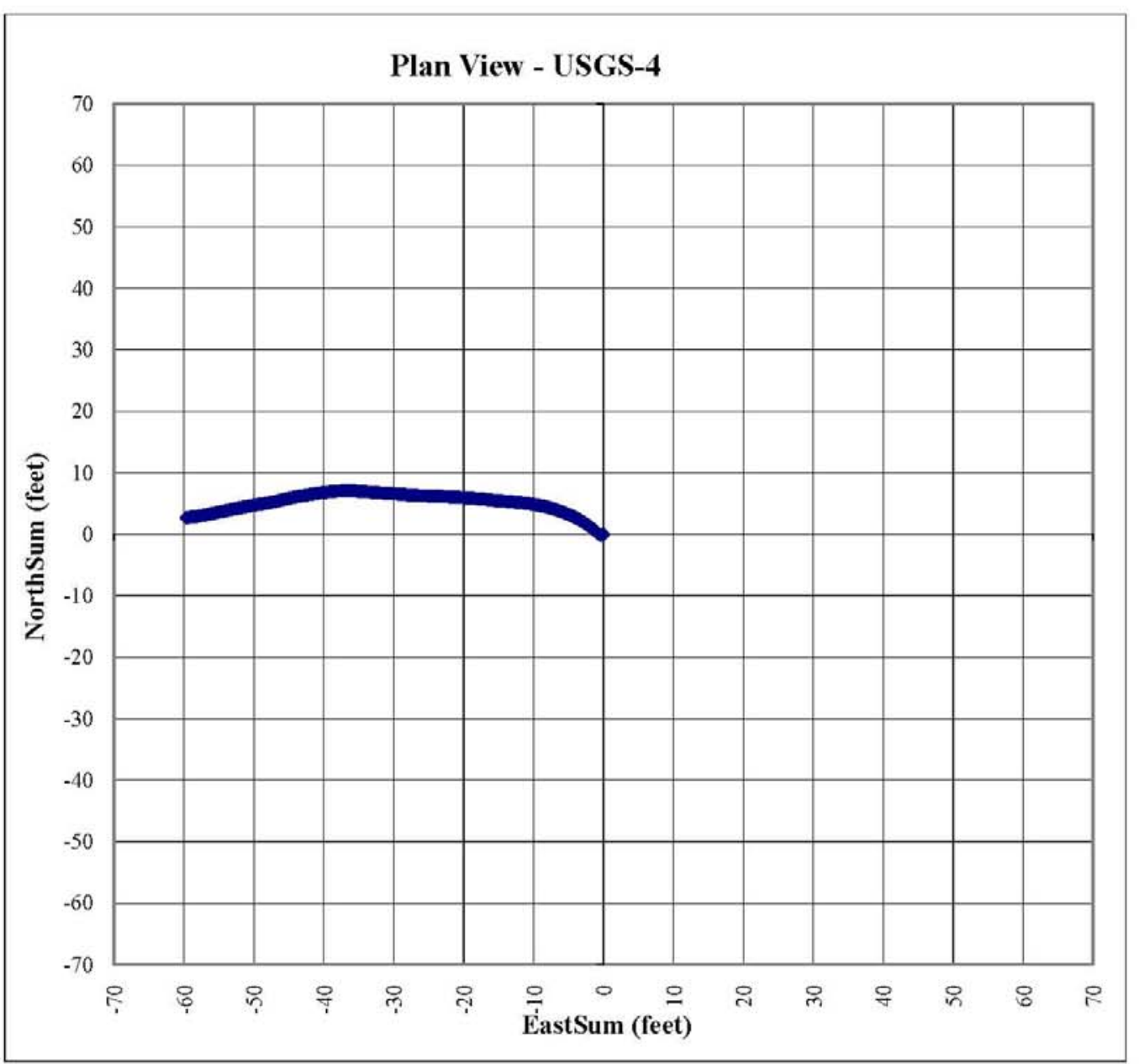

Orientations are with respect to Magnetic North 


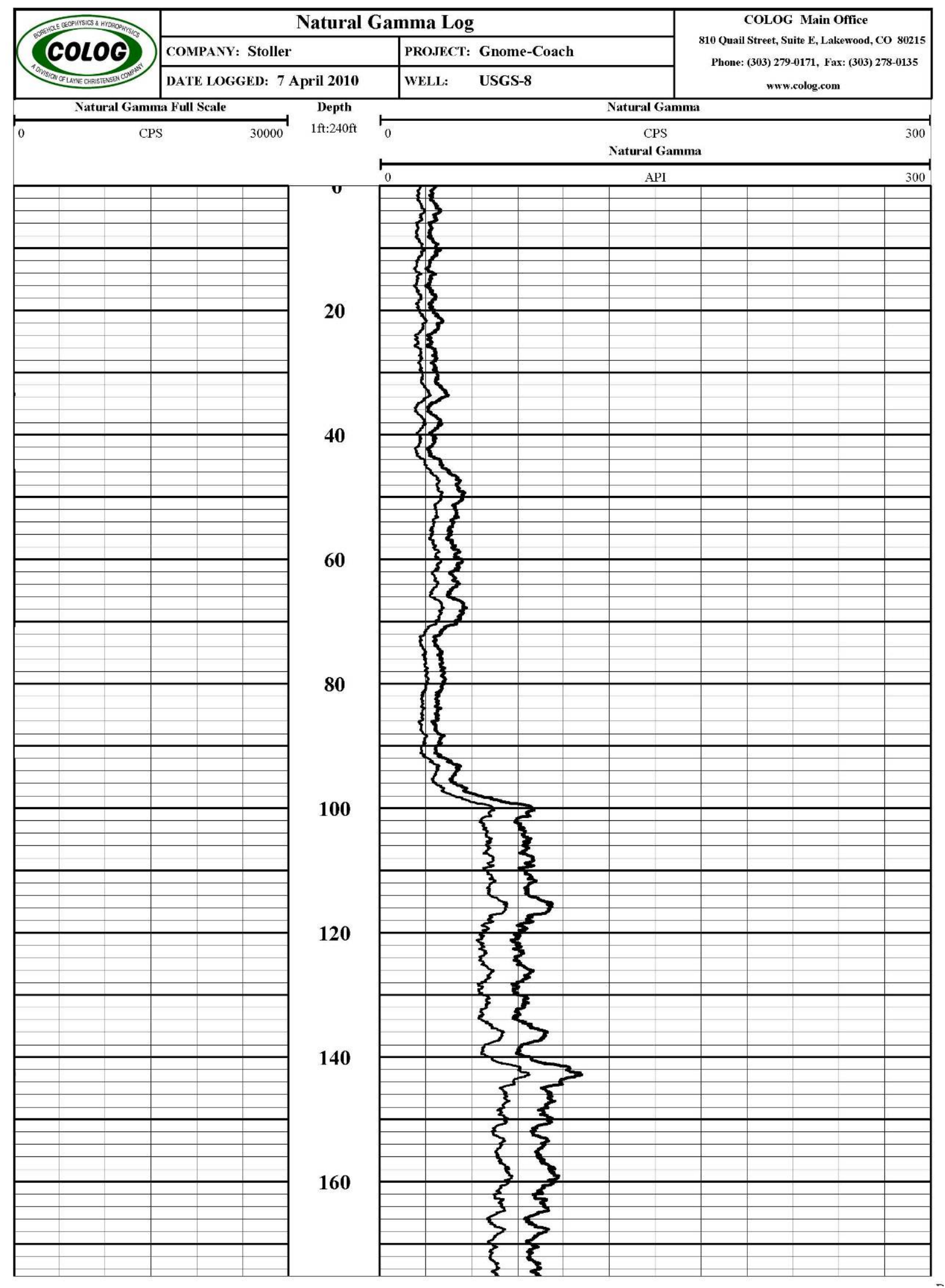



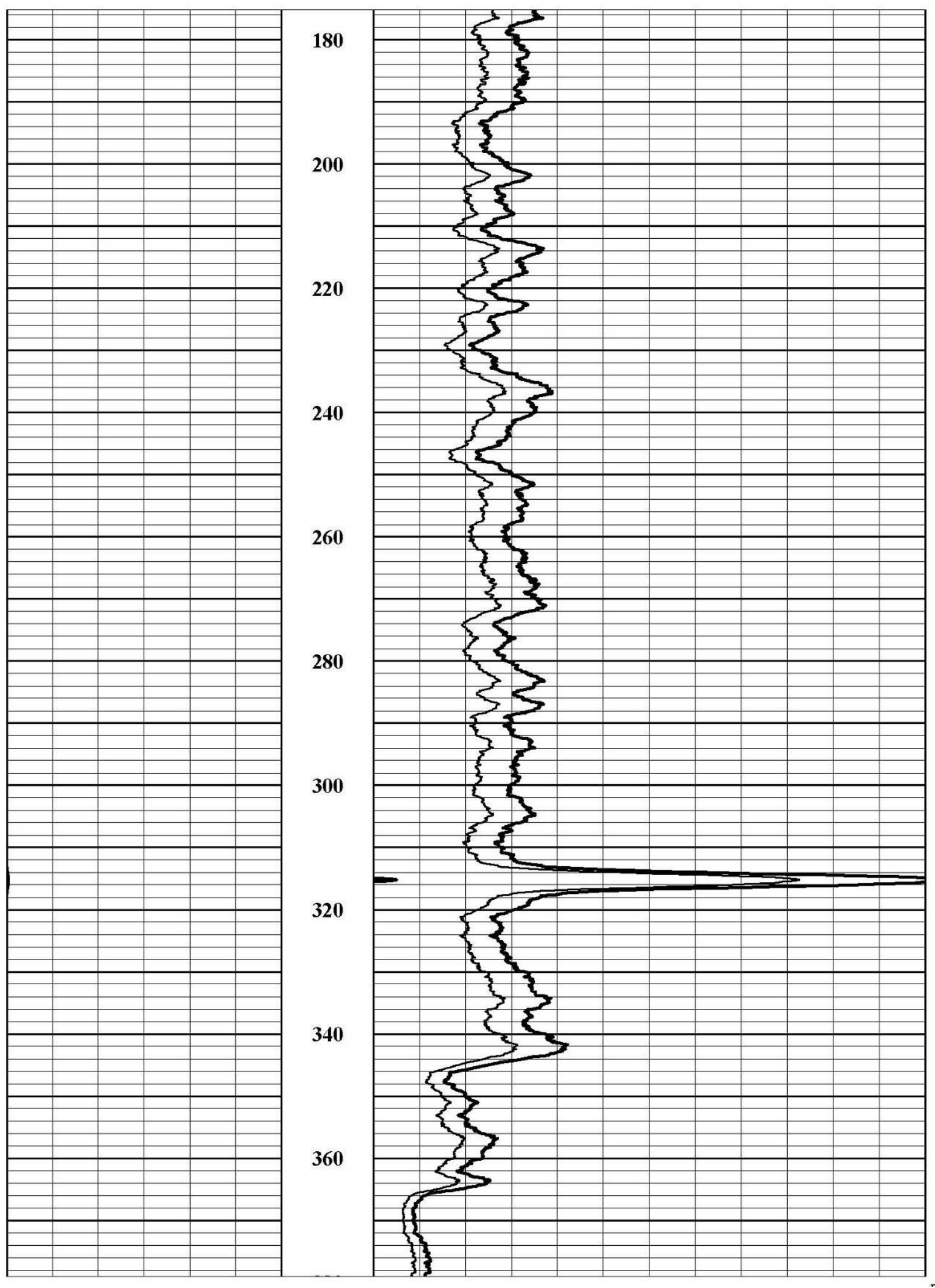


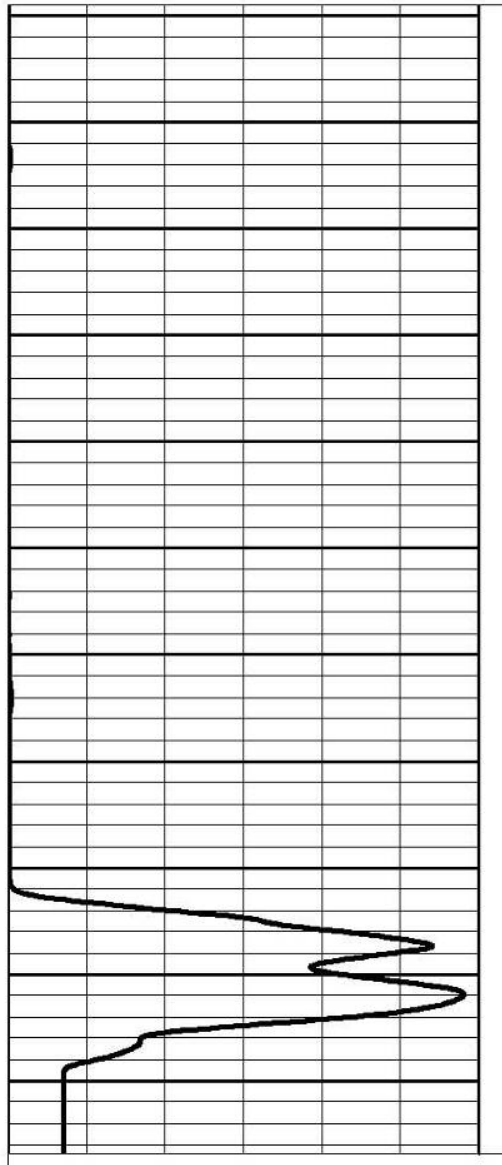

Natural Gamma Full Scale CPS
380

400

420

460

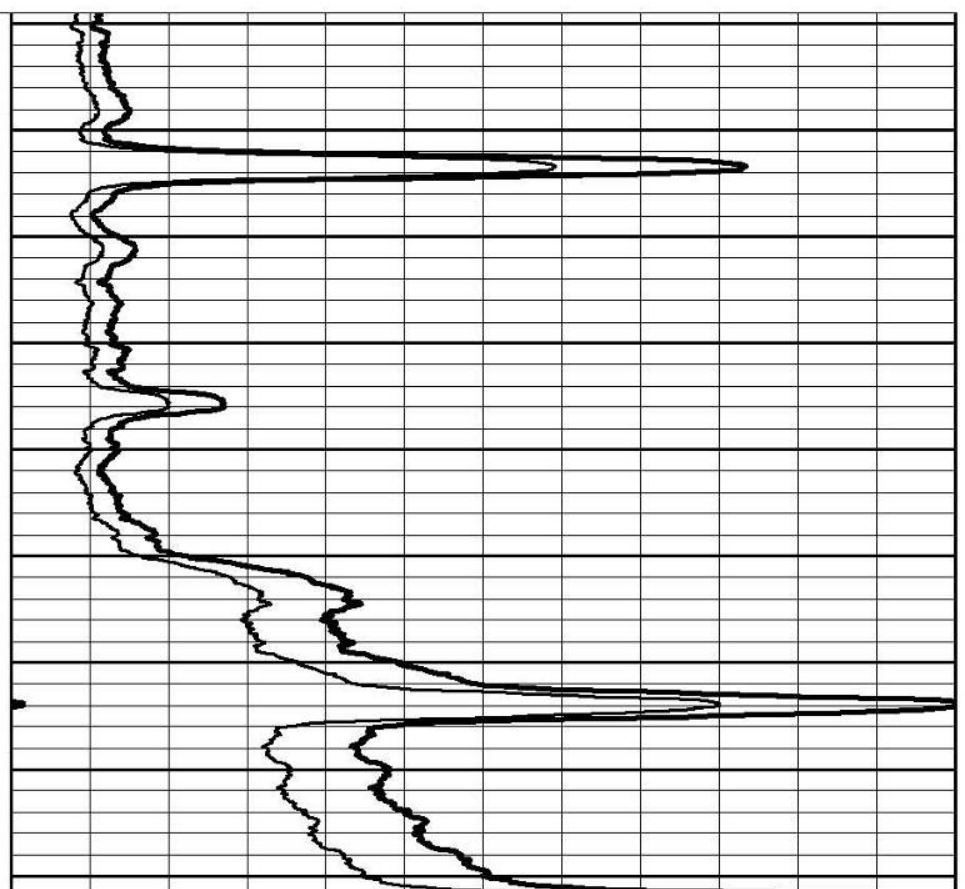

480

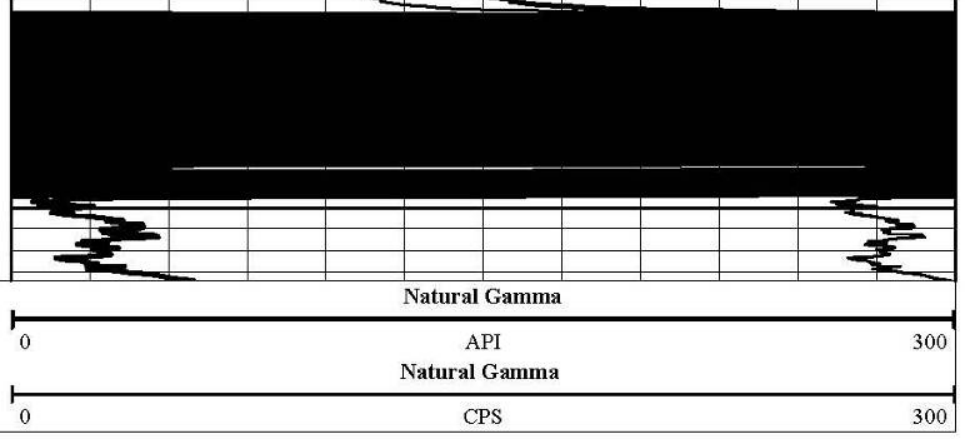




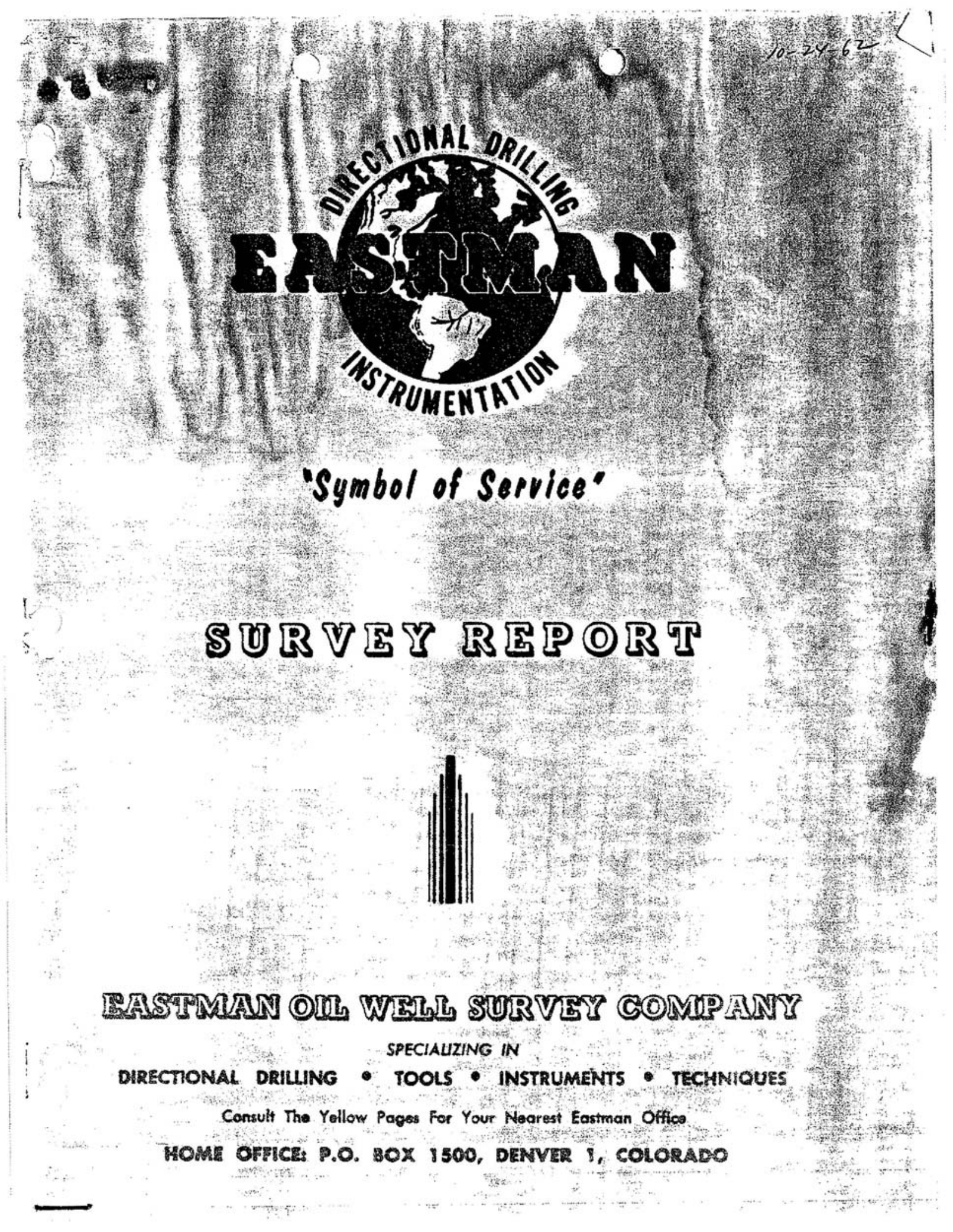




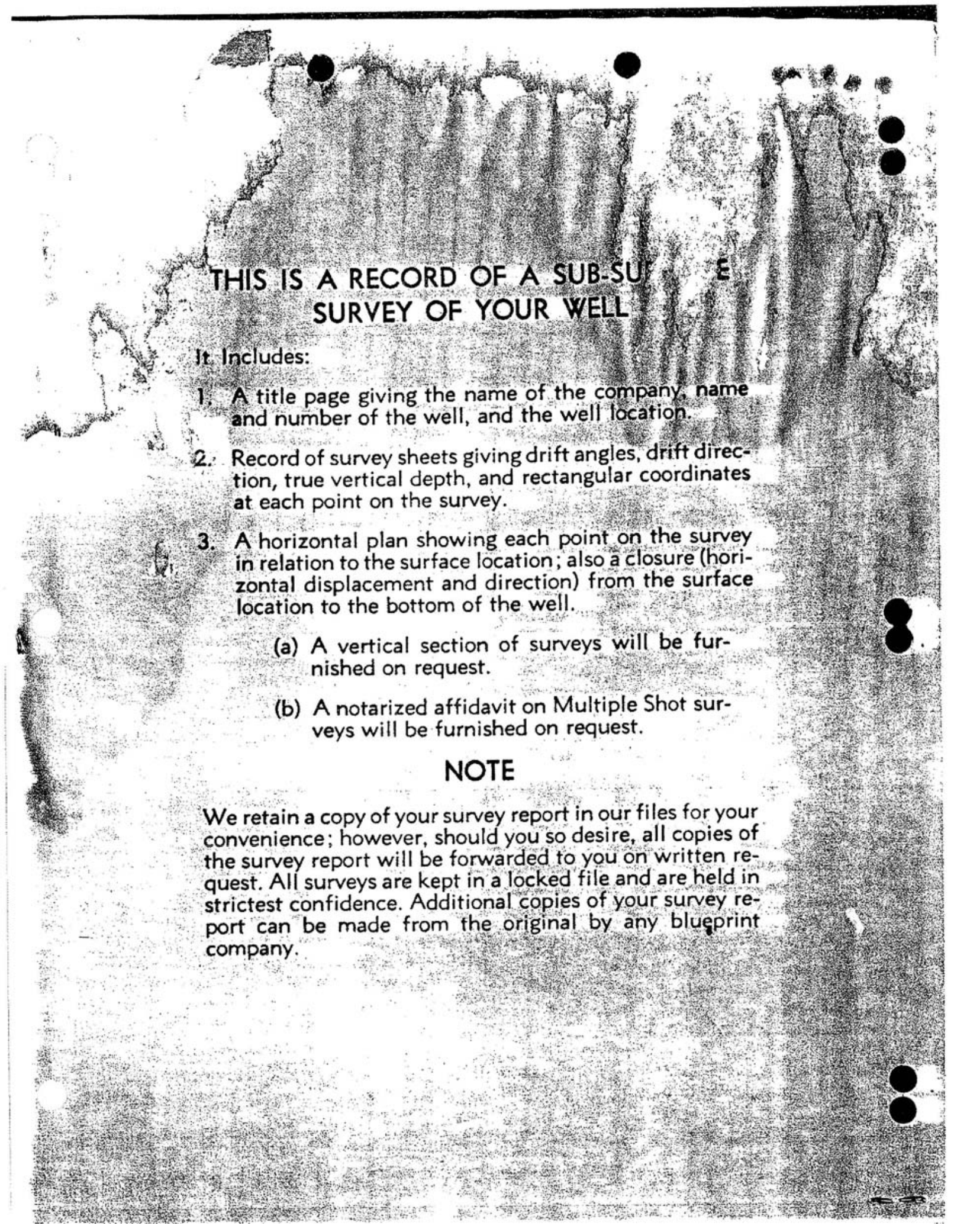




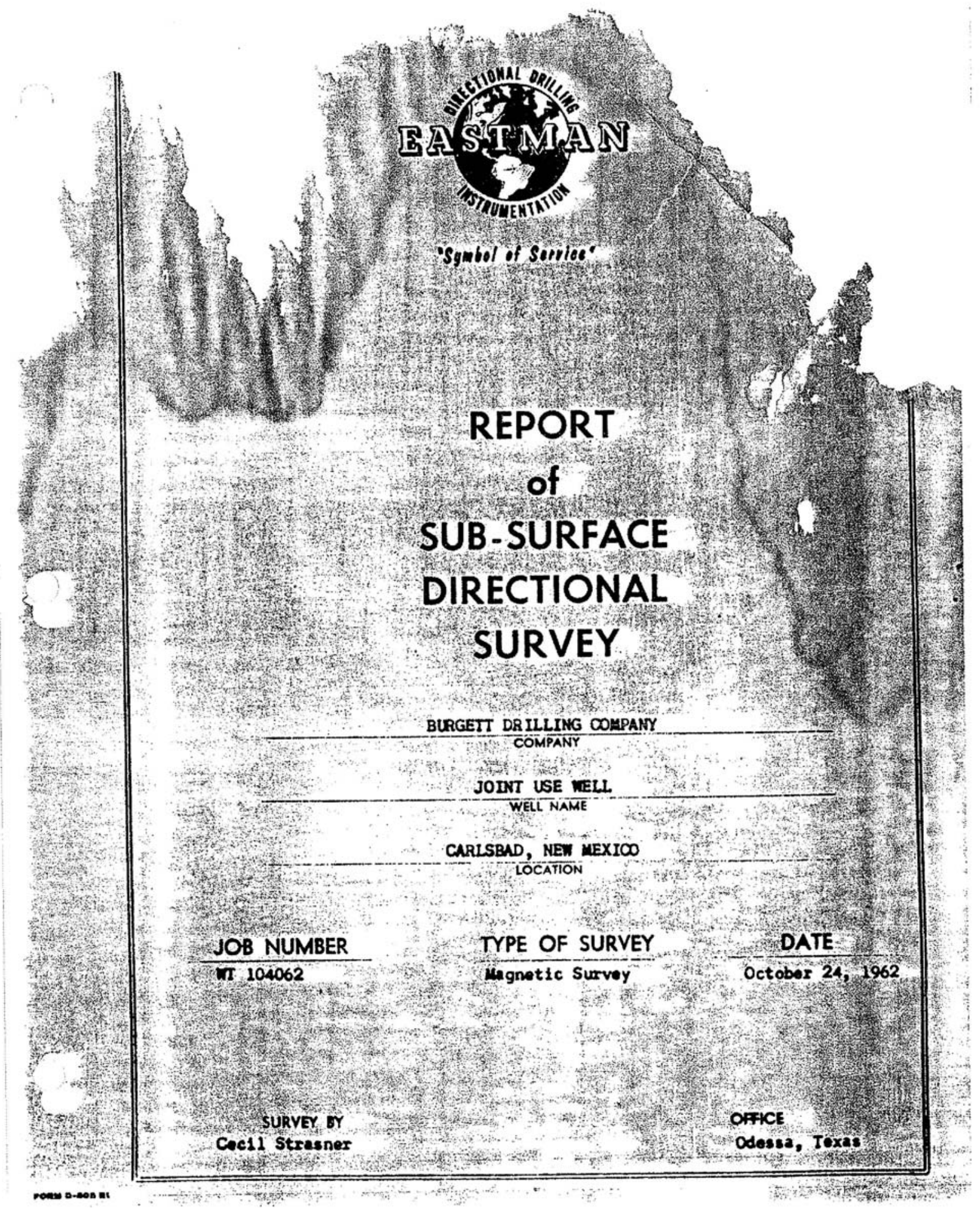




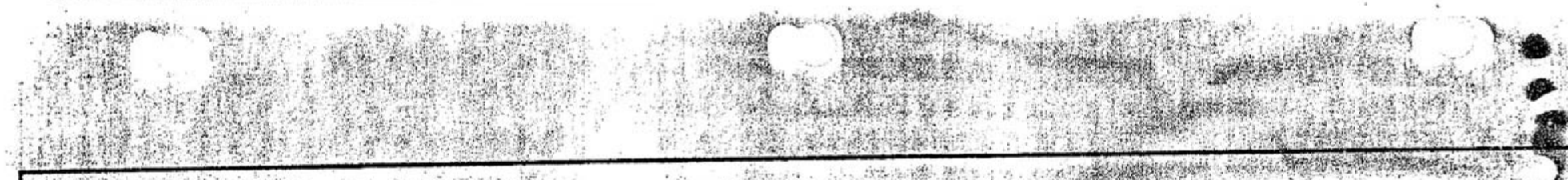

RECORD OF SURVEY

a.t.

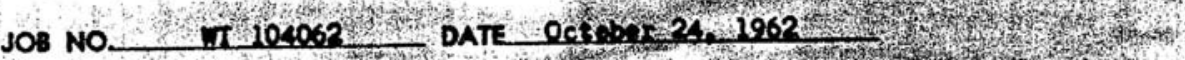

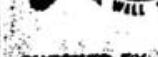

crenerom

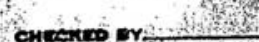

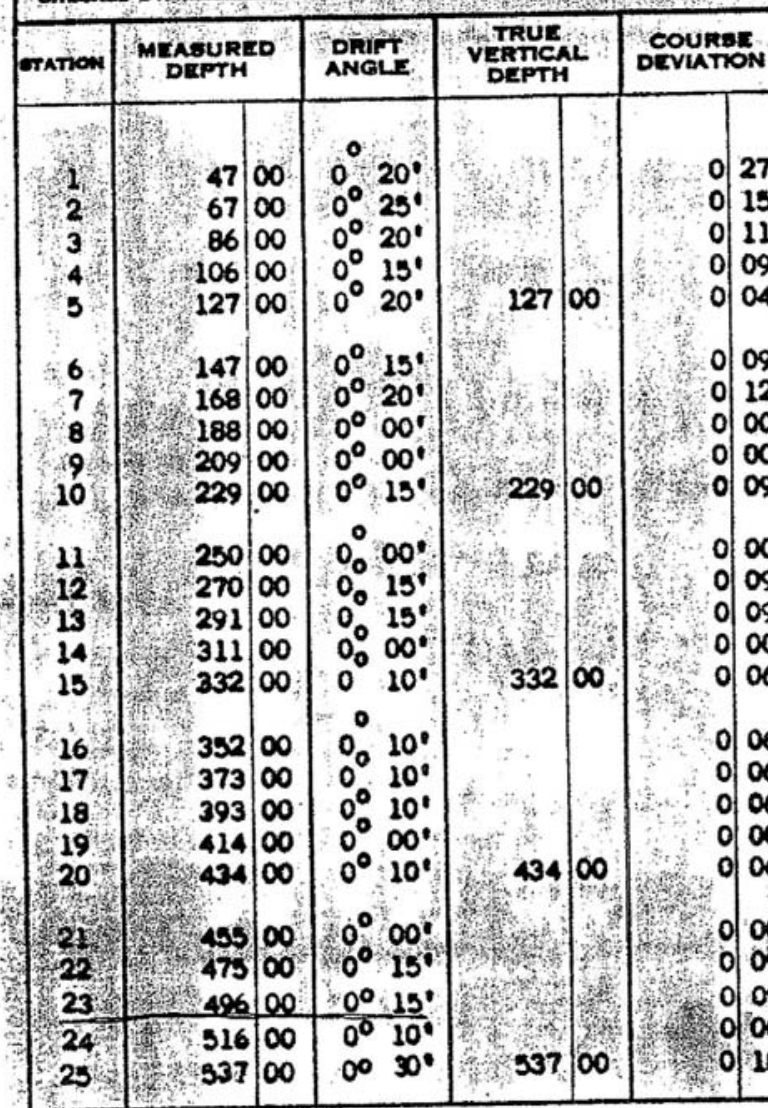

nim no.

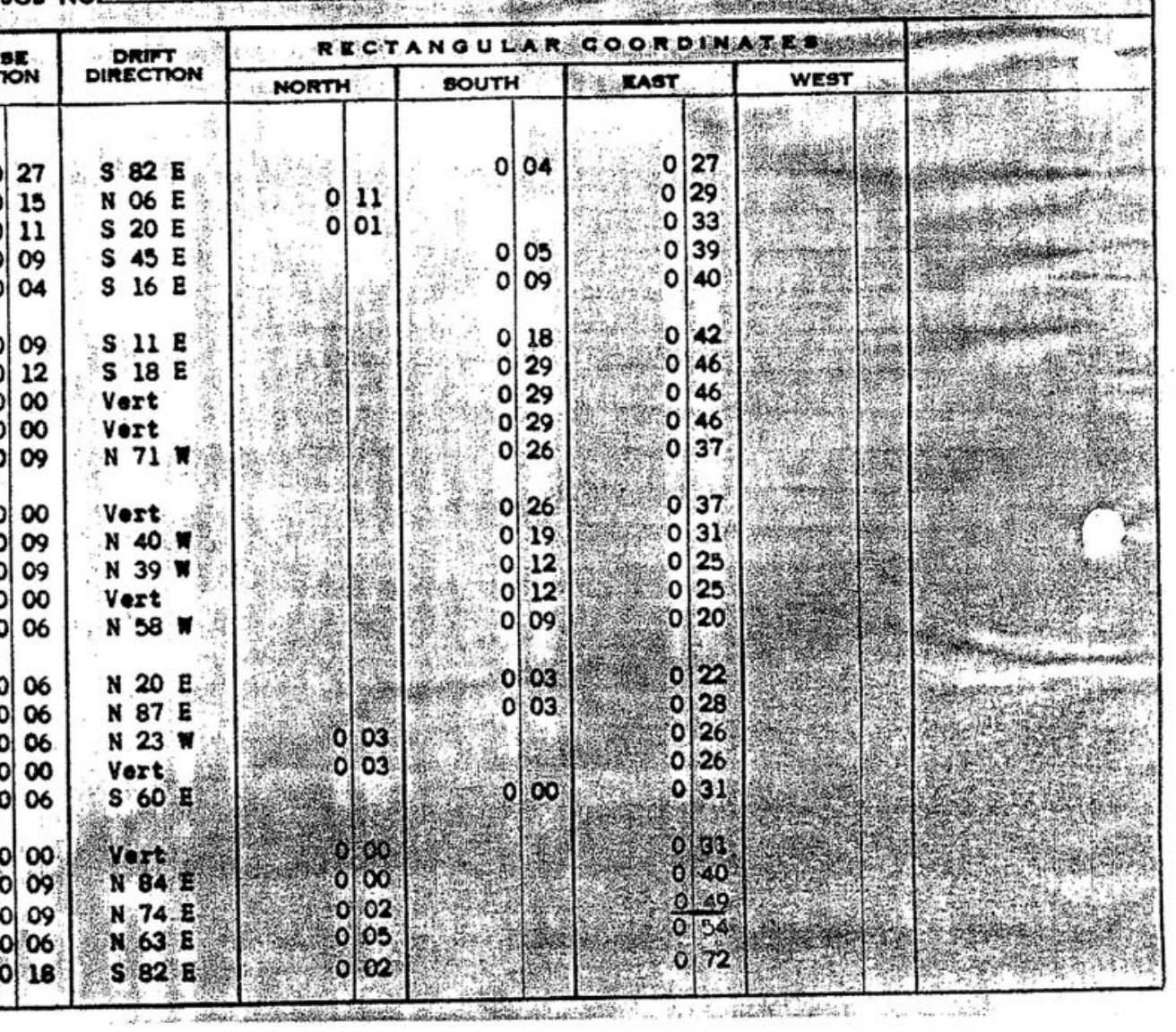




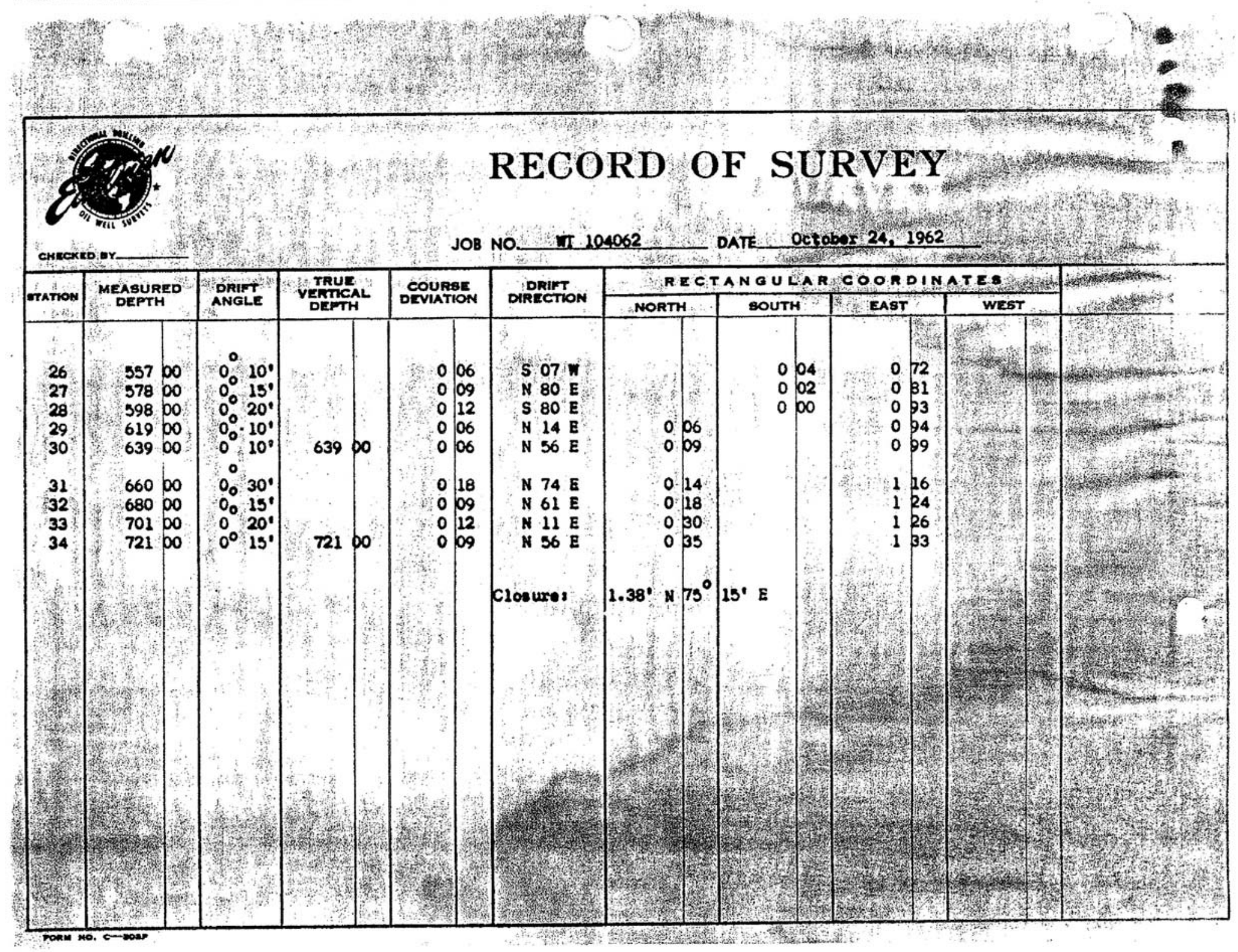




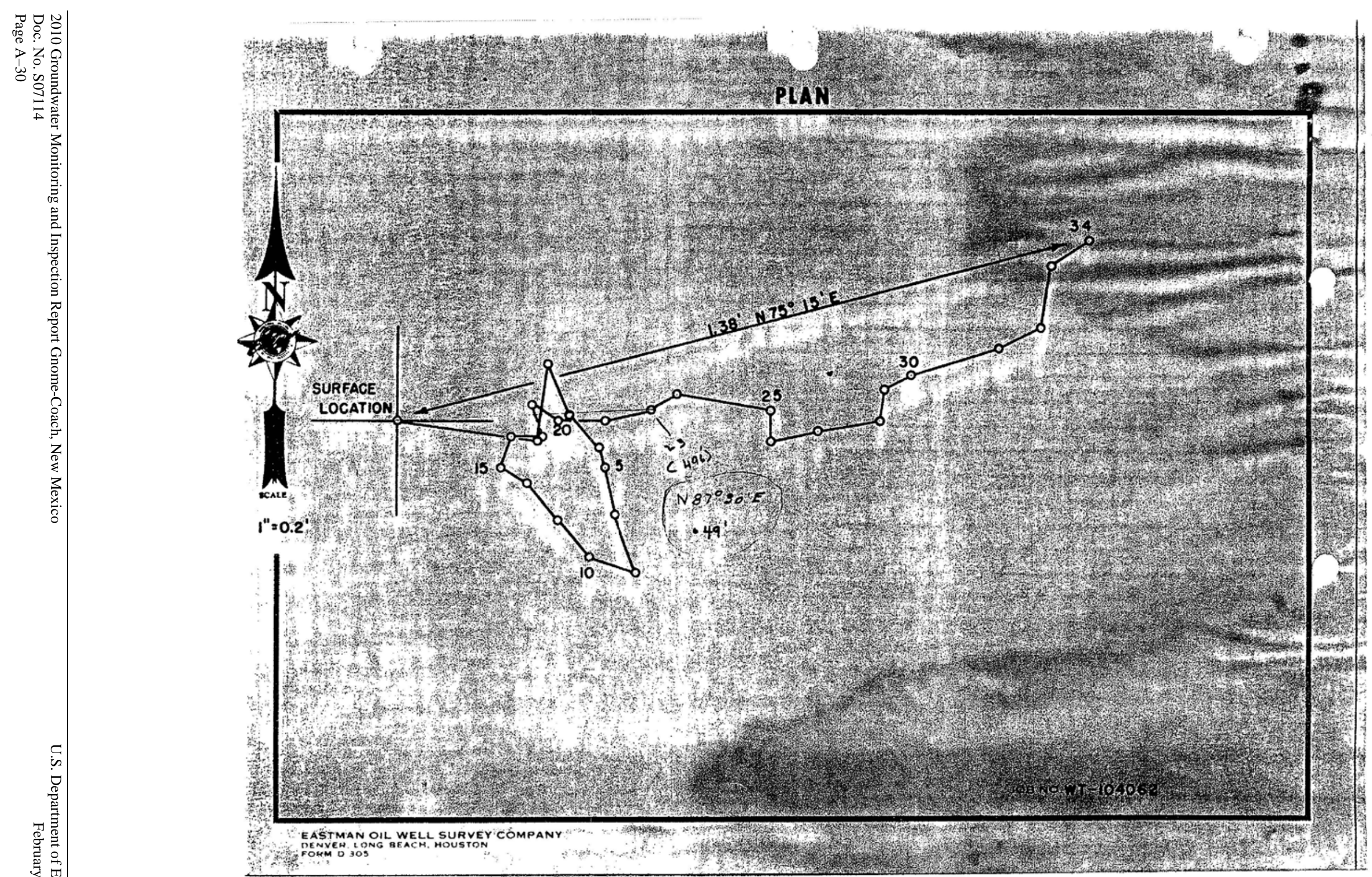




\section{Appendix B}

\section{Well Concentration Plots}


This page intentionally left blank 


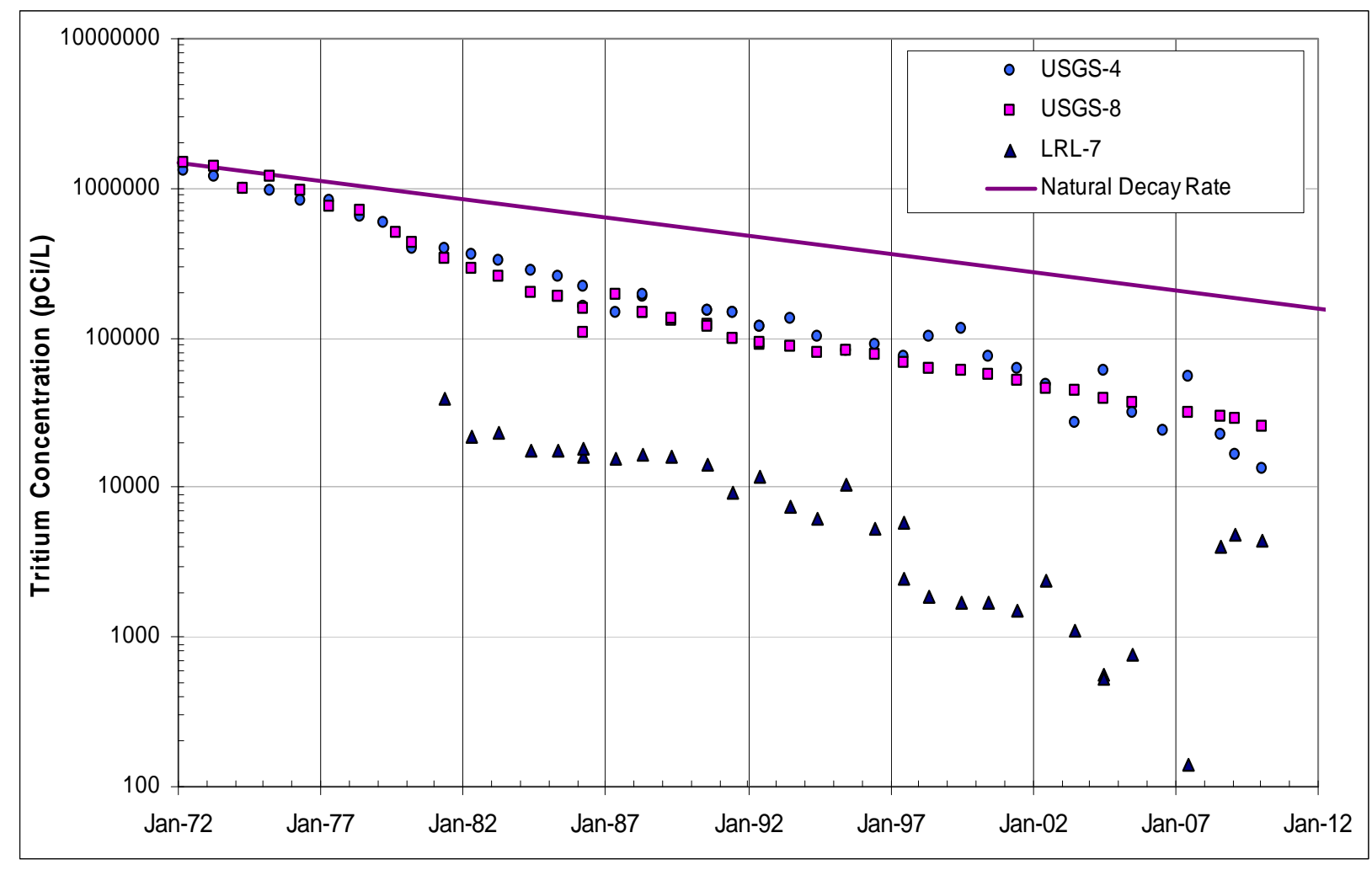

Chart 1. Tritium Concentrations at Wells USGS-4, USGS-8, and LRL-7

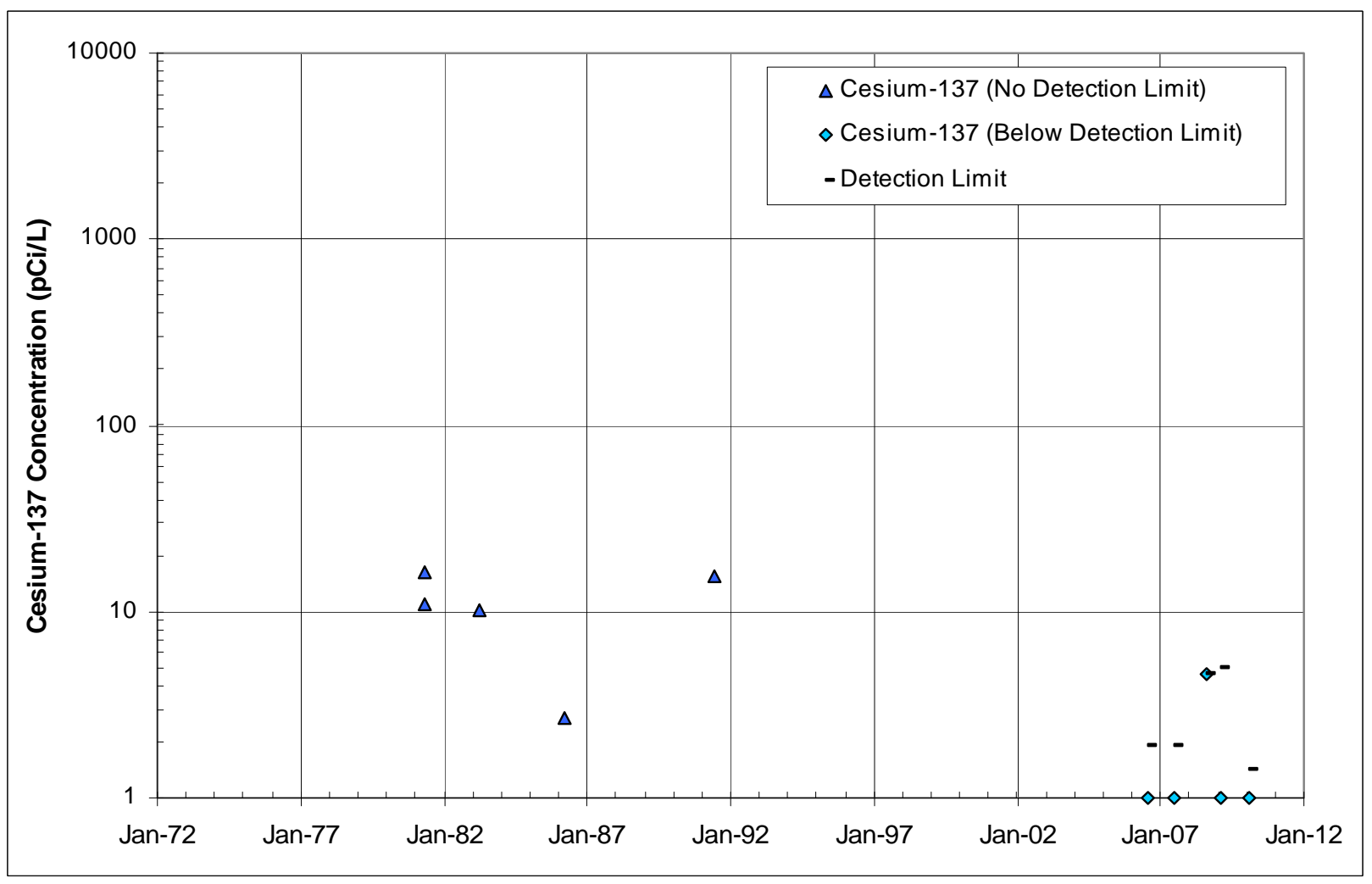

Chart 2. Cesium-137 Concentrations at Well USGS-4 


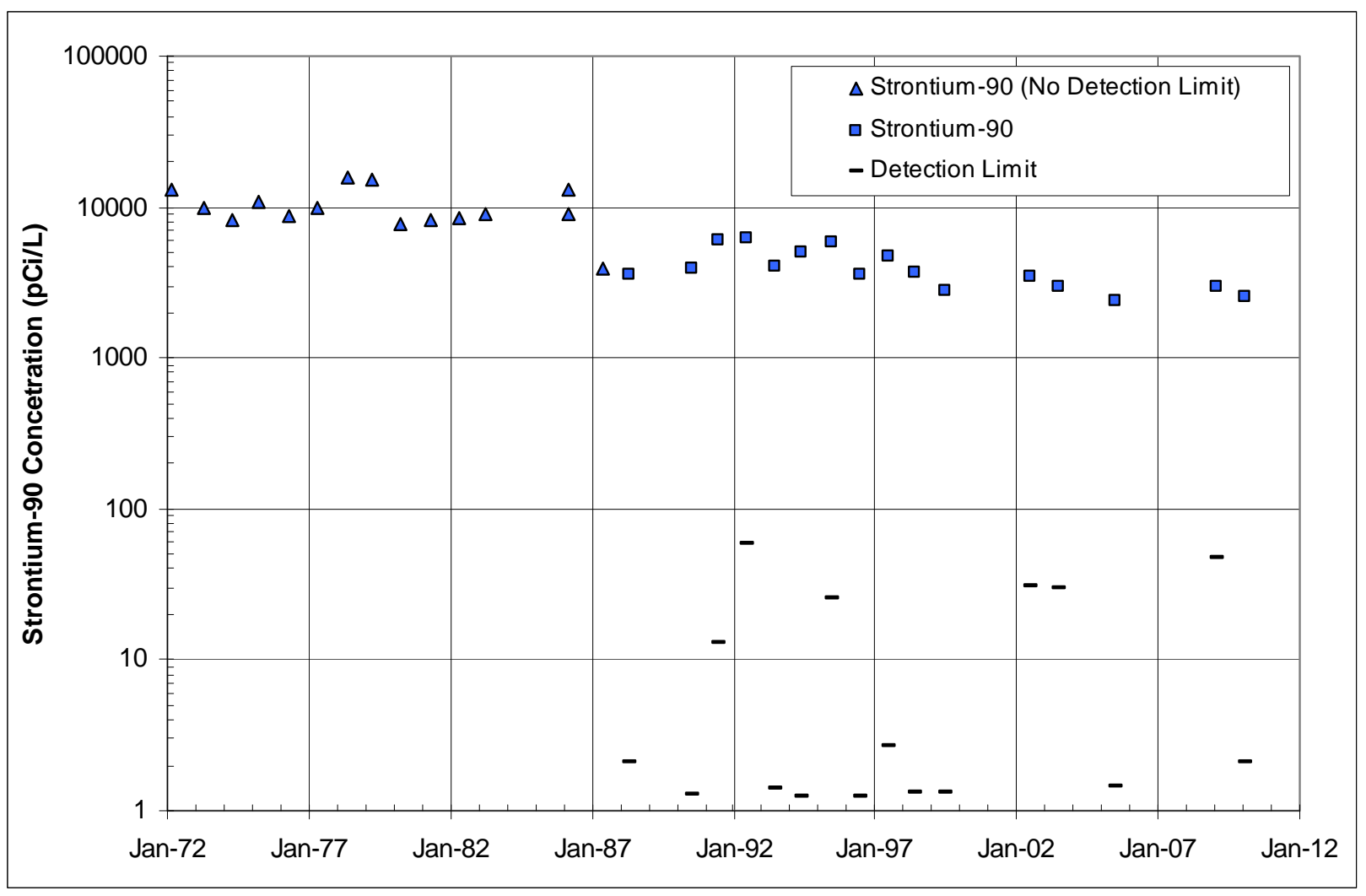

Chart 3. Strontium-90 Concentrations at Well USGS-4

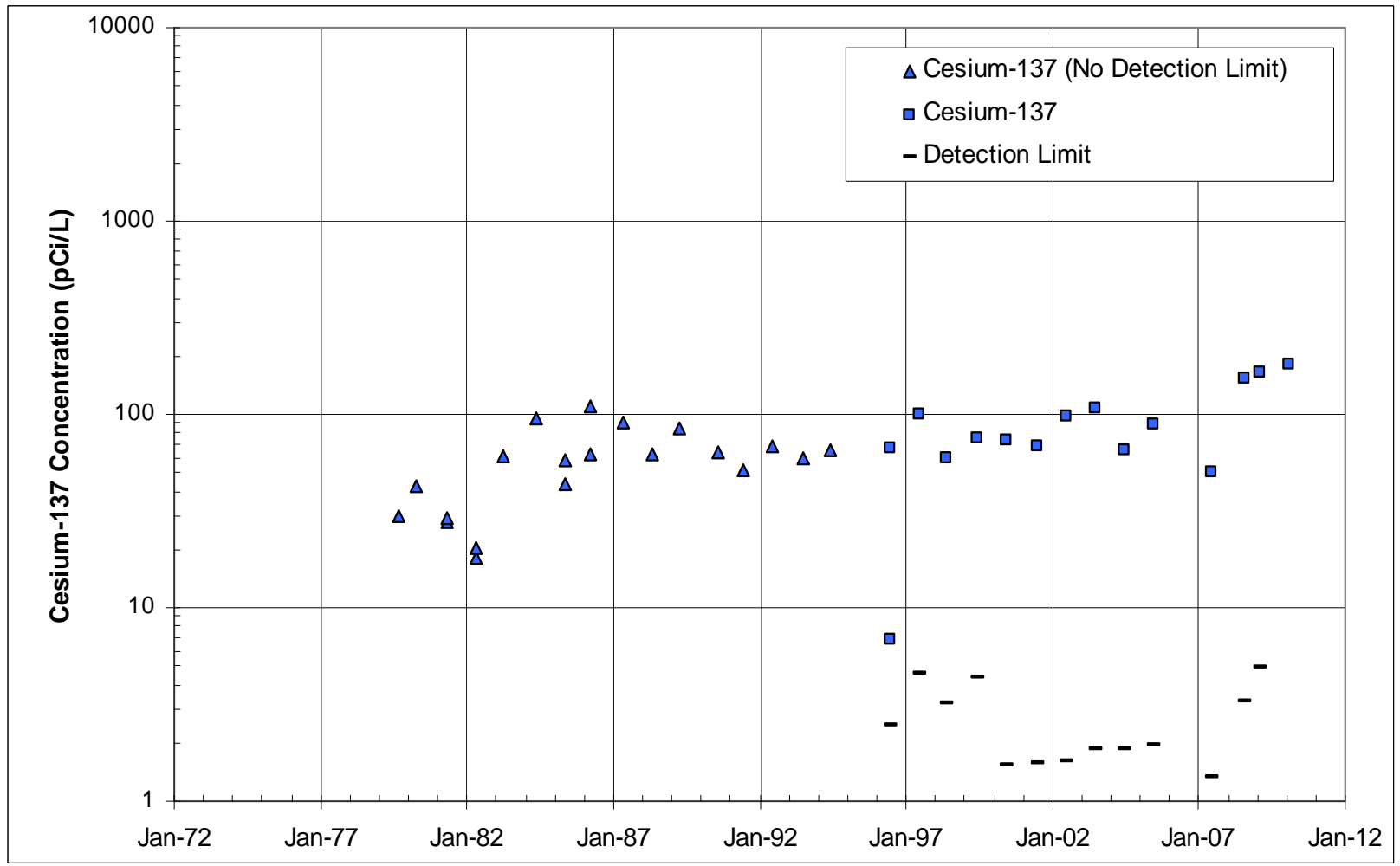

Chart 4. Cesium-137 Concentrations at Well USGS-8 


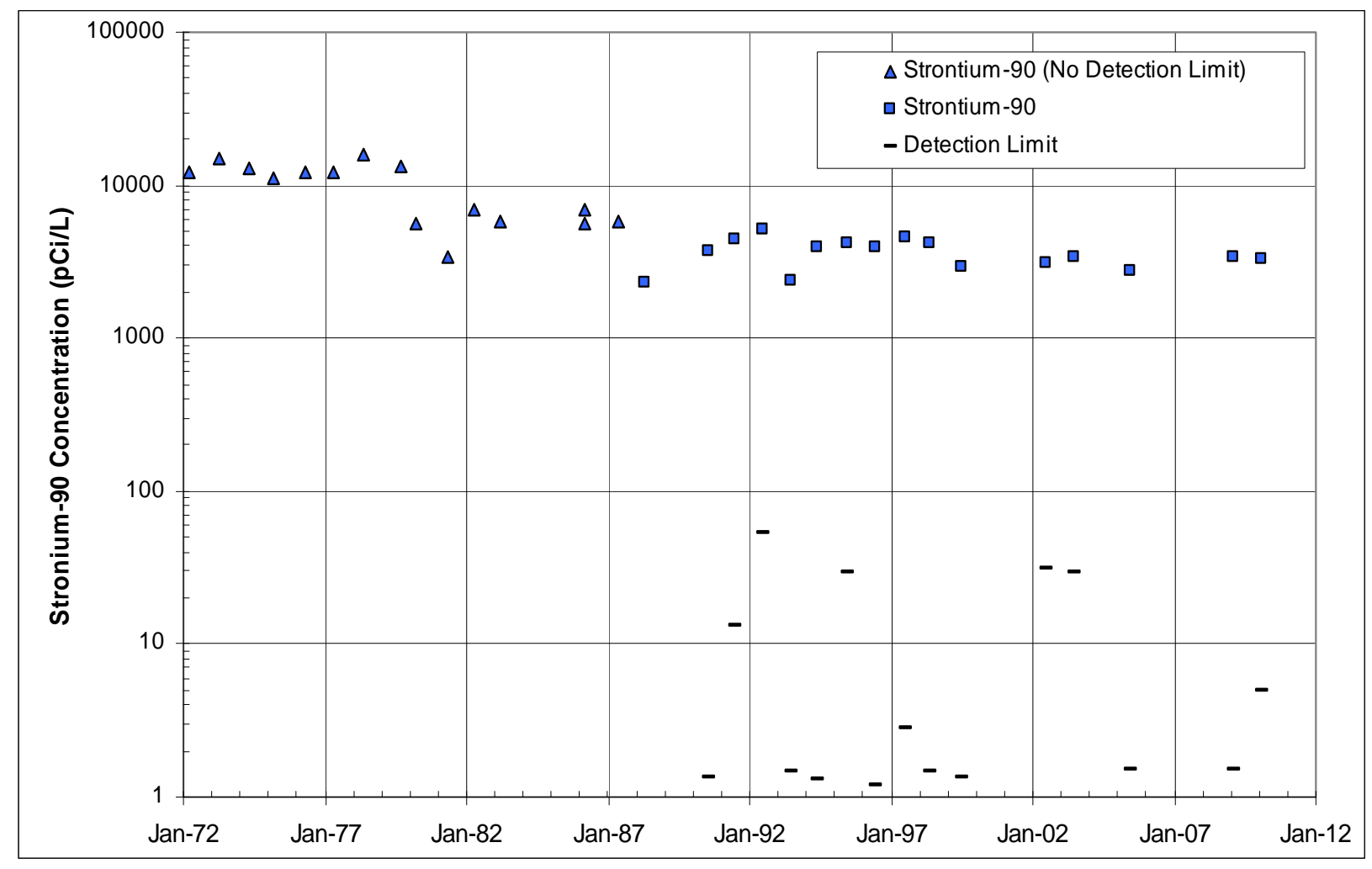

Chart 5. Strontium-90 Concentration at Well USGS-8

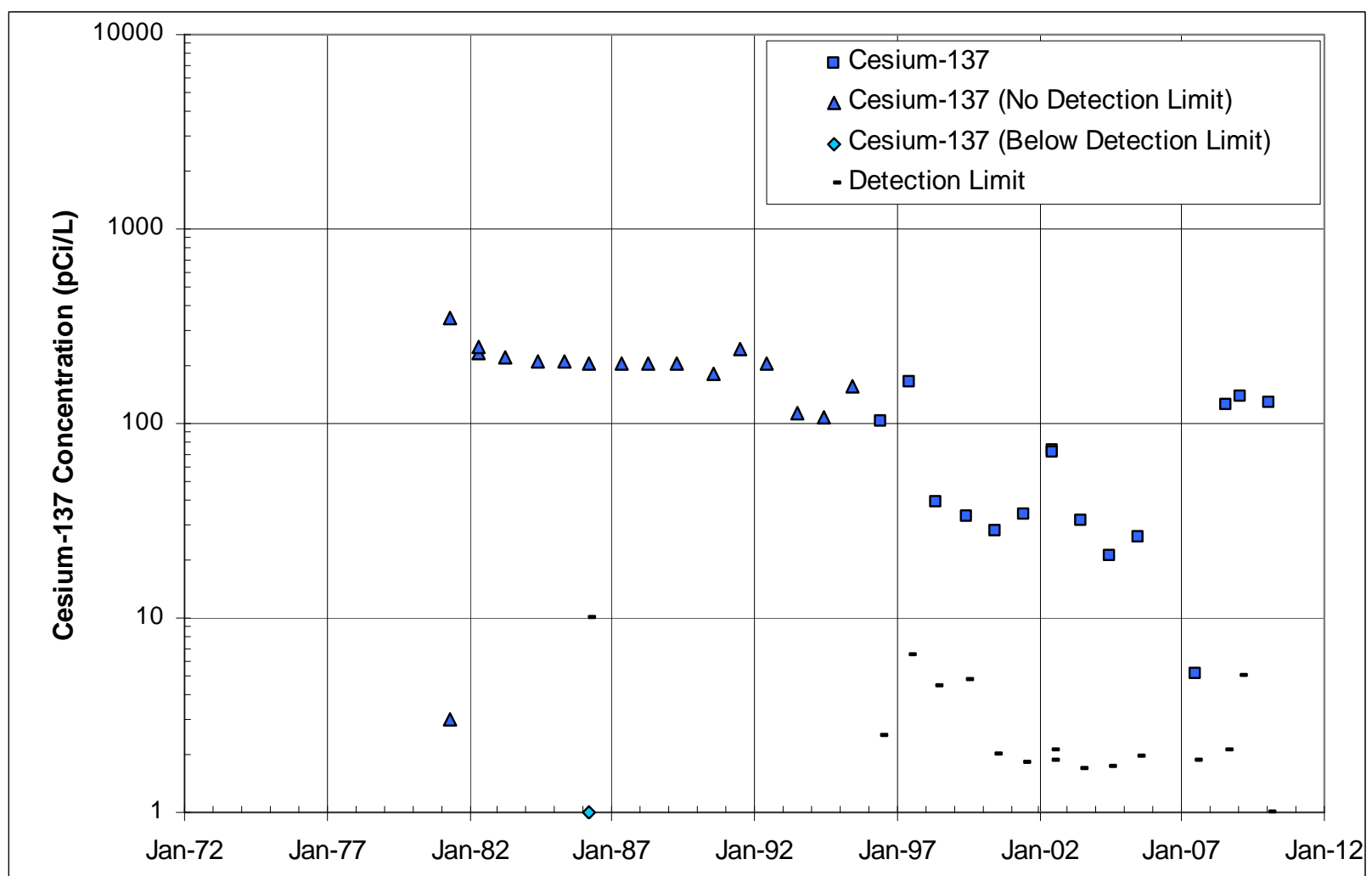

Chart 6. Cesium-137 Concentration at Well LRL-7 


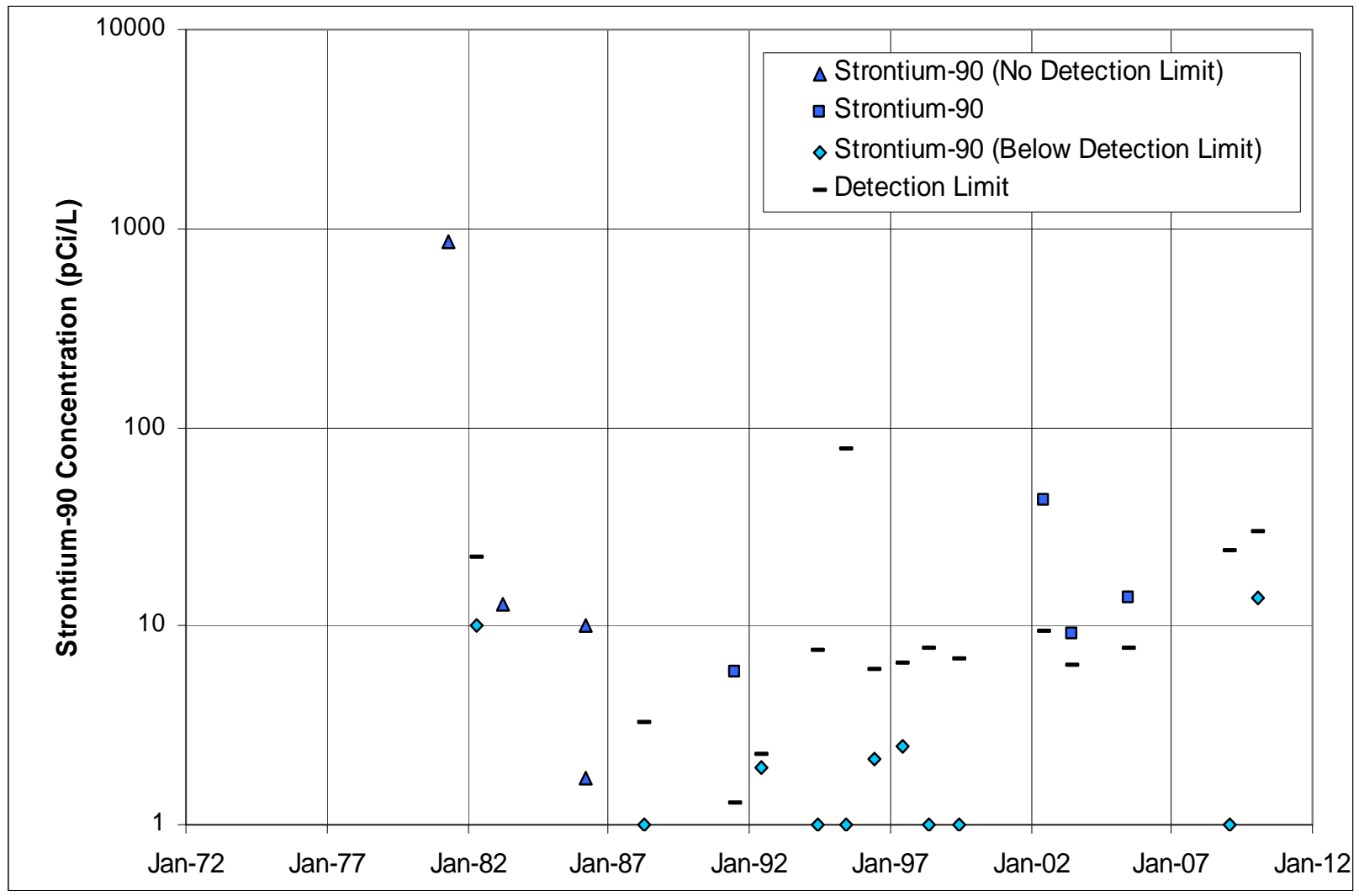

Chart 7. Strontium-90 Concentrations at Well LRL-7 


\title{
Distribution List
}

\author{
$\underline{\text { Copies }}$ \\ 1 (Uncontrolled) \\ U.S. Department of Energy \\ National Nuclear Security Administration \\ Nevada Site Office \\ Technical Library \\ P.O. Box 98518, M/S 505 \\ Las Vegas, NV 89193-8518 \\ 702-295-3521 \\ U.S. Department of Energy \\ 1 (Uncontrolled, electronic copy) \\ Office of Scientific and Technical Information \\ P.O. Box 62 \\ Oak Ridge, TN 37831-0062 \\ 865-576-8401 \\ Southern Nevada Public Reading Facility \\ c/o Nuclear Testing Archive \\ P.O. Box 98521, M/S 400 \\ Las Vegas, NV 89193-8521 \\ New Mexico Environment Department - GWQB \\ Ross Muir \\ Environmental Scientist \\ 1190 St. Francis Drive \\ Sante Fe, NM 87505-5469 \\ Department of Energy - EM \\ Daniel Ferguson \\ Site Manager- WIPP \\ 4100 National Parks Highway \\ Carlsbad, NM 88220 \\ Bureau of Land Management \\ 1 (Uncontrolled) \\ 2 (Uncontrolled, electronic copies) \\ Steve Daly \\ Soil Conservationist \\ 620 E. Greene Street \\ Carlsbad, NM 88220 \\ 1 (Uncontrolled, electronic copy) \\ 1 (Uncontrolled) \\ (Uncontrolled, electronic copy)
}


This page intentionally left blank 